
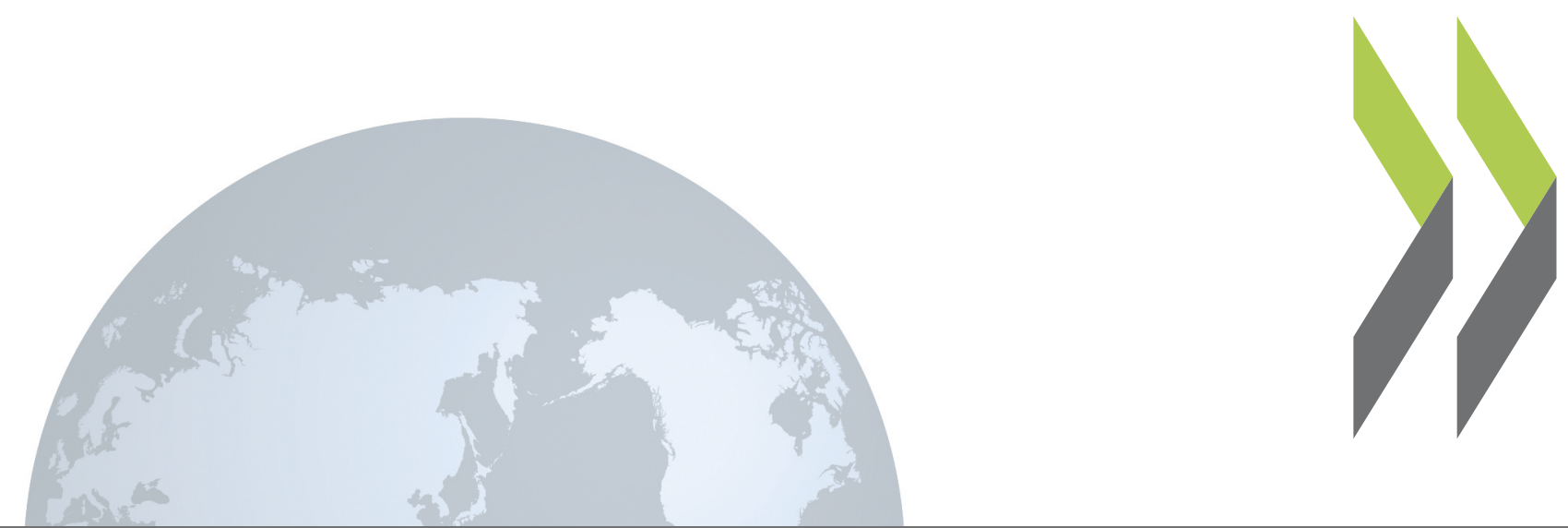

SIGMA Papers No. 17

\title{
Administrative Procedures
}

and the Supervision of Administration in Hungary, Poland, Bulgaria, Estonia and Albania

\section{OECD}


ADMINISTRATIVE PROCEDURES AND THE SUPERVISION OF ADMINISTRATION IN HUNGARY, POLAND, BULGARIA, ESTONIA AND ALBANIA

SIGMA PAPERS: No. 17

ORGANISATION FOR ECONOMIC CO-OPERATION AND DEVELOPMENT

Paris 


\section{THE SIGMA PROGRAMME}

SIGMA -- Support for Improvement in Governance and Management in Central and Eastern European Countries -is a joint initiative of the OECD Centre for Co-operation with the Economies in Transition and the European Union's Phare Programme. The initiative supports public administration reform efforts in thirteen countries in transition, and is financed mostly by Phare.

The Organisation for Economic Co-operation and Development is an intergovernmental organisation of 29 democracies with advanced market economies. The Centre channels the Organisation's advice and assistance over a wide range of economic issues to reforming countries in Central and Eastern Europe and the former Soviet Union. Phare provides grant financing to support its partner countries in Central and Eastern Europe to the stage where they are ready to assume the obligations of membership of the European Union.

Phare and SIGMA serve the same countries: Albania, Bosnia-Herzegovina, Bulgaria, the Czech Republic, Estonia, the Former Yugoslav Republic of Macedonia, Hungary, Latvia, Lithuania, Poland, Romania, Slovakia and Slovenia.

Established in 1992, SIGMA works within the OECD's Public Management Service, which provides information and expert analysis on public management to policy-makers and facilitates contact and exchange of experience amongst public sector managers. SIGMA offers beneficiary countries access to a network of experienced public administrators, comparative information, and technical knowledge connected with the Public Management Service.

SIGMA aims to:

- $\quad$ assist beneficiary countries in their search for good governance to improve administrative efficiency and promote adherence of public sector staff to democratic values, ethics and respect of the rule of law;

- help build up indigenous capacities at the central governmental level to face the challenges of internationalisation and of European Union integration plans; and

- $\quad$ support initiatives of the European Union and other donors to assist beneficiary countries in public administration reform and contribute to co-ordination of donor activities.

Throughout its work, the initiative places a high priority on facilitating co-operation among governments. This practice includes providing logistical support to the formation of networks of public administration practitioners in Central and Eastern Europe, and between these practitioners and their counterparts in other democracies.

SIGMA works in five technical areas: Administrative Reform and National Strategies, Management of Policy-making, Expenditure Management, Management of the Public Service, and Administrative Oversight. In addition, an Information Services Unit disseminates published and on-line materials on public management topics.

\section{Copyright OECD, 1997}

Applications for permission to reproduce or translate all or part of this material should be made to: Head of Publications Service, OECD, 2 rue André-Pascal, 75775 Paris Cedex 16, France.

Views expressed in this publication do not represent official views of the Commission, OECD Member countries, or the central and eastern European countries participating in the Programme. 


\title{
FOREWORD
}

SIGMA is publishing this report to make more widely available comparative information on administrative law and administrative supervision in central and eastern European countries, and to highlight certain relationships with developments in these areas in Western Europe. Although each country has its own history and traditions in approaching these matters, there is at the same time emerging a common and widely accepted model of how they should be managed in democratic states. This report should be of particular interest to civil servants, government officials, parliamentarians and others with an interest in the development of administrative procedures and oversight institutions.

Numerous individuals from the five countries studied contributed to the project leading to this publication. Some provided information which otherwise would not have been available; others agreed to be interviewed and gave generously of their time; while others still read and offered comments on drafts of the report. This group includes officials, lawyers, parliamentarians, judges and scholars from many parts of Central and Eastern Europe. They were very helpful in explaining the sometimes great difference between what laws say and how they operate in practice.

Professor Denis Galligan, Director, University of Oxford's Centre for Socio-Legal Studies (Wolfson College), performed the research and wrote this report. The opinions expressed in the report are his. Ms. Ágnes Munkácsi, a lawyer from the Hungarian Parliament on an OECD training programme to the SIGMA Secretariat, served as project co-ordinator and made important contributions to the project. It should be borne in mind that laws and practices in the region are changing rapidly and that changes have occurred in some of the areas discussed here. The text is based on information available through October 1996.

Staffan Synnerström, Senior Counsellor for the Management of the Public Service at the SIGMA Secretariat, launched the project in early 1996 and oversaw its progress. Upon joining SIGMA later that year, Kjell Larsson, Senior Counsellor for Administrative Control, assumed this responsibility. Larsson is also responsible for organising forthcoming workshops which will use this report as a base. He may be contacted at the SIGMA Secretariat for more details about the subjects dealt with in this report, and about SIGMA work in the administrative oversight field.

Administrative Procedures and the Supervision of the Administration in Hungary, Poland, Bulgaria, Estonia and Albania is also available in French under the title La procédure administrative et le contrôle de l'administration en Hongrie, Pologne, Bulgarie, Estonie et Albanie.

This report is published on the responsibility of the Secretary-General of the OECD.

\author{
SIGMA-OECD \\ 2, rue André-Pascal \\ 75775 Paris Cedex 16, France \\ Tel (33.1) 45.24.79.00 or 45.24.13.94 \\ Fax (33.1) 45.24.13.00 \\ e-mail: sigma.contact@oecd.org \\ http://www.oecd.org/puma/sigmaweb
}




\section{EXECUTIVE SUMMARY}

This SIGMA Paper addresses administrative law and administrative institutions in Hungary, Poland, Bulgaria, Estonia and Albania. The countries represent different geographical, cultural and historical groupings. The paper consists of two parts. The first examines administrative procedures in the countries mentioned, the second addresses the various forms of judicial and non-judicial supervision of the countries' administrations. Both parts aim to describe the position in each country studied, and to identify areas inviting further consideration by governments.

All countries in Central and Eastern Europe recognise that the building — or rebuilding, as the case may be - of a professional and stable public administration is a vital element in the creation of a modern, democratic society. The fulfilment of that objective depends in part on creating suitable administrative institutions within which the plans of government may be implemented in an effective and economical manner.

While the attainment of the general objective requires long-term planning and the commitment of substantial resources, it also should be borne in mind that administrative government has a legal dimension. Three aspects of this legal dimension include: i) the administration should be conducted within a framework of law; ii) the relationship between the administrative authority and the citizen should not depend on the will or whim of the authority but ought to be mediated by legal principles; and iii) each administrative authority ought to be subject to supervision by other authorities.

Part I of the report identifies assumptions underlying procedures, outlines the background of the countries, and charts the changes that have occurred in recent years. This part concludes that the five countries studied, spread as they are across the region and with widely diverse backgrounds, are at very different stages of development of administrative law. Each has been engaged on a programme of reform to bring its system in line with a model of administrative procedure which has come to be accepted across Europe. Further, a certain tension exists between the procedural regimes of the communist period and those which are more suitable to a democratic, rule of law system.

Part II addresses not only judicial supervision, but also supervision provided by other bodies, including ombudsmen, inspectorates and special commissions, the prosecutor, and parliamentary committees. While judicial supervision by independent courts is a central plank in the reforms of all five countries, this is confined to matters of legality. The most suitable forms of supervision of the content and merits of administrative actions are more debatable and divergent views are expressed.

It is hoped that the report will prove of interest to officials, legislators and law reformers of the countries studied. Critical analysis offered in the text is intended to be helpful and constructive and should be read against a background of major accomplishments in most central and eastern European countries during the 1990s. 


\section{TABLE OF CONTENTS}

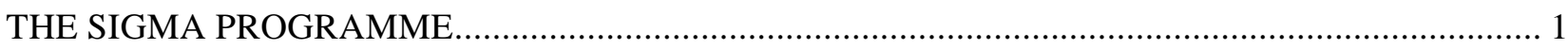

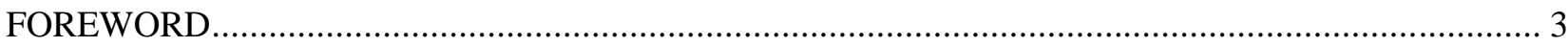

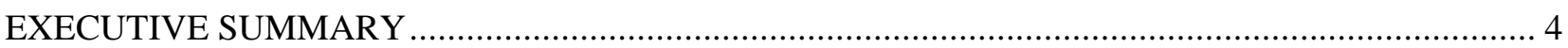

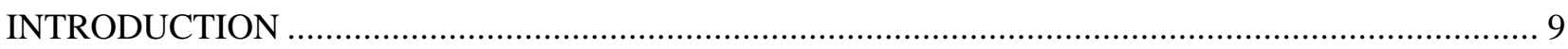

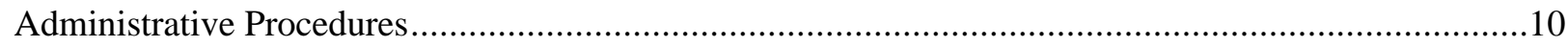

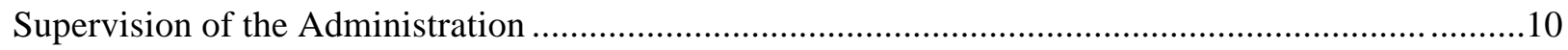

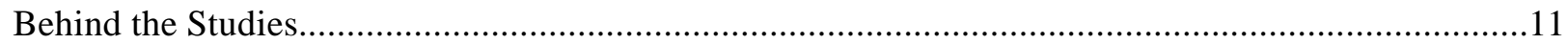

PART I: ADMINISTRATIVE PROCEDURES AND THE SUPERVISION OF THE ADMINISTRATION IN HUNGARY, POLAND, BULGARIA, ESTONIA AND ALBANIA .................12

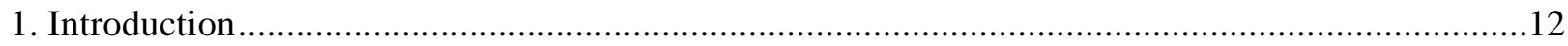

1.1. The Objectives of Administrative Law and Procedure …......................................................12

1.2. Administrative Law and Procedure in Central and Eastern Europe............................................15

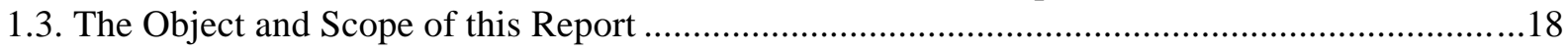

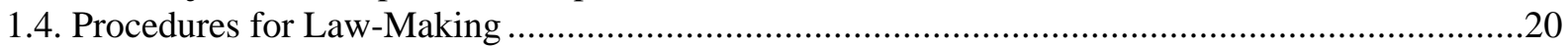

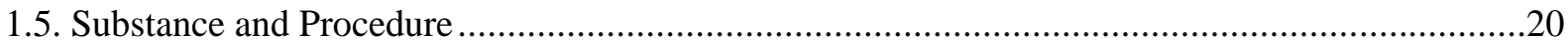

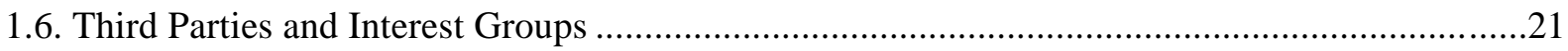

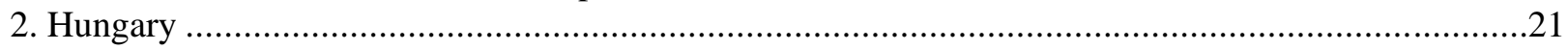

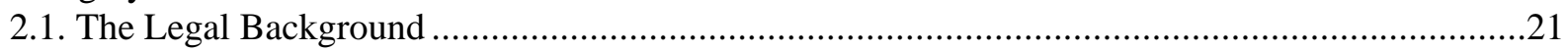

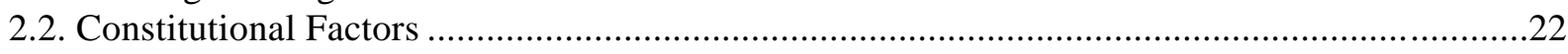

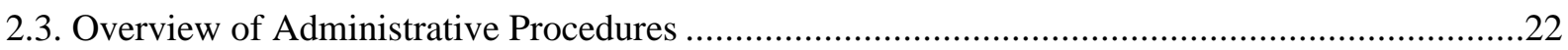

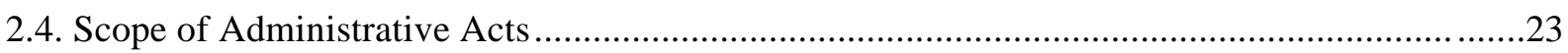

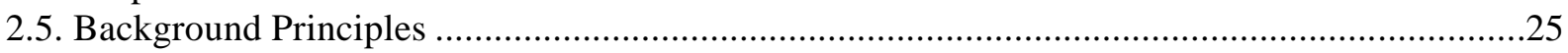

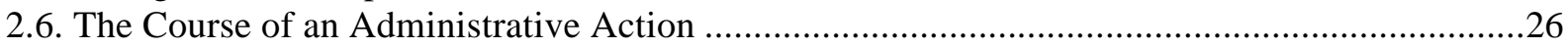

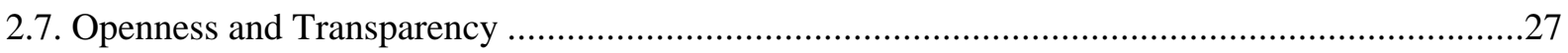

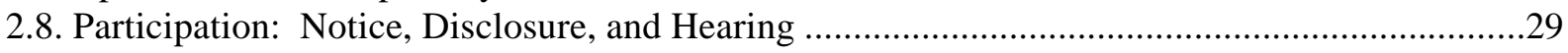

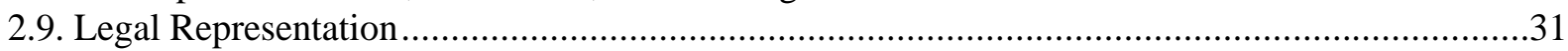

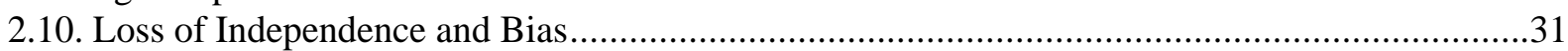

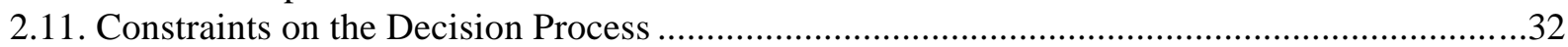

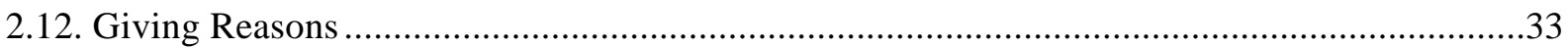

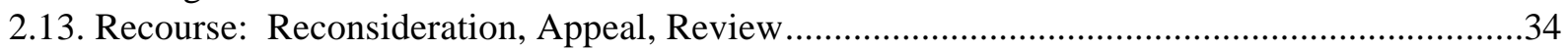

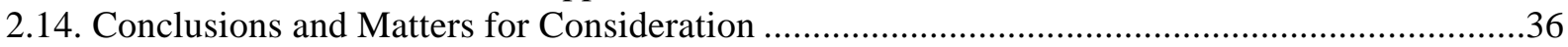

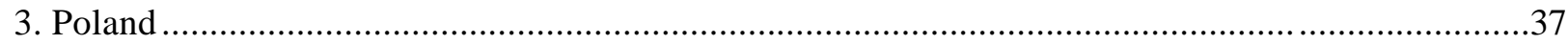

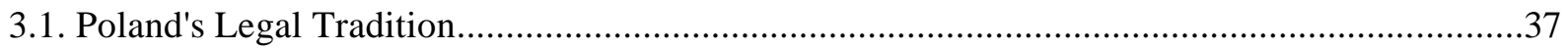

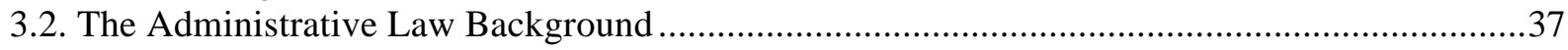

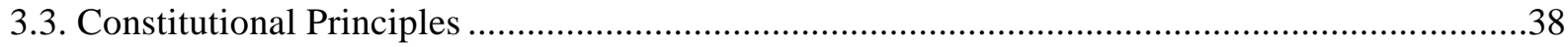

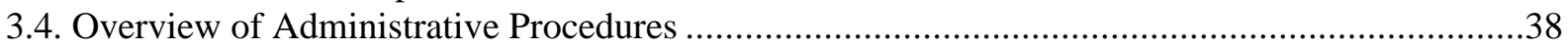

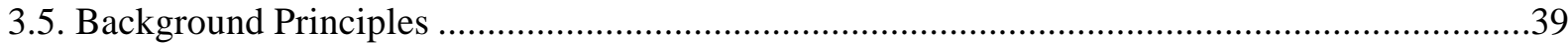


3.6. Scope of Administrative Action

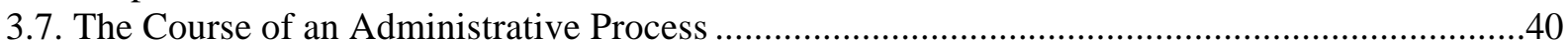

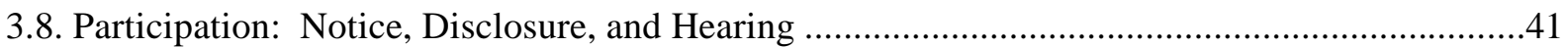

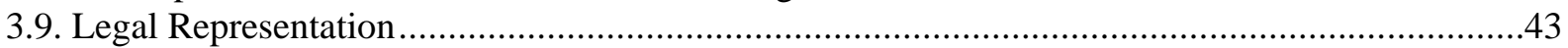

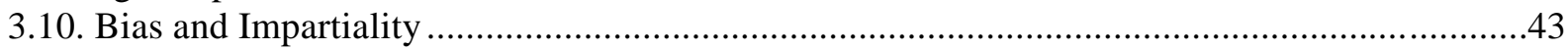

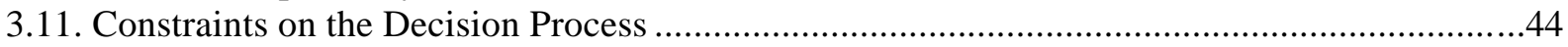

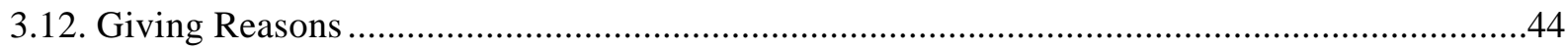

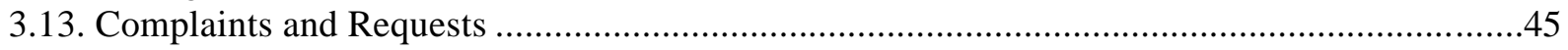

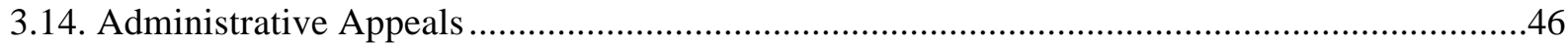

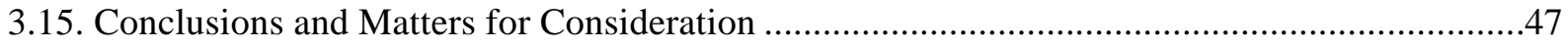

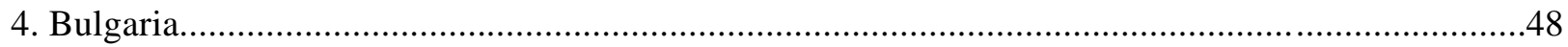

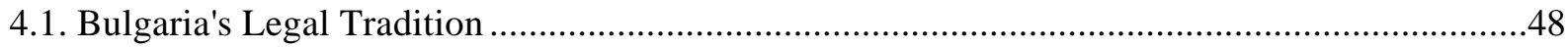

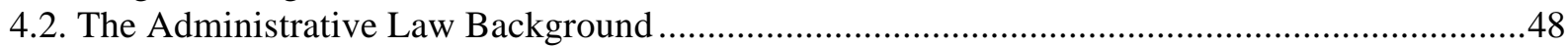

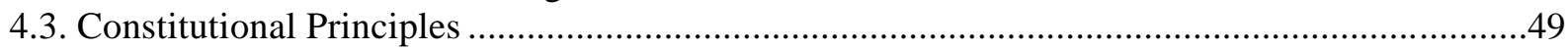

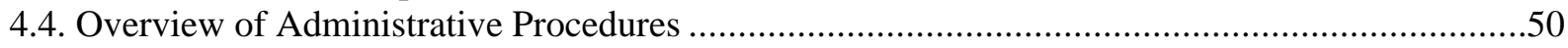

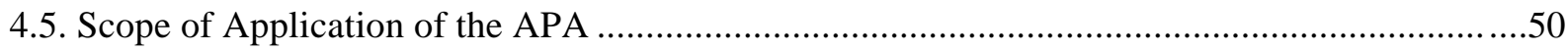

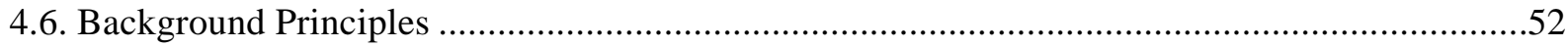

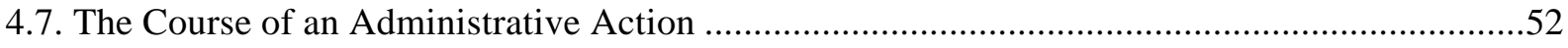

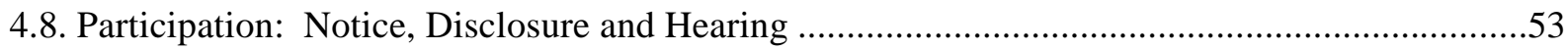

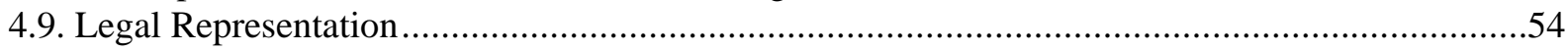

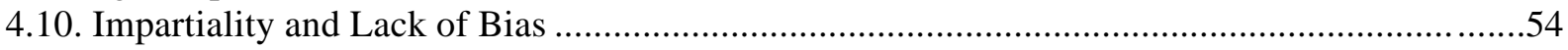

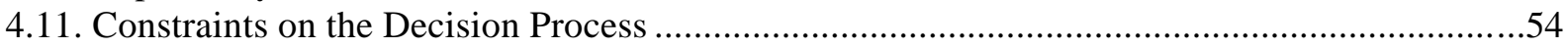

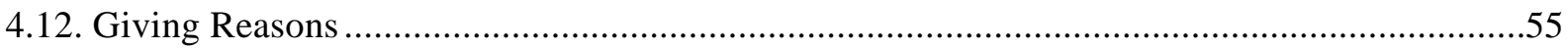

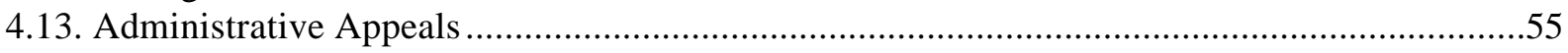

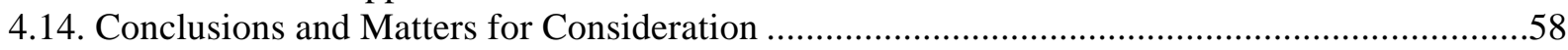

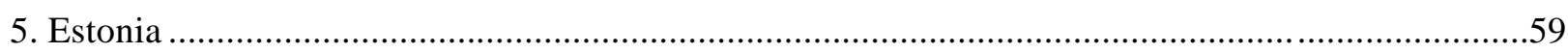

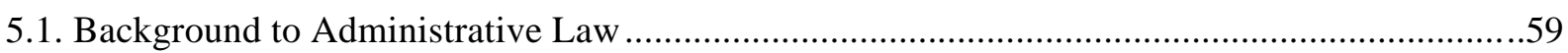

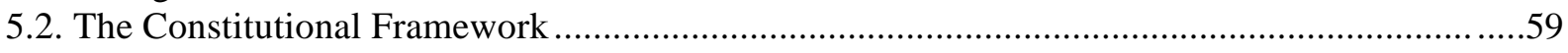

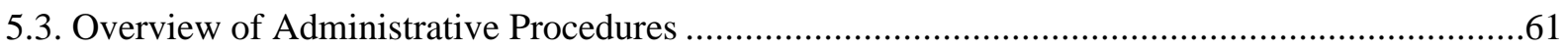

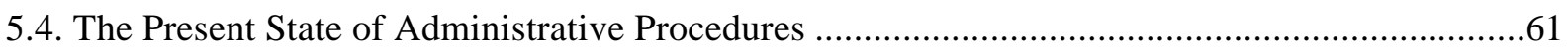

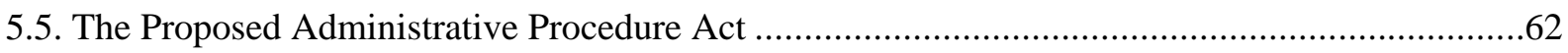

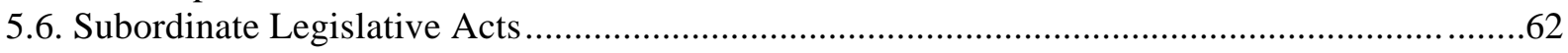

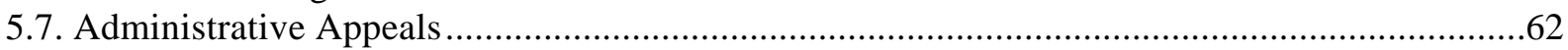

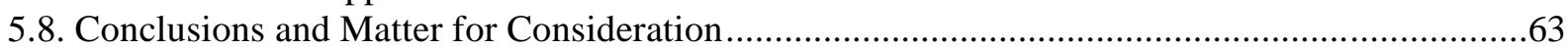

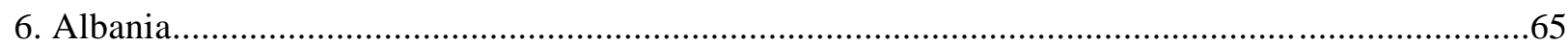

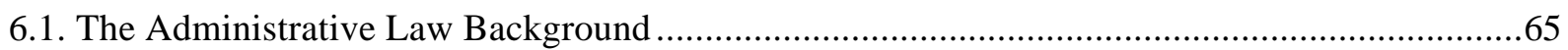

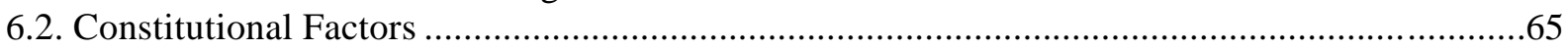

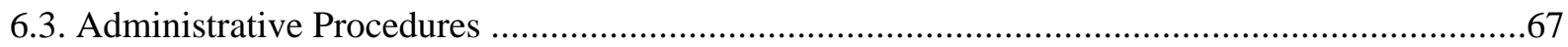

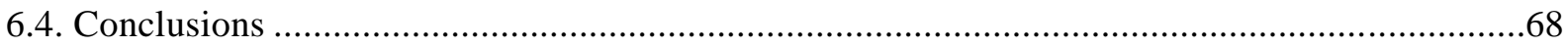

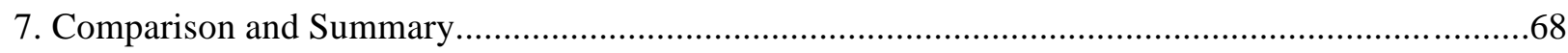

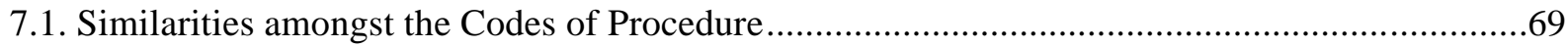

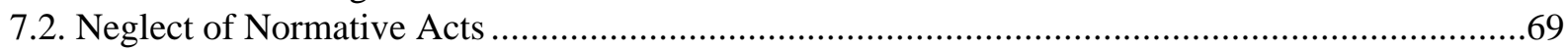

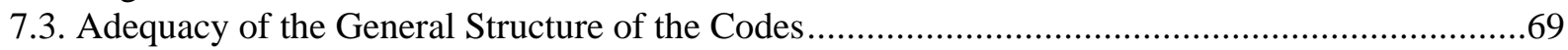

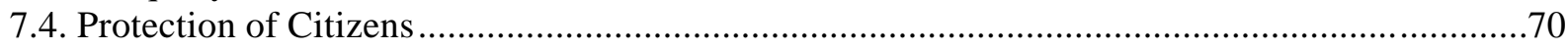

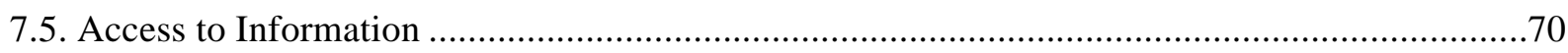

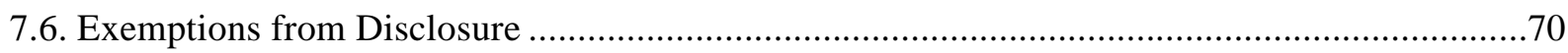

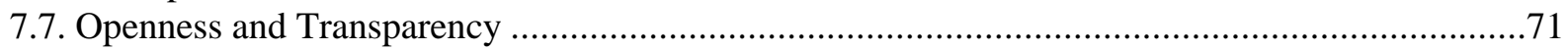

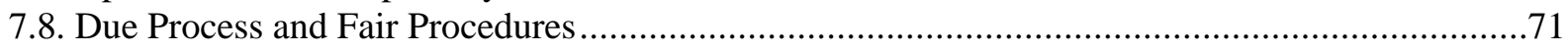

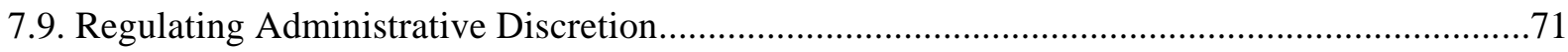

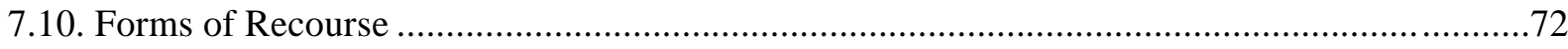


PART II: JUDICIAL AND NON-JUDICIAL SUPERVISION OF ADMINISTRATIVE PROCESSES..74

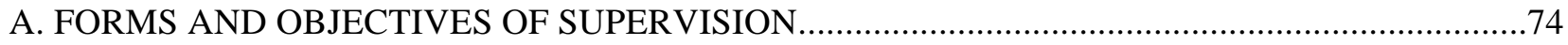

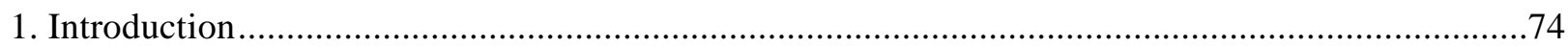

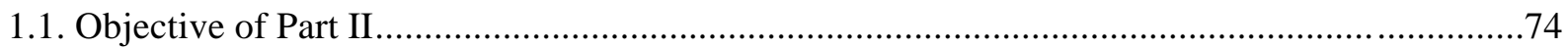

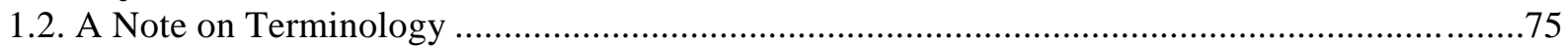

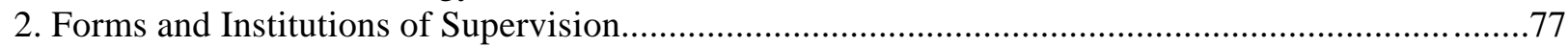

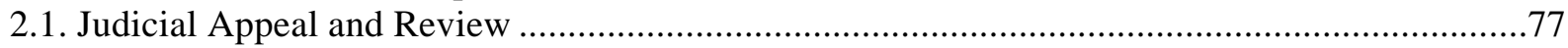

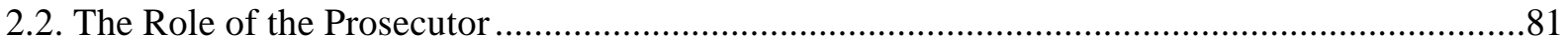

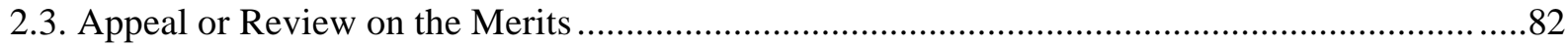

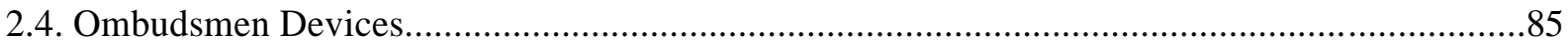

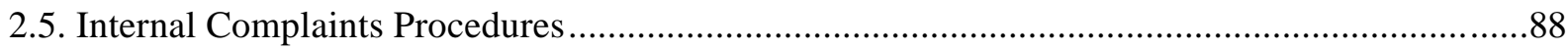

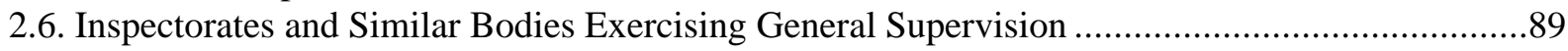

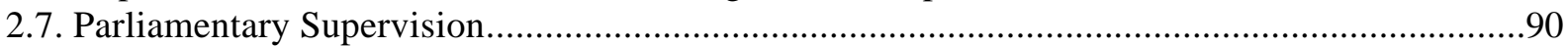

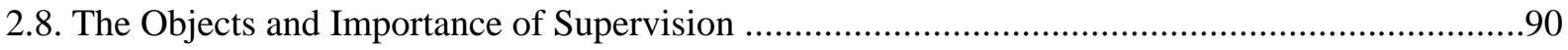

B. FORMS OF SUPERVISION IN HUNGARY, POLAND, BULGARIA, ESTONIA, AND ALBANIA92

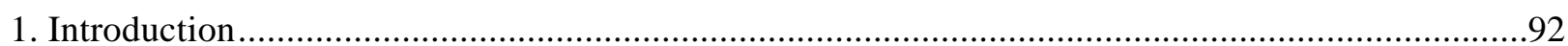

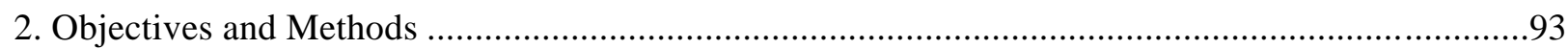

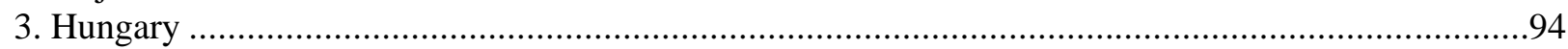

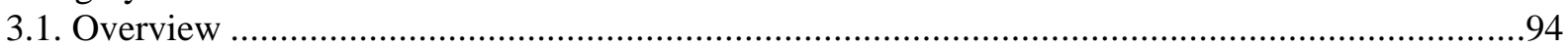

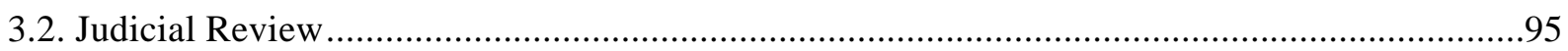

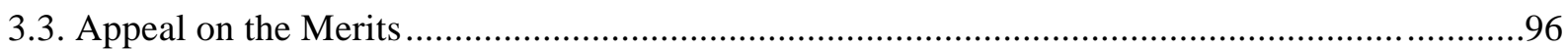

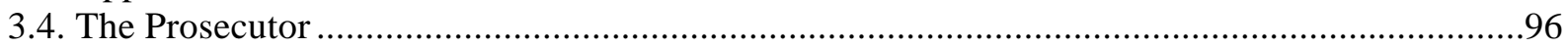

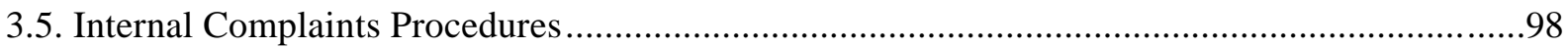

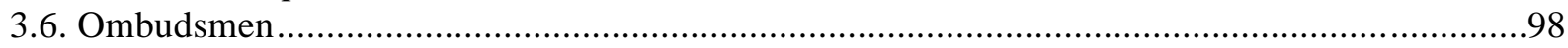

3.7. Inspectorates, Commissions, and other Forms of Special Supervision ....................................100

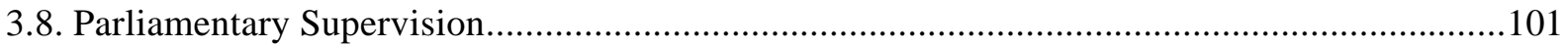

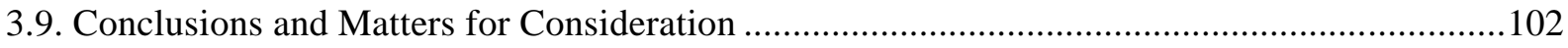

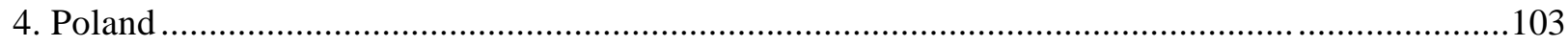

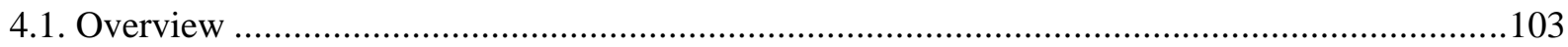

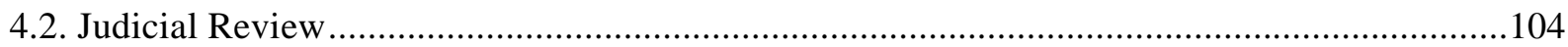

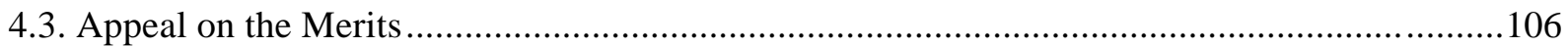

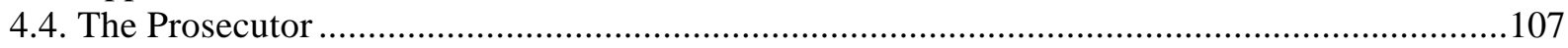

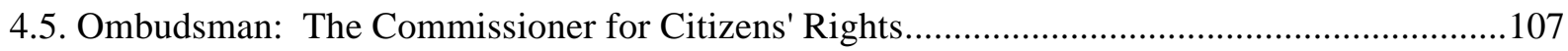

4.6. Inspectorates, Commissions, and Forms of Special Supervision …….......................................109

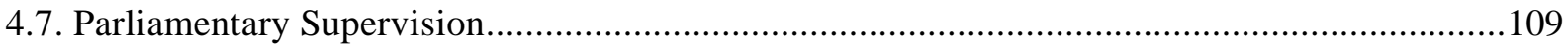

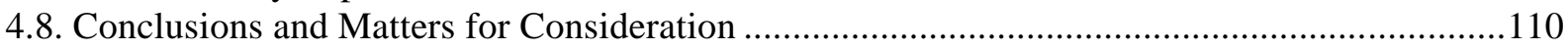

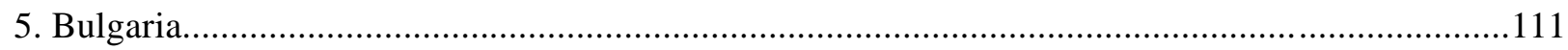

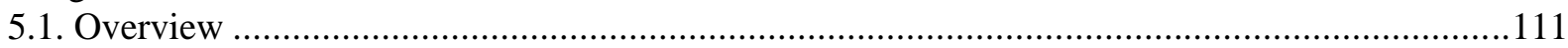

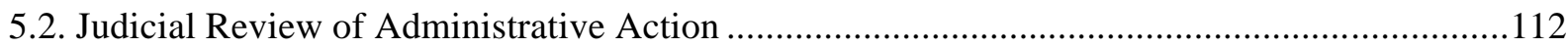

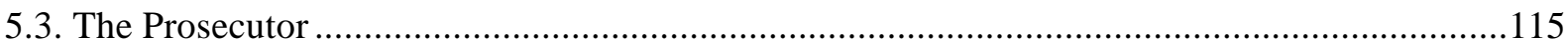

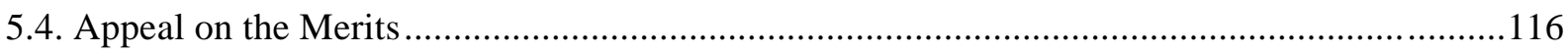

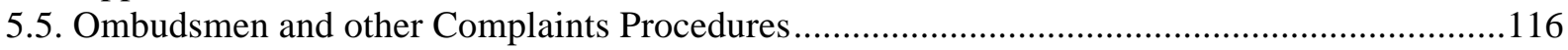

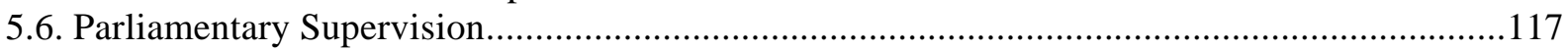

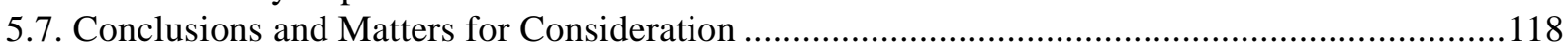

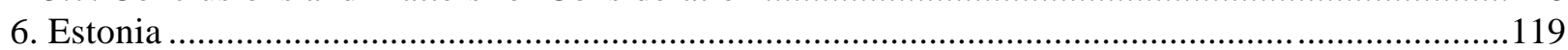

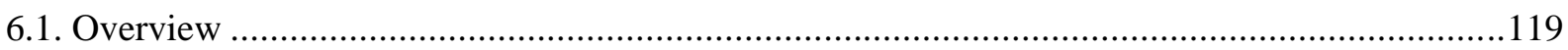

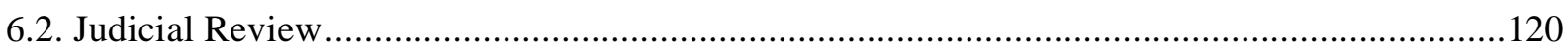


6.3. The Legal Chancellor

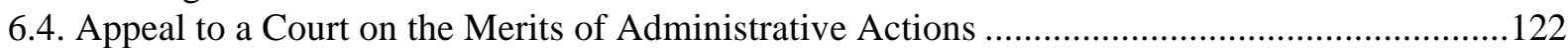

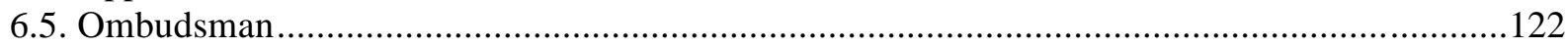

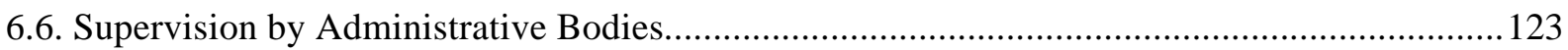

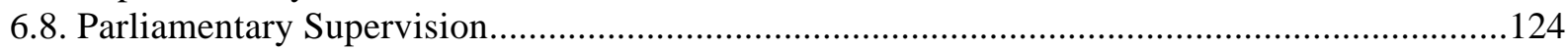

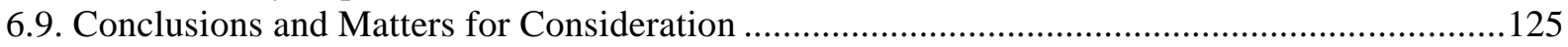

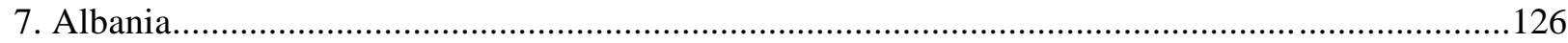

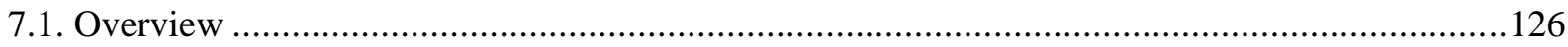

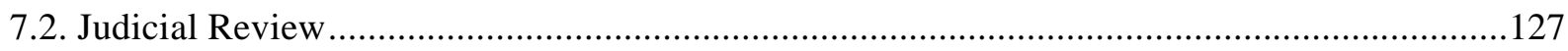

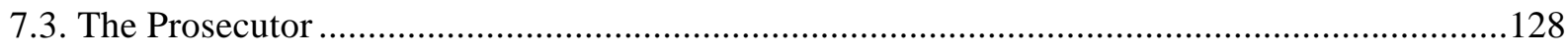

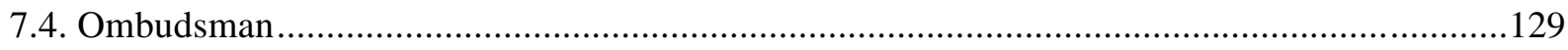

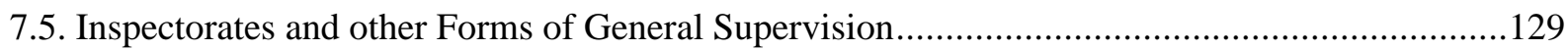

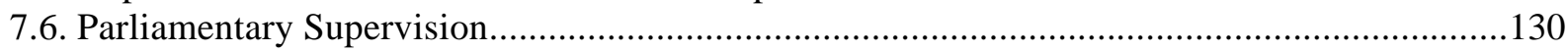

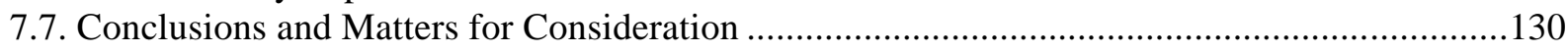

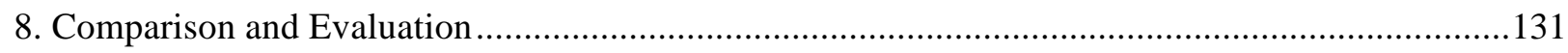

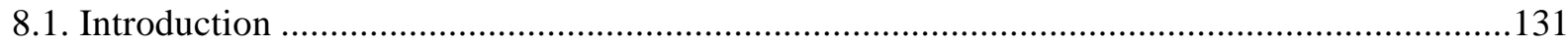

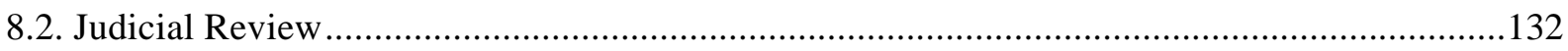

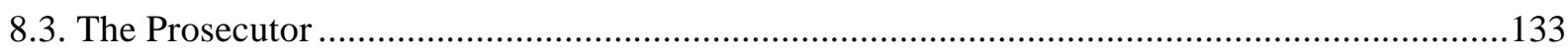

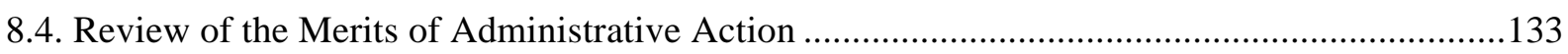

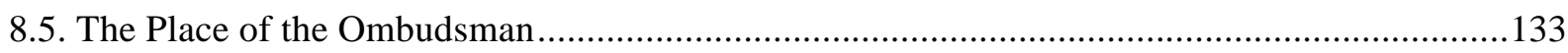

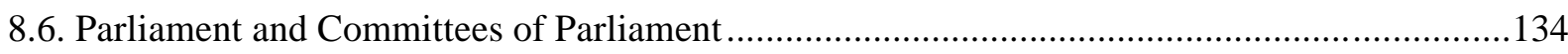




\section{INTRODUCTION}

The report which follows contains two separate but related studies of administrative law and administrative institutions in five countries of Central and Eastern Europe: Hungary, Poland, Bulgaria, Estonia and Albania. The studies were conducted on behalf of the SIGMA Programme. The report's first part examines administrative procedures in the countries mentioned, while the second part deals with the various forms of judicial and non-judicial supervision of the countries' administrations. The general objective in both parts is to describe the current position in each of the countries and to identify areas which invite further consideration by the respective countries. Such an undertaking inevitably means delving into the background of administrative law and administrative institutions in the region, even though that is done in a brief and superficial manner. It is also hard to avoid making some comparisons across the five countries, where the combination of shared experiences in recent history, with otherwise very different historical and cultural traditions, lends a special interest.

These are interesting and important times for administrative government in the central and eastern European countries. All countries recognise that the building or rebuilding, as the case may be, of a professional, stable, and effective public administration is a vital element in the creation of a modern, democratic society. The achievement of that objective depends fundamentally on having a well-trained civil service, which is independent and professional in its advice, but which is also subject to proper forms of accountability to the legal and political systems. The objective also depends on creating suitable administrative institutions within which the plans of government may be implemented in an effective and economical manner. That in turn depends on the provision of adequate resources and on the availability of civil servants with suitable expertise.

While the attainment of that general objective requires long-term planning and the commitment of substantial resources, it should not be forgotten that administrative government has a legal dimension. A fundamental principle is that administration should be conducted within a framework of law. Ministers, departments, and agencies of whatever kind should be created by law, should have their powers and duties clearly stated by law, and should be answerable when challenged to the law. The idea that ministers, departments, or agencies have inherent powers, or powers unlimited by law, or that they may exercise such powers as they think fit without regard to legal principles, is anathema to the basic principle of government under law.

A second important aspect of the legal dimension of administration is the relationship between the administrative authority on the one hand and the citizen on the other. That relationship should not depend on the will or whim of the authority but ought to be mediated by legal principles. The codes of administrative procedure, which are the subject of the first part of the report, provide one set of such principles.

The third aspect of the legal dimension which is of special importance turns on the idea that each administrative authority ought to be subject to supervision by other authorities, of both a judicial and non-judicial kind. Judicial supervision has a key role in ensuring that administration is conducted within the terms of the law and according to established legal principles. But other forms of supervision by non-judicial institutions, such as ombudsmen, special boards or inspectorates, and parliamentary 
committees, are also of great importance in maintaining good quality decision-making, which is also open, transparent, and fair. Whether these legal dimensions are respected in practice is very much linked to the quality and training of both those responsible for primary administration and those charged with supervising it; but however imperfect the legal dimension may be in practice, it is an essential component in creating a legitimate administrative service.

\section{Administrative Procedures}

This report examines two aspects of the legal dimension. In the first part, the administrative procedures of each of the five countries are analysed. That means identifying the assumptions underlying the procedures, outlining the background in each of the countries, and charting the changes that have occurred in recent years. Amongst the various conclusions that are drawn, the main ones may be briefly noted here.

The first point that emerges is that the five countries studied, spread as they are across the region and with widely diverse backgrounds, are at very different stages of development of administrative law and, at the more particular level, of administrative procedures. While countries such as Hungary and Poland have strong traditions in this area which continued during the communist period, other countries such as Albania and Estonia are in the early stages of development. That pattern is likely to be repeated across the region.

Secondly, since the end of communism, all five countries have been engaged on a programme of reform in order to bring their respective systems into line with a model of administrative procedures which has come to be accepted across both eastern and western Europe. It may be premature to talk of a European conception of administrative law, but the high level of consensus that emerges from a comparative study of national systems suggests that the idea is far from fanciful. This consensus is reflected in the common approach to the procedures which ought to govern the making of administrative acts and decisions, and to the principles which ought to mediate the relationship between the administrative body and the parties affected by its actions. Allowing for local variations and for different stages of progress, the consensus on fundamentals is indeed firm.

A third general point emerging from the following study of administrative procedures is that a certain tension exists between the procedural regimes of the communist period and those which are more suitable to a democratic, rule of law system. The tension is especially apparent in the three countries - Bulgaria, Hungary, and Poland - which adopted administrative procedure codes during the communist period and then simply modified them to make them more suitable for a democratic, rule of law system. This piecemeal approach offers a sense of continuity and incremental adjustment, but it may be that the assumptions of the two very different periods are themselves so different that a complete redrafting of the codes of procedure should be considered.

\section{Supervision of the Administration}

The second part of the report deals with the supervision of the administration. Judicial supervision by the courts occupies a substantial part of the analysis, but the idea is to give as full a coverage as possible of the kind of supervision provided by other bodies, including ombudsmen, inspectorates and special commissions, the Prosecutor, and parliamentary committees. As in the case of procedures, the stages of development of the five countries varies greatly, but again there appears to be less agreement as to the methods and institutions necessary to offer adequate supervision of the administration. 
While judicial supervision by independent courts is a central plank in the reforms of all five countries, this is confined to matters of legality. The most suitable forms of supervision of the content and merits of administrative actions are more debatable and divergent views are expressed. The ombudsman device has been adopted in Hungary and Poland, and seems to be working well; it has not, however, won support in some of the other countries. Considerable weight is placed in each of the countries on the role of inspectorates and special commissions, of which the Supreme Audit Institution is one of the most important, as forms of supervision, although a detailed study of the many forms such bodies take is beyond the scope of this study. Similarly, each country has created an extensive network of parliamentary committees, although in most cases the committees are only beginning to function as effective forms of scrutiny of the administration. Finally, while most countries have retained the office of prosecutor with some public law functions, it is not clear precisely what its role should be, especially in the light of the increasing invocation by citizens of judicial supervision.

\section{Behind the Studies}

Moving now from the substance of the studies, several comments should be made about the background and context to them. First, the reasons for choosing these five countries are set out in detail in the report, but it is perhaps worth noting here that they may be taken as representatives of different geographical, cultural, and historical groupings. They are also countries in which the author was already conducting research into administrative law and institutions.

Secondly, it may be asked what practical purpose the studies will have. Such questions are always difficult to answer, but it is hoped that the review of each country will be of interest to officials, legislators, and law reformers in that country. It is also hoped that the comparative element will be of special interest since it is not always easy for one country in the region to know what its neighbours are doing. And finally, the report should be of interest to readers in other democracies since it provides basic information about the countries of Central and Eastern Europe which is not otherwise readily available.

Another general point to make clear at the very beginning is that the studies here are meant partly to describe what is happening in each of the countries, and partly to offer constructive criticism of issues which need further consideration and possible action. In the author's opinion, the study of administrative law and administrative institutions in the region is endlessly fascinating and the developments there are most interesting. To the extent that a critical analysis is offered in this report, it is intended to be helpful and constructive, and should be read against a background of quite impressive achievement in most of the countries of the region in a few short years. It should be kept in mind that a similar study of western European countries would reveal very similar strengths and weaknesses in both their administrative procedures and their forms of administrative supervision. 


\section{PART I: ADMINISTRATIVE PROCEDURES AND THE SUPERVISION OF THE ADMINISTRATION IN HUNGARY, POLAND, BULGARIA, ESTONIA AND ALBANIA}

\section{Introduction}

\subsection{The Objectives of Administrative Law and Procedure}

Amongst the various purposes of administrative law and administrative procedures, two stand out as especially important. One purpose is to assist administrative institutions in carrying out the tasks set by government. The other is to ensure that people who are affected by the actions and decisions of administrative institutions should be treated properly and fairly. The first purpose may be called effective administration, the second respect for the rights and interests of persons.

\subsubsection{Effective Administration}

Effective administration means that each department, agency, local authority, or other public body exercises its powers in accordance with the purposes and standards defined by law in an economical and efficient way. The law specifies the powers conferred on each authority and sets the parameters within which they should be used. This image of administrative government is of course not the only one that might be envisaged, but it is the only one compatible with a commitment to the rule of law. For the rule of law maintains as a matter of principle that, with rare exceptions, all administrative authority should be grounded in and defined by law.

Within the legal framework, administrative authorities may have considerable discretion as to how their tasks are performed, but provided that discretion is exercised subject to certain constraints, it is not in itself incompatible with the rule of law. Administrative law and procedure not only sets the parameters within which public authorities should act, but also contributes to the quality of decision-making. Standards requiring openness, hearings, the gathering of evidence, the giving of reasons, and providing for recourse can be seen as ways of improving the quality of the outcomes and, therefore, the effectiveness of administrative government.

\subsubsection{Respect for Rights and Interests of Persons}

Administrative government, however, is concerned not only with effectiveness but also with the manner in which people are treated. Administrative authorities, whether they are ministers, departments of state, local government, or special statutory bodies, exercise great powers over citizens. Many of the basic goods in society, such as welfare benefits, housing, school places, and subsidies are distributed through the administration. Many activities, ranging from the practice of a profession, through the carrying on of various kinds of business undertakings, to the building of a house, may be conducted only with the grant of a license or permission by an administrative body. These are just a few examples of the innumerable ways in which the life of a society and the activities of the citizens within it are regulated and controlled by administrative government.

Some societies are more regulated and controlled than others, and it may be that the curbing of the degree of state regulation is a desirable goal to be aimed at in modern democratic societies. However, while the 
precise level may be a matter of debate, a relatively high degree of administrative government regulation is an indispensable feature of a peaceful, stable, and well-governed society. Administrative government, and the regulation of the life of the citizens that unavoidably accompanies it, is not only a necessary but a desirable characteristic of a good society.

However necessary and desirable administrative powers may be in the interests of good government, they do raise important issues about how people should be treated. For whenever questions arise as to the distribution of benefits or the imposition of burdens on persons, then considerations of rights and fair treatment are also in issue. In a society based on the rule of law, it is important that such powers (which will be referred to under the general title "administrative powers") should derive from the legal authority of the constitution or parliamentary enactment, and that they should be stated with reasonable certainty and clarity. But while proper legal authority is a necessary condition for the exercise of administrative powers, it is not sufficient. It is not sufficient, in other words, to show that administrative powers are derived from a legitimate legal source, because other principles are needed to ensure that, in the use of those powers, persons are properly and fairly treated in the administrative process.

\subsubsection{Principles Shaping Administration}

Those additional principles are provided by administrative law and procedure and should include such matters as openness in the conduct of administration, participation in the process by those whose rights and interests are at stake, impartiality on the part of the administrators, the specification of the criteria of decision-making, a reasoned decision, and the disclosure of the reasons. Where there is discretion under the law, it ought to be structured through guidelines which give a reasonable indication of how the discretion will be used; it should also be used in good faith for the right purposes, taking account of relevant factors, in a manner which is reasonable. There should be provision for interested parties having access to legal or other specialist advice, and for being able to seek recourse against an unfavourable decision before an independent court or tribunal.

Some of these principles can be derived from the principle of legality itself. The very idea that an authority has no power to act other than in contexts and ways authorised by law derives from the principle of legality. That the legal standards governing an exercise of authority should be applied accurately and properly, and that procedures and institutions need to be created for that purpose, again can be derived from legality. The principle of legality extends beyond the immediate and direct laws governing an area of administrative activity. The principle may be taken to include the constitution of the country which will often contain principles guiding and constraining the administrative process.

Examples are that persons should be treated with equal concern and respect, and not be discriminated against; that certain information should be made available to them; and that decisions should be made in accordance with due process and procedural fairness. In addition to the constitution, there may be general laws which state general principles to apply to administration. Laws relating to freedom of information and the protection of privacy are one kind, codes of administrative procedure another. And finally, the superior courts may themselves be an important source of general legal principles relevant to administration. The French Conseil d'Etat and the British superior courts have both been of great general importance in creating and extending general principles of law which guide and constrain administrative proceedings. 


\subsubsection{Rights in Relation to Administration}

The principles which derive from these various sources may in turn be linked to rights. The first source of rights is the constitution of the country. These are usually rights that guarantee that certain important values be respected in all areas of law and administration. Examples of such rights are that persons be equal before the law, that they not be discriminated against, that certain information be made available to them, and that decisions be made in accordance with notions of due process and procedural fairness. The second source of rights is the law laid down by the legislature or other law-making authority. These may cover a myriad of matters ranging from welfare benefits, across the grant of licenses to conduct various activities, to a child's right to have a place in school. To the extent that the substantive laws of these kinds are for the benefit of individual persons, then they have rights to that benefit. It follows also that the citizen has a right to such laws being applied properly and accurately to the case in hand.

There is nothing mysterious about legal rights, for to have a right is just to have a claim to a certain state of affairs where that claim is created under and protected by law. If the statute states that a person shall be granted a license to conduct some activity, perhaps to establish a business or to practice a profession, upon meeting certain criteria, then the person who does meet the criteria has a right to the license. The person need not appeal to the goodwill or decency of the official or authority, but instead asks that society's own commitments to each of its members, commitments expressed in its laws, be honoured. In each case, the person whose interests are in issue has a right that the law laid down by the society should be applied accurately and properly in each case.

Thirdly, the courts themselves in exercising their powers of judicial review of administration may create principles governing the administration which in turn are the basis of rights. The role of the courts in western jurisdictions in this area was noted above; the same judicial initiative can be seen in some of the countries of Central and Eastern Europe. Fourthly and finally, rights relevant to administration may derive from international treaties, the most notable of which in the European context is the European Convention on Human Rights.

We should notice that rights do not simply happen or occur; they depend for their recognition and application on suitable institutions. At the higher levels, the courts have the final say; in day to day affairs, however, rights are dependent on the education, training, and attitudes of officials.

\subsubsection{Legality}

The principle of legality is the foundation stone of administrative law. Much of what has been said in this section is related to the principle of legality, but a brief restatement of its main elements may be useful. The principle means at its simplest that: (i) all administrative and executive authorities are created by law and have only such powers and duties as are conferred on them by law; and (ii) in exercising their powers and duties such authorities should act within the law, and any act or decision which goes beyond the scope of legal authority or violates the law in a significant way should have no legal effect. While these two elements are often thought to be enough, I suggest that in order to be complete, a third should be added: (iii) the legality of any administrative action should be open to review by an independent court at the suit of a person or group of persons who have an interest in the matter or, in some cases, at the suit of a public official, such as the prosecutor, who has the authority under law to act in the public interest. 
In determining which laws give content to the principle of legality, various sources must be considered. Such sources may broadly be grouped as follows:

i. The Constitution may contain important principles which limit and constrain the powers of an administrative authority. Such principles may be particular to the authority (limitations on the powers of the President or a minister, for instance), or they may be general as in the case of a principle of equal treatment and protection or a principle of due process.

ii. The substantive law, as enacted by parliament or the national assembly (and possibly with the consent of the President), which confers powers and duties on the administrative authority. Such laws or statutes constitute the substance of legality and define the nature, content, and scope of the legal authority of administrative institutions.

iii. General codes of administrative procedure are a third source of legal rules and principles as the following pages in this report demonstrate. Such codes are typically a mixture of detailed procedural rules on the one hand and general procedural principles on the other hand. To illustrate, the same code may combine precise rules about the time limits for challenging an administrative action with a statement of the general principle that interested parties should have the opportunity to participate at all stages.

iv. Fourthly, the courts exercising review of administrative actions may devise general principles which ought to be respected by administrative authorities. Indeed, as noted in this report, in a number of eastern and western European jurisdictions, the courts have been the source of numerous principles and generally a creative influence in the development of administrative law.

v. Finally, just as international treaties may be the source of rights, so they may contain principles which give meaning and content to the principle of legality. In the European context, the European Convention on Human Rights is especially important as most of the countries of Central and Eastern Europe become members. Amongst various provisions of the Convention which are relevant to administrative procedures, Article 6 (1) is noteworthy in its statement of the principle of procedural due process.

\subsection{Administrative Law and Procedure in Central and Eastern Europe}

\subsubsection{The Choice of Countries}

This is a study of administrative law and procedure in selected countries of Central and Eastern Europe. The countries studied are: Hungary, Poland, Bulgaria, Estonia and Albania. Each country has a different cultural and historical background which is reflected in its legal system. The one common factor is that all five were communist states until relatively recently and each was influenced to a varying but considerable degree by the dominance of the Soviet Union. Within the group, the development of administrative law varies greatly. Both Poland and Hungary have administrative law codes dating from the 1950's and 1960's which, although substantially amended in recent years, retain much of their original approach and structure. A detailed analysis is given in the following report, but it may be worth observing here that both countries have advanced systems of administrative law, comparable to the countries of western Europe. At the same time, each bears the hallmarks of a certain approach to law and administration characteristic of the communist period.

Bulgaria's administrative procedure code, first enacted in 1970, also derives from the communist period, although important amendments have been made in the post-communist years. Neither Estonia nor 
Albania have administrative law codes and, indeed, it is true to say that their systems of administrative law are seriously under-developed. However, efforts are being made in both countries to create modern administrative institutions and to update their administrative law, but progress appears to be slow.

These five countries were chosen for this study for a number of reasons. In the first place, each represents a different historical tradition and geographical setting, ranging across the Baltic states, the former Austro-Hungarian empire, the Balkans, and, in the case of Albania, the Mediterranean end of eastern Europe. A second factor in making the choice was the different states of development of the various countries. As noted above, the disparity between Hungary and Poland at one end and Albania at the other end, with Bulgaria and Estonia broadly in the middle, is very considerable. A third factor which carried some weight in the choice of countries was that the author of this report was already engaged in research into administrative law in four of the five countries. This research overlapped to some degree with the present study and provided some useful material for it.

\subsubsection{Administrative Law during the Communist Period}

It may be helpful to comment briefly on the sense in which administrative law during the communist period had a distinctive character ${ }^{1}$.

The elements of that distinctiveness are several. First, public administration was under the control of the executive and the party, and was regarded as an instrument for achieving the objectives. The test of good administration was how successful it was in achieving the objectives. Systems of scrutiny and accountability, to the extent that they existed, were largely internal to the administration. Such systems were directed primarily at satisfying the requirements of the party and the executive then at meeting standards set by external bodies.

Secondly, while the creation of forms and institutions of scrutiny external to the administration has been a prominent feature of the post-communist period, such external controls hardly existed during the communist period. The review of administrative action by independent courts, which is now considered an essential requirement of a sound system of administrative law, was unknown in many countries and rarely exercised in others. Other external forms of control, such as ombudsmen, parliamentary committees, inspectorates, and special bodies of other kinds, were largely non-existent, at least until the last years before the collapse of communism.

A third feature of administrative law during the communist period was the tendency in many countries to adopt general codes of administrative procedure which applied to most administrative authorities and which usually stated in detail the procedures to be followed by them in taking individualised administrative decisions. While existence of administrative codes is not of course unique to former communist countries, the character of those codes is. For not only do they confirm the closed nature of administrative government, but they also demonstrate two more specific factors: first, that the citizen's relationship to the administration was not characterised in terms of rights; and secondly, that the means of recourse from a primary decision were to superior, internal administrative bodies rather than to independent external bodies such as the courts.

The final hallmark of administrative law during the communist period was the power of the prosecutor. The prosecutor was much more significant than the courts and typically had extensive powers to ensure

1 This idea is developed in more detail in D.J. Galligan, C. Nicondrou, and R. Langan (eds.), Administrative Justice in Central and Eastern Europe (1997). 
that administrative bodies, non-governmental organisations, and private citizens all complied with the legality. The prosecutor could initiate action against an administrative body of its own volition or it could respond to complaints from citizens. The precise powers of the prosecutor varied from country to country but, most countries of the region followed the Stalinist model according to which the prosecutor, who was directly responsible to the party, wielded very wide powers over all parts of society.

\subsubsection{An Approach to Administrative Law in the Region}

Before looking more closely at each of the countries, it is important to sketch an approach which will guide our understanding of the issues for the central and eastern European countries and perhaps be of practical use to those in each country charged with reforming the system. I suggest an approach at two levels. At the first level, the task is to identify the most important features of an administrative law system. This in turn means specifying the values and standards which ought to be at the foundation of administrative government in a modern, democratic, and liberal society, and then seeing what institutions, doctrines, and procedures are necessary to translate those values and standards into practical law. This activity is essentially concerned with the construction of a legal framework which is sound in principle and workable in practice.

In order even to describe, let alone offer constructive criticism of the existing systems in central and eastern European countries, we need to have in mind a model of administrative law. Now it may be objected that any such model is bound to be just one amongst several possibilities, so that the choice of one rather than another is arbitrary. While there is some truth in this claim, I wish to suggest that a fairly clear model of administrative law is emerging in the law of western European countries and in some of the central and eastern European countries. The model is being developed with energy and imagination by the European Court of Justice and informs the work of the Council of Europe and the European Court and Commission of Human Rights ${ }^{2}$.

While the emphasis here is on the distinctively European perspective, it should be noted that a similar model underlies the administrative law of the United States and has driven contemporary reforms in Australia, Canada, New Zealand, and other countries of the British Commonwealth. It may be premature to claim for such an approach to administrative law the generality and universality which seems unquestioned in relation to human rights, but the foundations have certainly been laid and the analogy with human rights is not entirely fanciful. It is not my purpose in this report to analyse in any detail this emerging model of administrative law, but many of its features will be identified in the following discussion of the five countries.

While the creation of a sound framework of law and legal institutions in the emerging democracies is essential, that in itself is not enough. It is equally important that improving the quality of administrative decision-making at first instance should be a primary objective. There is a temptation, to which lawyers in particular are prone to succumb, to assume that it is enough in securing administrative justice to pass a suitable administrative law code and then to provide for various methods of appeal and review to independent courts. Without detracting from the importance of this, the reality is that the vast majority of administrative actions do not go beyond the first instance ${ }^{3}$. We know from empirical studies that forms of appeal and review, even where such forms are informal and easy of access, are of very limited efficacy in

2 The idea of a European, if not universal approach, to administrative law can be seen in the manual of administrative law being prepared for publication by the Council of Europe.

3 For further discussion of this, see: D.J. Galligan, Due Process and Fair Procedures (Clarendon, Oxford, 1996); J.Baldwin, N.Wikeley, and R.Young, Judging Social Security (Clarendon, Oxford, 1994). 
remedying mistakes or abuses at first instance ${ }^{4}$. For most people affected by administrative action, the first act or decision is the final one; it then becomes vital to both good government and administrative justice that such acts and decisions should be of good quality.

How to improve the quality of administrative processes is a complex matter to which there is no straightforward solution. The most important factors are likely to be the level of education and training of the officials themselves, the provision of adequate resources to allow decisions to be made carefully after due consideration of the evidence, the creation of various forms of supervision and scrutiny, and, perhaps most important of all, the general cultivation of an ethos which permeates the administrative process at all levels. Administrative law cannot itself provide each of these conditions, but it may be able to help in a moderate way. Clear standards guiding the decision process, a commitment to openness in administration, a concern to hear the case put forward by interested parties, to disclose to the parties evidence and documents relevant to the issue, the giving of reasons, mechanisms for internal as well as external scrutiny, easy access to forms of appeal and review are some of the ways in which an administrative procedure code can contribute to good quality decisions on the part of administrative authorities.

To sum up, the claim being made here is that administrative law reform should proceed at two distinct but related levels. The object at one level is to create a framework of legal standards and then to establish the courts and other institutions necessary to give effect to those standards. The creation of such a framework is a necessary feature of a modern, democratic society where it is recognised that government should be conducted according to law and with respect for the rights of individuals and groups. The foundation here is a sense of normative political and legal theory which is coming to be regarded by civilised nations as general and universal. The object at the second level is entirely compatible with the first, but it goes further and looks to the social reality of administrative organisations. It draws on empirical facts about how such organisations work in daily practice and then tries to mould the law and legal institutions around those facts.

In conditions of scarce resources where officials are often poorly trained and where an acceptable ethos of administrative government is in its early stages, the capacity for improving public administration is severely limited. Nevertheless, if we lower our sights and concentrate on the slow process of building an administrative culture, then administrative law and procedure can make a modest but real contribution. This approach to administrative law reform is of course rather idealistic; in practice, especially in countries which are still developing their most basic institutions and practices, the nature and pace of reform will be shaped by influences of various kinds, from those of high principle to others of pure expediency.

\subsection{The Object and Scope of this Report}

The main object of this report is to describe the present state of administrative procedure in the five central and eastern European countries noted above. In doing so, I shall be guided by the specific objects to:

- $\quad$ identify and describe the laws governing administrative processes;

- $\quad$ give a brief account of the background to those laws;

- $\quad$ indicate current proposals for change or innovation with respect to them; and 
- make a comparative analysis across the five countries of the most significant features of administrative procedures.

While it is important to create a sound legal structure in the emerging democracies of Europe, it is also important to understand the workings of the law in practice. That I shall attempt to do in this report to the extent that information is available. The gap is always wide between legal codes as they appear in the books and what happens in daily practice in the agencies and departments of government. Since law is meant to be a practical guide to action, it is important that it should be applied in the way it is intended. That can never be achieved perfectly but it can be achieved at all only if an effort is made to understand what happens in the social reality of different administrative bodies. This is not to say that law and social reality are two different and incompatible concepts; on the contrary, law is part of social reality and exerts great influence on the way officials and parties understand their social environment. The great challenge in reforming the law or in developing new legal approaches is to understand the social context, so that the law can be both responsive to it and capable of exerting greater influence over it.

Now of course to understand fully how administrative law and procedure works would require major empirical studies which do not exist either in western or eastern European countries. In recent years, however, the interest of researchers in these matters has grown and empirical studies of particular issues are being conducted. I shall draw on those studies wherever possible in compiling this report. I shall also draw on a study presently being conducted under my direction jointly by the Centre for Socio-Legal Studies of the University of Oxford and the Centre for Constitutional and Legislative Policy (COLPI) in Budapest. The study is entitled Administrative Justice in Central and Eastern Europe (referred to as the Administrative Justice Project) $)^{5}$.

The study aims to learn how administrative laws, procedures, and institutions work in selected countries of Central and Eastern Europe. This is done by conducting six case studies in each country of different administrative processes, the idea being that each will demonstrate interesting and significant features of administrative law and practice. The countries being studied are Bulgaria, Estonia, Hungary, Poland and Ukraine. Since the first four countries are the subject of this report, some aspects of the Administrative Justice Project will be drawn on in gaining an inkling of how administrative law works in practice.

In preparing this report, the primary materials on which I have relied are the laws and regulations of each of the countries. The laws and regulations of the five countries relevant to the issue of administrative procedures, with few exceptions, have been collected and translated into English through the good offices of the SIGMA Secretariat in Paris. Apart from the interest of the report itself the collection and translation of these laws is a valuable by-product of this project.

While an analysis of the relevant laws and regulations is the basis of this report, use has also been made of secondary materials, in the form of articles or reports, which have dealt with issues of procedure. The analysis of the laws and regulations was followed by a series of extensive interviews which I conducted in each of the five countries. Those interviewed usually included senior officials from the Ministry of Justice and other ministries with an interest. Interviews were conducted also with judges from various courts, although I concentrated on those involved in administrative cases. The issues here were also discussed with lawyers, university teachers and scholars, and assorted other parties. Interviews were sometimes conducted in English, sometimes in the interviewees native language through an interpreter. Although time was limited and only a small selection of interested persons in each country could be interviewed,

5 The study will be published in 1997 as follows: D.J. Galligan, C. Nicondrou and R. Langan (eds.), Administrative Justice in Central and Eastern Europe. 
those with whom I did discuss these matters were very generous with their time and enormously valuable in helping me to understand better the issues of administrative procedures for each country.

\subsection{Procedures for Law-Making}

The administrative procedures included in this study apply, in general, to administrative actions of a particular and individualised nature; they do not apply to the law-making process, in the sense that law is made by administrative and executive bodies. The basis for this distinction and the exclusion of the latter is a matter of importance upon which a short word of explanation should be offered.

It should first be made clear, however, that the law-making function of parliament or the legislative assembly is not included in administrative procedures. Parliamentary procedures are usually stated in detail in standing orders or special rules of parliament, which normally cover the law-making process. We are not concerned here with those procedures. What is of interest from the standpoint of administrative law is the secondary law-making process, which may itself take various forms.

First, it is usual for senior officials such as the president, the council of ministers, sometimes individual ministers and local government, to have constitutional authority to make laws by way of regulations, decrees, or orders. Secondly, law-making authority of a secondary nature may be conferred on a minister, department, or agency by a primary statute or law. The nature and scope of such power will be determined by the primary law. A third form of law-making is of a more informal kind; it occurs when an authority formulates guidelines and policies in the exercise of a discretionary power. Informal legislation of this kind is common in administration and raises interesting and important issues.

The general point to note for our present purposes is that the law-making process in these secondary senses falls outside the scope of the codes of administrative procedure in Central and Eastern Europe. There are occasional laws dealing with such procedural issues, but it must be said that inadequate attention has been paid in all the countries of the region to administrative law-making, or the making of normative acts to use the terminology familiar to continental jurisprudence. Just what procedures should govern law-making by administrative bodies is a matter of discussion; it is also a matter on which various western jurisdictions have well-developed procedures. The issue is not considered in any detail in this study, but it is a matter which raises important issues and which awaits serious consideration in the region.

\subsection{Substance and Procedure}

The study emphasis is on the procedures of administrative action; that is to say, it is concerned with the procedures to be followed by administrative authorities in doing acts and making decisions. Administrative procedures are to be distinguished from the substantive laws which apply in different contexts. The substantive laws state the powers and duties of an administrative authority and often impose a complex network of legal rules about how those powers and duties should be exercised.

The distinction between substantive and procedural laws is of great importance; it is not, however, always clear or precise. I shall not here venture into an analysis of the relationship between the two, except to note two general points. First, codes of administrative procedure express general rules which apply to a range of administrative authorities and types of administrative action. The rules they state are rather general and abstract, and need to be supplemented by more detailed procedures. The additional details are often expressed in the substantive law governing a particular matter. Accordingly, it is not unusual to find procedural issues dealt with in substantive laws. The code of procedure is often a starting point which is 
developed in detail in the substantive law. Secondly, in those areas of administrative action which are excluded from the codes of procedures (and we shall see that none of the codes are comprehensive in their coverage), procedures will often be laid down in the substantive law. It should be noted, however, that, in a significant range of matters, procedures are left almost entirely to the administrative authority itself.

\subsection{Third Parties and Interest Groups}

One feature of the administrative procedures examined here is that they tend to concentrate rather narrowly on those persons who are the direct subject of administrative action. Subject to some important exceptions, the codes do not deal with the position of third parties who may have an interest in an administrative action, without being directly subject to it. And yet, if we pause to consider the matter, it is often the case that third parties have a real interest and, therefore, an expectation that they should have the chance to be involved in the process in various ways. The issue becomes especially important with the growth of interest groups as part of the regeneration of civil society in the region. Again, I cannot explore this issue in any depth here, but it should be kept in mind that substantial reconsideration of administrative procedures may be needed if interest groups and third parties are to be adequately recognised.

\section{Hungary}

\subsection{The Legal Background}

Hungary has a long tradition of well-developed laws and legal institutions which reach far back into ideas and practices of the Austro-Hungarian empire. The enlightened and progressive characteristics of the later empire have influenced and shaped Hungarian ideas and institutions in significant and enduring ways. Administrative law was amongst the more advanced elements of the empire and Hungarians note with pride the advanced nature of administrative law and administrative institutions during the hundred years up to the Second World War. After the communist take-over in 1945, changes in official attitudes meant that administrative law was regarded as less important and many of its principles and procedures fell into disuse. In particular, external scrutiny of administration by the courts was considered unnecessary and the citizen's right to seek judicial review, which was reasonably settled before 1945, virtually lapsed after that time. Each area of administrative activity had its own procedures and, to the extent that supervision was needed, it was considered to be best exercised by the administration itself.

In 1957, a year after the uprising and five years after the passing of a Code of Civil Procedure, the enactment of the General Rules of State Administration Procedures ${ }^{6}$ marked a major reform of administrative law. Some of the ideas of pre-1945 were revived, but the adoption of a general code of procedures for administrative acts and decisions was a notable innovation. One object of the code of procedure (which I shall refer to as the General Rules) was to consolidate the many special procedures into one set of general procedures. The General Rules were not intended, however, to be comprehensive and several important areas of administrative action were excluded from its scope. A second object of the General Rules was to make the administration responsible for its own regulation and supervision, with recourse to external authorities being allowed only in exceptional cases. The preferred method of recourse was for persons aggrieved by the actions of an administrative body to seek recourse by appealing to a higher authority within the administration itself.

$6 \quad$ Act IV of 1957. 
The Hungarian Parliament has amended the General Rules of State Administration Procedures on numerous occasions. One of the effects of substantial amendments made in 1981 was to open the way for limited judicial review of administrative action, while further amendments followed in the post-communist period from 1990 onwards. As a result of major changes in 1991 to the Constitution and to the General Rules $^{7}$, judicial review of administration has been securely established and may well become the main form of supervision.

\subsection{Constitutional Factors}

The Hungarian Constitution, adopted in 1949, but amended in important ways in the post-communist period, contains several articles relevant to administrative law. First, it requires that there be harmony between the Hungarian legal system and obligations assumed by Hungary under international law ${ }^{8}$. One effect of this is to introduce into Hungarian law the principles of the European Convention on Human Rights, the procedural due process provisions of which are of special significance for administrative law.

Secondly, Article 57.5 of the Constitution confers on all persons within the State of Hungary a right to seek a remedy against an administrative authority which has infringed the person's rights or lawful interests. Related to this is the duty imposed on the courts under Article 50 to review the legality of decisions of the public administration. This clause is of great importance in giving a constitutional basis to the citizen's right to judicial scrutiny of administrative action and it paved the way for the amendments to the General Rules noted above.

Thirdly, the Constitution creates a Constitutional Court which has jurisdiction to determine whether laws or actions are constitutional ${ }^{9}$. Provision is also made for creating by law special Courts in specific areas of activity $^{10}$. This article is adequate authorisation for the creation of special administrative courts, but there are no plans at present to do so. Judicial review of administration is conducted by a special division of the ordinary civil courts.

\subsection{Overview of Administrative Procedures}

The General Rules of administrative procedure apply, in general, to individualised acts and decisions done or made by administrative bodies. The rules express in detail the procedures to be followed at first instance and, more sparingly, on appeal or review to a superior administrative authority. Provision is made for interested parties to be given notice of and to participate in the process. Provision is also made for the parties to have access to documents and other information relevant to the case, subject to certain restrictions in cases of national security. An administrative authority may normally proceed as it thinks best, collecting evidence and hearing witnesses until it is able to decide the facts and deal with the case properly on the merits. In some cases a more formal trial may be held, but that is relatively unusual. The General Rules deal with issues of impartiality, legal representation, the use of experts, and the giving of reasons.

Extensive provision is made for recourse from the decision at first instance. The emphasis in the General Rules is on appeal to a superior administrative authority, with the possibility of a further appeal to a court

$\begin{array}{ll}7 & \text { Act XXVI of } 1991 . \\ 8 & \text { Article } 7 . \\ 9 & \text { Article 32A.1. } \\ 10 & \text { Article 45.2. }\end{array}$


on matters of law. The procedures to be followed on appeal are not treated in any detail in the General Rules but are governed by the Civil Procedure Code. Following this overview, I shall now examine some of these matters in more detail.

\subsection{Scope of Administrative Acts}

The General Rules constitute a set of procedural standards to be followed by administrative authorities in exercising their powers. The first general point to note is that such standards should be regarded as a minimum which may be, and indeed often will be, supplemented by more detailed and possibly more exacting procedures in specific areas of administration. In order to form a complete picture, therefore, of administrative procedures it would be necessary to examine each area of administration. A second general point is that, while the General Rules apply generally to all kinds of administrative acts and decisions, there are certain limitations on their scope. The limitations are set-out below.

The scope of application of the General Rules is limited in several ways: (i) one form of limitation is based on the character of the act; (ii) a second limitation is that various matters may be excluded by law from the scope of the General Rules; and (iii) the third limitation concerns the nature of the administrative body itself.

\subsubsection{The Character of Administrative Acts}

As to the first of these, the General Rules apply to a public administration organisation "when conducting a state administration procedure"11. Although this rather awkward expression is neither defined nor elaborated in the General Rules, it may be taken to cover the broad range of acts and decisions of administrative bodies dealing with individualised cases. The only specific guidance given as to the scope of a public administration procedure is that certain kinds of acts are declared to be within it. These examples are, presumably, illustrations of the main instances of public administration procedures rather than an exclusive definition. The principal case is where a state organisation identifies a right or duty in respect of a party.

It may be that the word identifies is not a good translation of the Hungarian, but the key idea seems to be that, where a person's rights or duties are affected by an administrative procedure, the General Rules apply. The practical scope of the General Rules depends on the interpretation given to the condition that rights or duties be affected. On a strict construction, the General Rules would not apply to administrative actions in which interests rather than rights are at issue. This may be the case in many areas of administration, especially where a whole range of interests of different persons and groups are affected, as in the environmental field for example. The scope of the General Rules would be severely curtailed if it were interpreted in this narrow way. Indeed, one area in which the General Rules needs careful reconsideration concerns persons and groups (including interest groups) who have an interest in an issue but are not direct parties to it $^{12}$.

11 Section 1, subsection 1, section 3.

12 The English translation of the General Rules uses the term "client" to refer to those persons who are directly subject to an administrative action, and the term "party" to refer to a person whose interests may be affected in some way by it. A better approach, it is suggested, would be to use the generic form "party" to cover both categories. 
The other cases where the General Rules are stated expressly to apply are where the organisation certifies data, keeps records, or conducts an official review ${ }^{13}$. The last of these activities, the official review, refers to the powers which authorities have to investigate the affairs of a party where that is necessary for the authority to discharge its functions ${ }^{14}$.

\subsubsection{Administrative Acts of a Legislative Nature}

One important limitation on the scope of the General Rules is that they do not apply to the legislative activities of the government and administration. Within the Hungarian legal order, legislative powers are vested in a number of institutions and officials, including the President, the Cabinet, the Prime Minister and individual ministers, under-secretaries of government departments, and local government. In addition to such formal legislative powers, a whole range of authorities make informal rules in the exercise of their discretion $^{15}$. The procedures for making normative acts, as the legislative process is referred to in continental legal systems, are to be found, to the extent that they exist at all, in the specific parliamentary laws under which the delegation is made. It has not been possible in the course of this inquiry to examine the procedures for making normative acts. However, on the basis of information I have obtained from interviews with various officials, it appears that the position varies from one area of law to another and that in general procedures in relation to normative acts are relatively undeveloped.

The one attempt at a general law governing procedures in this context is the Act on Legislation ${ }^{16}$. This is an interesting and important piece of legislation which warrants closer analysis than I can provide here, but several provisions are worth passing reference. Section 19 states that citizens, either directly or through their representative organisations, are to participate in preparing and enacting the laws relevant to their living conditions. Administrative bodies, non-governmental organisations, and interest groups are to be involved in drafting any such laws ${ }^{17}$. The drafts of ministerial decrees should be circulated to non-governmental organisations and interest groups before the text is finalised ${ }^{18}$. Just what effect these and other provisions have in practice is an important matter awaiting further study.

\subsubsection{Acts Excluded under the General Rules}

Returning now to the scope of individualised actions, it is to be noted that procedures involving petty offences and issues of citizenship are expressly excluded from the General Rules ${ }^{19}$. There is a special law dealing with administrative penalties dating from 1968 which is currently under review ${ }^{20}$. It is unclear, moreover, whether the General Rules apply to investigative processes carried out by administrative bodies, in certain areas, such as the investigation into the affairs of a company, bank, or insurance company. Such investigative processes often do not result in a definite decision, but, nevertheless, may raise important

\footnotetext{
13 Section 3.1.

$14 \quad$ Sections 54 to 57.

15 One set of case studies in the Administrative Justice Project examines the making of informal legislative rules by administrative authorities.

16 Act No. XI of 1987, as amended.

17 Section 20.

18 Section 29.

19 Section 3.7.

20 See Law on Administrative Penalties (Act 1 of 1968).
} 
questions of procedure ${ }^{21}$. The test under the General Rules appears to be whether the rights or duties of a natural or legal person are affected by the investigation.

\subsubsection{Acts Excluded by Law}

The second limitation on the scope of application of the General Rules applies where certain administrative actions may be excluded by express legal provision, that is to say, by a specific law of the Parliament. The areas $a^{22}$ : national defence, foreign trade, administration and social security, unfair market conduct, price setting, and tax and revenue cases. Some of these areas of possible exemption make good sense, but the case for excluding areas such as social security and tax and revenue, is not obvious and appears anomalous. It appears, however, that in practice it is rare for this avenue of exclusion to be invoked. All other areas of administration are subject to the General Rules unless provision for exclusion is made in the General Rules themselves ${ }^{23}$.

\subsubsection{Types of Authorities outside the General Rules}

The third type of limitation on the application of the General Rules is the nature of the administrative authority acting or deciding. The general principle is that the General Rules apply to "public administration organisations ${ }^{\prime 24}$. The term is not explained in the act, but may be taken to include the full range of administrative bodies from central departments to local government. The General Rules also specify that certain "entities" which are not part of public administration are subject to the General Rules if they are authorised under law to conduct a state administration procedure ${ }^{25}$. The idea is to broaden the net of bodies beyond the standard organs of government to cover other kinds of bodies exercising administrative functions.

\subsection{Background Principles}

Administrative procedures must be conducted in accordance with the Constitution. Article 7 states that Hungary's legal system shall acknowledge the rules of international law and shall ensure that domestic law is compatible with such rules. Fundamental human rights are declared to be recognised in Article 8 and a duty is imposed to establish such rights in Hungarian law. The obligation to respect human rights falls on administrative bodies as well as other parts of government. The Constitution grants any person the right to seek judicial redress against a decision of the government or administration which breaches fundamental rights ${ }^{26}$.

21 For an analysis of the procedural issues in this context, see D.J. Galligan, Due Process and Fair Procedures. Investigative processes were also one of the matters examined in the Administrative Justice Project.

22 Section 1, subsection 1; and Section 3, subsection 6.

23 Section 1 , subsection 8 .

24 Section 1.

25 Section 1, subsection 2.

26 Article 70K. 
The General Rules begin with a statement of basic principles governing the conduct of government and administration. Some of the principles stated are of a very general nature:

- the duty of administrative bodies to enforce lawfulness, democracy, and humanism in their procedures $^{27}$;

- the duty of such bodies to facilitate the enforcement of rights, the performance of duties, and the strengthening of civic discipline ${ }^{28}$;

- a commitment to the active involvement of the population ${ }^{29}$;

- co-operation between the authorities, the parties, and other organisations or persons participating in a procedure ${ }^{30}$; and

- a commitment to speedy and simple procedures ${ }^{31}$;

Other principles are of more direct practical significance:

- all persons involved in an administrative procedure are guaranteed equality before the law ${ }^{32}$;

- all such persons are also given guarantees against discrimination or bias ${ }^{33}$;

- the parties to an administrative procedure have the right to be informed of their rights and obligations and to be heard ${ }^{34}$; and

- the parties to such a procedure have a right to recourse from the initial decision ${ }^{35}$.

Some principles within this second group are given more detailed consideration in later clauses of the General Rules; others, especially those in the first category, are more in the nature of aspirations and ideals for good administration rather than justiciable legal principles.

\subsection{The Course of an Administrative Action}

An administrative body has a duty to deal with any matter which falls within its jurisdiction ${ }^{36}$. If the administrative body fails to discharge that duty, action may be taken by a supervisory body requiring that it do $\mathrm{so}^{37}$. 
The first task for an administrative body seeking to discharge its obligations under a particular law is to satisfy itself that it has the legal authority or competence to deal with the matter at issue. Extensive provision is made in the General Rules for deciding the scope of authority of any agency and for resolving disputes about such matters ${ }^{38}$. These provisions are highly detailed and complex and rather difficult to follow; it should be possible to deal with such issues in a clearer and simpler manner.

An administrative action may be initiated either ex officio by the administrative body or by a party ${ }^{39}$. In the latter case, the application may be in oral or written form ${ }^{40}$. The forms to be used in initiating an action may be stipulated by law ${ }^{41}$. The law may also specify that the party be notified about initiating or continuing a procedure. The general rule is that a ruling should be made within 30 days of the receipt of the application or the ex officio initiation of the procedure ${ }^{42}$.

The administrative body may summon persons to appear before it to give evidence and it should set a date and place for the hearing ${ }^{43}$. Where the process has been initiated ex officio by the administrative body, the power to summon witnesses extends to summoning the party to give evidence; where, however, the process is begun by the party, the party may be invited to give evidence rather than summoned ${ }^{44}$. Experts also may be summoned to give evidence where there is provision in the particular law for doing so ${ }^{45}$.

An assessment should be made by the administrative body, in advance of any hearing, as to the facts that need to be established in order to determine the matter. In the light of that assessment, the administrative body may decide to gather its own evidence where it considers that to be necessary or where it is requested to do so by a party ${ }^{46}$. The administrative body also has power to conduct a survey with respect to any object or materials where that is necessary in making an assessment of the facts relevant to the case ${ }^{47}$.

The hearing of witnesses and experts may be conducted by the administrative body from time to time on a piecemeal basis during the course of the procedure. Alternatively, a trial may be held at which the witnesses will be heard and evidence presented. This may occur either where the law prescribes a trial or where the officials consider that the facts of the case make it necessary ${ }^{48}$. However, as noted earlier, trials are rarely held.

\subsection{Openness and Transparency}

The openness and transparency of administrative processes may be regarded as one of the most important objectives to be achieved in modern administrative law. The virtue of openness (which term I shall use as a general term which includes transparency) is that processes, which are in the nature of things likely to be

\footnotetext{
38 Chapter II. These issues of competence will not be discussed here.

39 Chapter III, subsection 1.

$40 \quad$ Chapter III, subsection 1 , section 16.

41 Section 16 , subsection 1.

42 Chapter III, subsection 1, section 15.

43 Section 22.

44 Section 27.

45 Section 32.

46 Section 26.

47 Section 31.

$48 \quad$ Section 36.
} 
secretive, become subject to outside scrutiny. That in turn has several advantages. It means that the parties involved in a process are able to know what is happening, are able to examine the law, facts, and evidence being relied on, and are able to participate in an informed way. Openness also means that scrutiny and supervision by other authorities of the primary decision-maker is facilitated and made more effective. And, finally, the need to work under conditions of openness, knowing that their actions are open to scrutiny, may influence the primary authorities towards better quality decisions. Openness can be achieved through various mechanisms some of which will be examined in the following sections in assessing the Hungarian situation.

\subsubsection{Freedom of Information Laws}

One mechanism in achieving openness is to impose on an authority the duty to make certain kinds of information available either as a matter of course or on the request of an interested party. Such information would normally include making known the criteria according to which decisions will be made. Laws of a more formal kind, whether statutory enactment, decrees, or regulations, will normally, but not always, be published and reasonably available. Laws of an informal kind, such as guidelines, policy statements, circulars, etc., are often made in the exercise of discretion where there are no procedures governing their making and no duty to publicise them. Openness requires that all such criteria should be stated and published ${ }^{49}$. Duties to publish such information do not exist under Hungarian law.

In addition, information should be disclosed concerning certain matters of public interest about the agency or department or which the agency or department has collected - reports, policy documents, background and discussion papers, etc. The information available would also normally extend to personal details or records held by the agency or department about individual persons. Information of this kind would normally be disclosed only to the particular person and would cover such matters as medical records, social security details, criminal records, etc.

These are the kinds of matters often dealt with in western countries in Freedom of Information legislation. The Hungarian law On the Protection of Personal Data and the Disclosure of Data of Public Interest ${ }^{50}$ covers some of the ground. The main elements of the Act are, first, to allow individuals to have certain controls over personal data held or collected by others, and, secondly, to allow citizens access to certain data of public interest. It is the latter that is of interest here. Data of public interest means any information in the possession of authorities performing the functions of the state or of local government or other public functions specified by law ${ }^{51}$. Such data does not include personal information.

Public authorities in Hungary are under a duty to promote the prompt disclosure of accurate information. The precise meaning of this duty is rather obscure, while more specific duties are imposed on authorities to publish or enable access of anyone to information relating to the activities of a public authority. This is a general provision, but express reference is then made to data relating to its activities, competence, organisational structure, the categories of data held by it, and the legal rules governing its operation ${ }^{52}$.

49 One technique for meeting the demands of openness is reflected in the Australian approach of requiring that an administrative authority may act on such informal criteria only if they are published: Freedom of Information Act (Cth of Australia) 1982, Section 3.

Act LXIII of 1992 as amended.

51 Section 2.3 .

52 Section 19. 
Exceptions are made for State and Official Secrets. Specific laws may also restrict access to information on various other grounds, including national defence, state secrets, criminal investigation, and international relations. Another law was passed in 1995 - On State Secrets and Official Secrets - which deals with the concept of State or Official Secrets. It covers such further matters as who may make the classification, what kinds of data can be so classified, and the procedure for doing so. I am not able to analyse these provisions here, but some misgivings were expressed in interviews as to how these laws were working in practice.

\subsubsection{Openness in Administrative Processes}

Another set of mechanisms aimed at openness relates to specific administrative processes. The guiding principle is that administrative decisions should be made in conditions of openness: that principle is then achieved through disclosing to the parties any information which is relevant to the process, allowing the parties to participate, giving an explanation and justification for the decision, and wherever possible conducting the proceedings in public. As the following analysis shows, these matters are dealt with in some detail in the Hungarian General Rules.

\subsection{Participation: Notice, Disclosure, and Hearing}

The important issues of participation generally, and of notice, disclosure, and hearing more specifically, are dealt with, first, as general principles and then, secondly, in more detailed provisions.

\subsubsection{Participation and Involvement}

There is a general duty on administrative bodies to involve parties in administrative processes. The General Rules state: administrative bodies "perform their duties with the population's active involvement. State administration procedures are built upon effective co-operation between the authorities, the clients and other organisations and persons participating in a process" ${ }^{\prime 53}$.

This may be seen as a general principle of participation and involvement which is given more precise meaning and content in several later sections of the General Rules, as set out below. The general principle might itself be the basis upon which the courts could develop more specific rules of participation, but it is not clear whether, in this context, the Hungarian courts will adopt an activist role.

\subsubsection{Notice}

General provision is made in the General Rules for the giving of notice, although the duty to do so is subject to an important qualification ${ }^{54}$. Notice must be given where the process is initiated by the authority, but obviously is not required when it is the party itself who begins the process. The qualification is that the general duty to give notice applies only when it is required under the specific law governing the matter. It was not possible in the present study to review the full range of laws to determine whether notice provisions are generally included; but it is clear from my interviews with officials that such provisions are not included as a matter of course. Practice varies with the result that in numerous

$54 \quad$ Sections 13.2 and 25. 
areas of administrative action, the notice provision does not apply. Where the proposed action affects a large number of parties, notice must be given by way of a public announcement.

Once an administrative process is underway, a party affected should be informed of the hearing of a witness or an expert, the conduct of a survey, or the holding of a trial ${ }^{55}$. The notice should indicate that the party is entitled, but not required, to be present and to participate.

\title{
2.8.3. Disclosure
}

The disclosure by the administrative authority to the parties of any facts or materials which will be relevant to its decision is an important element of openness. The general principle should be that, subject to exceptional matters such as state secrets, all relevant information held by the authority ought to be disclosed. The disclosure requirements in the General Rules do not amount to a clear principle of this kind. To the extent that any general provision is made, disclosure depends on the general principle of co-operation and participation ${ }^{56}$, together with the duty on the administration to inform parties of their rights and duties ${ }^{57}$. These two very abstract principles may go some way towards creating a general duty of disclosure of relevant law, facts, and evidence; they fall short, however, and are not a satisfactory basis for disclosure. A strong case exists for a clear duty of general application to be added.

A more specific duty is imposed in Section 26 of the General Rules which stipulates that the administrative authority shall clarify the facts necessary in formulating a ruling. That presumably implies that disclosure of those facts will be made to the parties. Such an interpretation is reinforced by Section 26.2 which places a duty on the official to provide the party with information before the latter exercises the right to be heard. This duty appears to extend to informing the party of the relevant law, but again it falls far short of a general duty of disclosure.

The administrative authority is under a duty to prepare a minute or record concerning the process, including the hearing of the parties, witnesses, and experts ${ }^{58}$. The minute should also include the essential statements and conclusions concerning the case ${ }^{59}$. The idea is that the minute or record should be made available to the parties, although this is not clear from the rules. Express provision is made for a party requesting and (presumably) being supplied with a progress report on the conduct of a trial or survey.

The only clear and direct statement of disclosure applies to documents ${ }^{60}$. A party or its representative has a right of access to any document created during the process, and may make copies. This right extends to other interested persons who are not themselves parties to the process. Although in a study of administrative processes relating to the control of water pollution it was found that the officials exercised substantial discretion in deciding whether to make the files readily available, especially to those who had an interest at stake but who were not parties ${ }^{61}$. The right of access does not extend, it appears, to other relevant documents which were not created for the process but are relied on by the administrative body.

\author{
$55 \quad$ Section 25. \\ 56 Section 2.4. \\ $57 \quad$ Section 2.6 \\ 58 Section 17.1. \\ 59 Section 17.2. \\ 60 Section 41. \\ 61 Administrative Justice Project: Study of the Control of the Discharge of Factory Effluent into Rivers.
}




\subsubsection{Hearing}

From the general right to be involved and to participate in an administrative process, it is not far to requiring that the party be heard. Express provision is also made for the right in Article 27 of the General Rules: subsection 2 makes reference to the right in general, while subsection 1 states that the right may be exercised by way of an oral or written statement. It is also made clear in the same clause that a party may refuse to make a statement.

Further reference to the right to be heard is contained in Article 36 of the General Rules which states that the administrative body shall conduct a trial into the matter where it is prescribed by law or where it is necessary for proper resolution of the matter that the various parties involved be heard at the same time. Where a trial is held, the parties, as well as witnesses and experts, shall be heard ${ }^{62}$. At any hearing, a party or its representative may comment on what has been said $^{63}$. A party may call witnesses and present evidence of its own ${ }^{64}$.

It is not easy to say exactly what form the hearing takes in different contexts or how well it works. In a study of the grant of licenses to establish private schools, it was found that the hearing was a vital element in the process, not only in providing an opportunity to the parties to make their case and to answer opposing cases, but also as a way of adding vital pieces of information to the original application. It is also an opportunity for the official to explain to the parties the matters at issue when, as is often the case, they are not clear. This is especially important in the absence of legal advice. Indeed, in this area of administration at least, the officials conducted the hearing more as an opportunity for informal consultation with the parties, than as a formal procedure ${ }^{65}$. It is then only a short step from consultation to elements of informal negotiation entering into the process. Informal negotiation was found to be a regular feature in the case studies conducted in the course of the Administrative Justice Project.

\subsection{Legal Representation}

While the General Rules do not deal expressly with legal representation, they do provide for "lawful representation or a proxy"66. This appears to include legal representation. Legal representation, however, is likely to be fairly rare for most parties involved in administrative processes. It should be noted, however, that it is now well established that legal or other specialist advice makes a big difference to how a party fares in any decision-making context ${ }^{67}$.

\subsection{Loss of Independence and Bias}

The general principle that an official or an administrative body should not be involved in its own case is stated in Section 19.1 of the General Rules. In western legal systems, this rather narrow idea has been used very creatively as the basis for various doctrines protecting against loss of independence on the part

62 Section 36.2 .

63 Section 36 , subsection 2.

64 ibid.

65 Administrative Justice Project: Case Study of Licensing of Private Schools.

66 Section 18.1.

67 See H. and Y. Genn, The Effectiveness of Representation Before Tribunals (Lord Chancellor's Department, London 1989). 
of an official ${ }^{68}$. Loss of independence may take several forms, but the most usual is bias or the suspicion of bias on the part of an official.

This idea is developed in the next section of the General Rules which prohibits a civil servant from involvement where he or she "cannot be expected to form an objective assessment of the case" ${ }^{169}$. Provision is also made for ensuring that an official involved at first instance should not participate in the same matter at a higher level. While the objective assessment principle is an acceptable way of expressing the requirement of independence and impartiality, it remains a rather abstract principle which ought to be spelt out in more detail. If part of the object of a code of administrative procedures is to educate and guide the actions of officials, then it is important that the guiding standards should be expressed with clearly and with as much particularity as is compatible with their remaining general standards. Again this is an area in which the Hungarian courts, in the exercise of judicial review, may create a fuller sense of bias and lack of independence, but there is much to be said for such details to be included in the code itself.

\subsection{Constraints on the Decision Process}

The general rules do not deal with a range of matters which in various western systems of administrative law are considered to be important constraints on the decision process, particularly when the administrative power in issue is of a discretionary kind. Such matters include the setting of informal guidelines and a ban on restraining discretion; the general principles against one official or authority abdicating, delegating, or surrendering its powers to another; the constraints on entering into contracts which restrict the authority's scope for acting as it thinks best at the time.

Principles such as these are often devised by the courts in the exercise of judicial review. The foundation of the principles is the concept of legality as interpreted by the courts and their main role is in constituting grounds upon which administrative action may be challenged in the courts. It is not always so clearly recognised, however, that grounds of review are also principles which ought to guide the exercise of administrative powers ${ }^{70}$. For that reason there is a good case for regarding such principles as properly included in a code of administrative procedure.

There is one matter arising in this context which warrants special mention: the issue of discretion and the avenues for controlling discretion. Two comments should be made. One concerns the impression, often given in central and eastern European legal systems, that discretion either is outside the law and illegitimate or, although within the law, is a kind of black box with respect to which law has no role to play. In western legal systems, however, efforts have been made, first, to recognise discretion as lawful and then, secondly, to break open the black box by understanding how discretion works and by devising legal techniques for its better regulation ${ }^{71}$. The principles referred to above are some of the techniques for achieving that end.

The second comment is that discretion occurs not only when expressly conferred, but often is implicit in the interpretation and application of standards and rules. A study of licensing of private schools in

68 For discussion of loss of independence, see D.J.Galligan, Due Process and Fair Procedures (Clarendon, Oxford, 1996).

$69 \quad$ Section 19.2.

70 An attempt to state the general principles as grounds of review can be seen in Australian legislation: Administrative Decisions (Judicial Review Act) (Commonwealth, 1977).

71 See K.C. Davis, Discretionary Justice (1969) and D.J. Galligan, Discretionary Powers (Clarendon, Oxford 1986). 
Hungary found that implicit discretion played a major part in the way decisions were made and that, in the absence of legal controls, its use varied greatly from one district to another. It was also noted in that study that heavy reliance was placed by officials on informal guidelines ${ }^{72}$. Much more could be said about these interesting issues, but these brief comments confirm the need for administrative law and procedure to deal with the issue of discretion.

Principles of the kind noted above are not the only ones guiding and constraining the exercise of discretion. It is usual to find in administrative law another set of principles which affect the reasoning process by which a decision is made, again especially where a discretionary element is present. One principle is that the authority must act in good faith. This is not expressly provided for in the Hungarian General Rules, although it might be thought to be implicit in the general duty on authorities to act lawfully $^{73}$. Another principle is that an administrative power ought to be used for the purposes for which it was conferred, taking into account all relevant factors and rejecting reliance on irrelevant ones. Related to this is an additional principle that the exercise of power must be not unreasonable, in the sense of really gross and serious unreasonableness. Unreasonableness can in turn be related to the principle of proportionality which has been developed in recent years by the European Court of Justice and several national courts, as a principle to be observed in administrative decision making.

The Hungarian General Rules do not deal with these matters expressly or directly and, indeed, it may be argued that such principles are best developed by the courts in the exercise of judicial review. That has been the pattern in many western jurisdictions, not least in France and the United Kingdom, where the principles of review have been created and expanded by the administrative courts in the former and the ordinary superior courts in the latter. The underlying idea is the principle of legality; but that principle, like any abstract principle, has to be interpreted and re-interpreted to give it meaning and content. In countries of Central and Eastern Europe, where judicial review as a significant means of supervision of the administration is in its early stages of development, and where it will take many years to create a mature jurisprudence, a good case can be made for incorporating the general principles discussed here into the code of administrative procedures.

\subsection{Giving Reasons}

An administrative act or decision must be accompanied by a statement of reasons ${ }^{74}$. In addition to various formal matters, the statement of reasons should include the facts and the evidence and the law that has been applied. The statement should also show why argument or evidence submitted by a party has not been accepted.

What constitutes adequate reasons is always a difficult question in administrative law which is often put before the courts for resolution. In western jurisdictions, a considerable body of doctrine has developed as to exactly what is to be included in reasons, and undoubtedly such issues will begin to appear in the Hungarian courts.

A study of licensing, made as part of the Administrative Justice Project, confirms the point that reasons can be more or less complete and informative, and that their content will be determined very much by the context. A good example is the decision to license a private school. Since refusal of a licence in Hungary would attract the attention of the media, such a decision is likely to be well documented and expansive

72 Administrative Justice Project.

73 Section 2.1.

$74 \quad$ General Rules, Section 43.1 
reasons may be expected ${ }^{75}$. Decisions which do not attract public attention are likely to be justified in more sparing terms. An administrative ruling should be conveyed immediately to the parties; where numerous parties are affected, provision is made for the public announcement or display of the ruling ${ }^{76}$.

\subsection{Recourse: Reconsideration, Appeal, Review}

Recourse from an administrative act or decision may take several forms: (i) an application may be made to the original authority itself; (ii) an appeal may be made to a superior administrative body; and (iii) a future appeal may lie to the courts on issues of law.

\subsubsection{Application to Reconsider}

The first of these is not described in the General Rules as an appeal, but as an application by the party to the authority to reconsider its decision on the basis that it infringes a law ${ }^{77}$. Upon receiving an application, the authority may amend or withdraw its ruling, subject to certain protections of third parties whose interests are affected. The authority is allowed to amend or withdraw its ruling only once, and generally it must be within a year of its making. The power to amend or withdraw may be restricted by law.

\subsubsection{Appeal to a Superior Authority}

The second form of recourse is an appeal properly speaking. However, we should note two preliminary points. The first is that the right to seek recourse is conferred on the parties to an administrative process and on persons, who are not parties, but whose interests are affected by the act or decision ${ }^{78}$. Both categories of appellant have open to them several forms of recourse. The second point is that the lodging of an appeal generally has the effect of postponing operation of the original act or decision unless the original authority orders that it have immediate effect ${ }^{79}$. The authority may so order in several situations, including where a law or decree allows for immediate effect.

The appeal is lodged with the original authority. Normally it should be lodged within 15 days of the act or decision unless the law provides otherwise. The original authority must pass the appeal on to a supervisory authority within eight days, although the former has the opportunity, before passing it on, to withdraw, modify, correct, or supplement the challenged ruling ${ }^{80}$. A supervisory body is normally a superior administrative authority; so, for example, a ministry is the supervisory body for matters dealt with at first instance by the head of local government or of the Budapest city administration, while the supervisory body for a ministry is the minister.

The appellant may present new facts and evidence, and the procedures to be followed in hearing the appeal are similar to those governing the primary decision. On hearing the appeal, the supervisory authority may

75 Details are set out in the Administrative Justice Project.

76 Sections 43 and 45.

77 Section 61.

78 Sections 62 and 72.

79 Section 63.

80 Section 65. 
confirm, change, or cancel the ruling ${ }^{81}$. The authority will have before it all the documents relating to the case, but if further evidence or material is needed for the proper determination of the case, the appellate body may either itself gather further information or return the case to the original with instructions that it deal with the matter afresh ${ }^{82}$. The appeal may deal with matters of merits and substance as well as legality. In cases where the original act or decision is held to be illegal, the appellate body may change or cancel the ruling and it may refer the matter back to the original authority for redetermination ${ }^{83}$. This last power is subject to certain qualifications contained in the General Rules and to others contained in specific laws ${ }^{84}$.

The right to appeal to a supervisory body is subject to certain limitations ${ }^{85}$. One situation where appeals are not allowed is where the government or a minister of the government has been involved in the primary action. Another such situation is where the law provides an appeal to the courts.

\subsubsection{Review by the Courts}

The third form of recourse is a request by a party to the court to review the legality, but not the substantive merits, of the act or decision ${ }^{86}$. This form of judicial review is only available if the appellant has first exhausted any rights of appeal to a superior administrative body ${ }^{87}$. The lodging of a request for judicial review does not automatically suspend operation of the original administrative decision ${ }^{88}$. The position is complicated: the administrative authority may declare that the decision is to have immediate effect; the party seeking review may request suspension and the matter will then be decided by the court in its discretion. If, on the other hand, the administrative authority does not so declare, the filing of a request for review will have the effect of suspending enforcement of the decision.

Where the illegality of the decision is made out, the court shall declare it to be invalid ${ }^{89}$. The court may also order the administrative authority to remake the decision in the light of the court's judgement. The court's remedies extend beyond a mere declaration of illegality to include the power to change the ruling, where specific laws so provide. The jurisdiction and powers of the courts in exercising review of administrative action will not be examined in detail here since it is the subject of Part II of this report. A party dissatisfied with the decision of a court at first instance may normally appeal to a higher court in accordance with the procedures of the civil courts.

\subsubsection{Comments}

In interviews conducted with officials and lawyers in Hungary, the point was often made that the appeal system is too complicated. In many cases there are in effect three forms of recourse, two within the administrative system and one to the courts; while within the court system itself, there is usually scope for

$\begin{array}{ll}81 & \text { Section 66.2. } \\ 82 & \text { Section 66.3. } \\ 83 & \text { Section 71.1. } \\ 84 & \text { Section 71.2. } \\ 85 & \text { Section 64. } \\ 86 & \text { Section 72.1. } \\ 87 & \text { Section 72.2. } \\ 88 & \text { Section 72.3 and 4. } \\ 89 & \text { Section 73.1. }\end{array}$


a second appeal. Added to this are the complications resulting from the different consequences which follow depending on whether the appeal is to a superior administrative body or to the courts. There is certainly a case for a greatly simplified and more systematic approach to recourse.

A second point which warrants special mention here is the relationship between internal administrative appeals and appeals to the courts. When the General Rules were first enacted in 1957, the underlying policy was that the administration ought to supervise itself through internal administrative appeals. Since that time, however, the policy has changed, with several amendments having been made to provide for and extend the role of the courts in supervising the administration. The result is that appeal to the courts is now a fundamental part of the General Rules; uncertainty remains, however, as to what role the two forms of recourse should have in the new administrative order. At present, recourse can be had to the courts only after any internal appeals have been exhausted or where specific laws allow direct recourse. This approach differs from that taken by some other countries in the region where judicial supervision is regarded as an alternative to internal administrative appeals.

Although the official position in Hungary is that judicial supervision follows on from an internal appeal, it appears from discussions with officials and lawyers that in practice increasing reliance is being placed on judicial supervision. It was said in those discussions that, since the amendments in 1990 providing for extended judicial supervision, the quality of internal supervision and the frequency of internal appeals have both dropped noticeably. The present position is unsatisfactory and a more considered and systematic approach needs to be taken.

\subsection{Conclusions and Matters for Consideration}

When the General Rules were adopted in Hungary in 1957, they were a major step forward in the history of Hungarian administrative law and administrative justice. Although there is little evidence to show how the rules worked in practice during the succeeding years, there is evidence that the General Rules were taken seriously by officials and that they constituted a commitment to creating an administrative culture in which effective administration was tempered by a concern for the interests of individual citizens. That commitment has been greatly strengthened in recent years by substantial amendments which not only modify aspects of procedure, but also open up the scope for appeal to the courts.

Nevertheless, forty years after the original enactment, the General Rules are in need of general overhaul. They are complex, too detailed on some matters, too sparse on others; the language (at least in translation) is stilted and artificial, and the general approach contained within the rules bears signs of the social and political climate of Hungary in 1957 rather than that of 1996. Hungary led the way in 1957 in Central and Eastern Europe when it passed the first administrative procedure code; the time may now be ripe for it to take the lead again by devising a new code suited to the needs of an administrator working in a democratic system and giving full protection to the rights of citizens.

Apart from the general sense of the administrative procedure code showing its age and its particular provenance, there are numerous specific points which need fresh consideration. Some of these points I have dealt with above, while others call for a more systematic analysis than can be given here. Among the matters which ought to be considered include the:

i. scope of the General Rules and the range of administrative actions covered by them;

ii. exclusion of areas of administration from the General Rules; 
iii. position of third parties who are affected by an administrative action without being directly subject to it;

iv. openness and transparency of the administrative process, especially in relation to the disclosure of information relevant to an act or decision;

v. adequacy of the notice and hearing rules;

vi. consequences for an act or decision when an appeal, whether within the administration or to the courts, is lodged;

vii. general role, purpose, and scope of internal appeals;

viii. relationship between internal appeals and review by the courts; and

ix. need for a general system of procedures for the making of normative acts.

\section{Poland}

\subsection{Poland's Legal Tradition}

Poland lost its independence in 1795 with the country being divided amongst Russia, Prussia and Austria. In 1918, after the Great War, Poland regained its independence and became a nation. Until 1918, the administrative law applying in Poland varied according to the three territorial divisions. Upon independence, the rebuilding of a national legal system was much influenced by the three systems amongst which Poland had for so long been divided; in the area of administrative law, the Austrian influence was particularly strong.

\subsection{The Administrative Law Background}

The first Polish administrative procedure code, based on the Austrian model, was passed in 1928. Administrative courts were also introduced, although they were not entirely new to the country. With the German invasion in 1939, the administrative procedures code fell into disuse, but was reintroduced in 1945. The administrative court system, however, was not included in the reforms and remained in abeyance until 1980 when it was revived by a separate law. As for the administrative procedure code itself, many parts of the law were not applied in practice in the years after 1945. In 1960, a new and more modern version of the code was adopted; its official title is the Code of Administrative Proceedings ${ }^{90}$, referred to here as the $C A P$. It was more modern in the sense that it was moulded more closely than its predecessor to the realities of a communist system in which social organisations had an important role to play and where grievances were considered best dealt with by the administration itself, rather than through external supervision by courts and other independent bodies.

In the post-Stalinist period, the Polish administrative court system was reintroduced to provide appeals outside the administration to a court, albeit on a rather limited basis. Following the demise of communism in Poland, various amendments have been made to the $C A P$, although it retains much of the essential structure created in 1960. A major reform of the administrative court system was introduced in 1995, with the main object of substantially extending the scope of the jurisdiction of the court over administrative acts and decisions.

$90 \quad$ Act of 1960. 


\subsection{Constitutional Principles ${ }^{91}$}

The Polish Constitution consists of two parts: one is the Constitution of 1952 as amended, the amendments of 1989 being especially important; the other part is the Constitution Act ${ }^{92}$ which is also known as the "Small Constitution". The Constitution of 1952 as amended contains a number of provisions of relevance to administrative law and procedure. The Republic of Poland is declared to be a democratic state "ruled by law"193; all administrative authorities have a fundamental duty to observe and comply with the laws of Poland ${ }^{94}$. A Commissioner for Citizens' Rights is created and citizens have a right to complain and to put their grievances before administrative bodies ${ }^{95}$.

\subsection{Overview of Administrative Procedures}

The Polish CAP follows broadly the same pattern as the equivalent Hungarian and Bulgarian codes. Although dating from 1960 and the communist period, the CAP has a modern feel about it and expresses ideas and concepts in clear simple language. While the original has been amended in important ways in recent years to bring it into conformity with contemporary ideas of administrative law, it nonetheless reflected a progressive approach to the subject. The CAP states a number of general rules and principles, which are discussed below, concerning participation and involvement of citizens in processes affecting them, the giving of reasons for decisions, and forms of appeal and review. It is similar to the Hungarian code in seeking to state procedural matters in considerable detail, rather than in broad outline as in the Bulgarian law. One interesting feature of the $C A P$ is that it deals at length with and supplies detailed procedures for the citizen's right to lodge with an administrative body a complaint about the way the authority has used its power, or a request that it should improve some aspect of its performance ${ }^{96}$. The $C A P$ also makes detailed provision for the settlement by an administrative authority of disputes between citizens, state bodies, or social organisations, by securing agreement amongst them; although it seems that in practice this course is not often followed ${ }^{97}$.

The CAP delineates the powers and duties of the Prosecutor to become involved in administrative processes $^{98}$. Another feature of special interest is the extensive provision made in the CAP for social organisations, which means, in effect, interest groups, to be involved, by way of initiation or participation, in administrative processes ${ }^{99}$. In matters of recourse from a decision at first instance, the emphasis is on appeals to superior administrative bodies. That familiar pattern in the approach of former communist

91 Since this Report was completed and in the proces of publication, a new Constitution has been adopted in the Republic of Poland. References in the text, however, are to the position which prevailed prior to such adoption.

$92 \quad$ Law No. 84 of 1992.

93 Article 1.

94 Article 3.

$95 \quad$ Article 86.7

96 These are dealt with in Chapters 2 and 3 of the CAP.

97 See Articles 28 and Chapter 8.

98 Chapter IV.

$99 \quad$ Article 31 
countries has to some degree been broken by the recent Supreme Administrative Court Act ${ }^{100}$ which extends significantly the scope for judicial supervision ${ }^{101}$.

\subsection{Background Principles}

The CAP sets forth a number of background principles which are meant to guide the actions of administrative bodies. The constitutional principle of legality is restated in Article 7 of the $C A P$ which imposes on administrative bodies a duty to safeguard lawfulness. Articles 7 to 13 establish duties to:

- do all that is necessary to elucidate the facts and to come to the right outcome in each case;

- take account of the interests of society and of its citizens;

- conduct processes in a way which will reaffirm the confidence of citizens in them and strengthen their legal awareness and their legal culture;

- inform the parties of facts and laws relevant to the recognition of their rights and obligations;

- make sure that the parties to administrative processes know and understand the relevant law;

- ensue the active participation of the parties at each stage of administrative proceedings;

- allow the parties to express their opinions on the evidence and material which the deciding authority has before it;

- explain to the parties the reasoning of the authority in order to encourage the parties to implement the decision without the need for coercive enforcement;

- act carefully and promptly, using the simplest means leading to the solution;

- encourage disputing parties involved in an administrative action to resolve the dispute by agreement.

Some of these principles are the subject of more detailed provision in the CAP while others are too vague and indeterminate to have much practical bearing; they do help, however, to define a certain approach to administrative justice.

\subsection{Scope of Administrative Action}

The general principle governing the scope of application of the $C A P$ is that it applies to individualised processes conducted by administrative bodies resulting in a decision ${ }^{102}$. The $C A P$ also applies in a number of other special cases, including the hearing of complaints and requests by administrative authorities as described in 3.4 above $^{103}$.

A wide definition is given to the kinds of authorities, the decisions of which come within the $C A P$; they include principally the institutions of central government, in all its forms including ministries, and local

\footnotetext{
$100 \quad$ Act No. 74 of 1995.

101 The role of the Supreme Administrative Court is discussed in Part II of this report.

102 Article 1

103 Article 2.
} 
and district authorities ${ }^{104}$. Certain kinds of acts are excluded from the $C A P$, an important example being the imposition of penalties in tax cases. The requirement that the process should result in a decision may at first sight suggest that certain actions of the administration, such as an investigation, fall outside its scope. It appears, however, that the concept of a decision is interpreted to include administrative actions generally. The possible exclusion of some areas of administrative action from the scope of the CAP was discussed with Polish officials and lawyers, but it seems that no practical disadvantages stem from the code's being restricted to decisions ${ }^{105}$.

One category of administrative actions which falls outside the scope of the CAP relates to the internal organisation and hierarchy of administrative authorities ${ }^{106}$. The $C A P$ also excludes certain routine acts, such as the entry into the register of a certain piece of information. An example is the entry into the register of the founding of a private school, once the necessary permit has been granted. the grant of the permit is an administrative act within the $C A P$, but the entry into the register is not. A refusal, however, on the part of the official to make the entry would be an administrative act ${ }^{107}$.

In many cases the distinction between administrative actions which fall within the ambit of the $C A P$ and those which do not will be easy to determine. The position, however, can be complicated, with some elements of a course of administrative activity covered and others excluded. A good illustration of the complexity can be seen in a recent case study in Poland of inspections of restaurants on health and safety grounds ${ }^{108}$.

The CAP does not apply to the making of normative acts (that is, secondary legislative rule-making). The procedures governing normative acts are specified in particular statutes, if they are specified at all, although the Local Government Act 1996 sets out general procedures for rule-making by local government. The comments made above in relation to the Hungarian General Rules apply equally here; in short, there is a strong case for a statement of general procedures governing the making of subordinate or secondary legislation.

\subsection{The Course of an Administrative Process}

An administrative process may be initiated by the relevant authority of its own initiative or by a party ${ }^{109}$. Anyone whose legal interest or duty is affected by the process, or who asks that certain action be taken by the authority with respect to a legal interest or duty, may be a party ${ }^{110}$. The term "party" includes social organisations as well as natural persons; social organisations are, broadly speaking, interest groups. Once an action has been started, various conditions are imposed by the $C A P$ with respect to such matters as the giving of notice to other interested persons or organisations, the gathering of evidence and the summoning

\footnotetext{
$104 \quad$ Articles 2 and 5.2.

105 It should be noted that the jurisdiction of the Supreme Administrative Court is defined more broadly. It may review decisions and other acts or activities, etc.: see Act on Supreme Administrative Court (1995), Article 16.

106 Article 3.3.

107 For further discussion of this point, see Administrative Justice Project.

108 Ibid.

109 CAP Article 61

$110 \quad$ Article 28.
} 
of witnesses, conflicts of jurisdiction or competence, intermediate or interlocutory matters, and the making of records (or protocols) at each stage of the process.

Witnesses are to be examined from time to time in the presence of the parties, if they so choose, and in some cases a trial may be held to deal with all the evidence and the witnesses at the same time. Provision is made for the parties involved in an administrative action to reach a settlement, although this procedure is not often invoked.

Once a decision has been made, a party may lodge an appeal against it to a superior administrative authority ${ }^{111}$. In some cases, whether the first instance decision is made by a superior authority, there is no appeal from the decision. The form of recourse open in such cases is a request to the superior body itself to reconsider the case ${ }^{112}$. The appeal provisions under the $C A P$ are internal to the administration; these are supplemented by external appeals to the Supreme Administrative Court which may adjudicate on the legality of administrative decisions ${ }^{113}$.

\subsection{Participation: Notice, Disclosure, and Hearing}

The relationship between openness on the one hand and notice, disclosure, and hearing on the other hand was examined in the earlier section on the Hungarian General Rules. It was suggested in that discussion that, while openness may be increased through various mechanisms, participation by interested parties in administration processes is one of the most fundamental. The following analysis shows that participation through notice, disclosure, and hearing is reasonably well provided for in the Polish CAP.

\subsubsection{Participation}

A general duty is imposed on administrative bodies to ensure the active participation of the parties at each stage of the proceedings ${ }^{114}$. This general duty is made more specific in a number of ways as the following analysis shows.

\subsection{2. $\quad$ Notice}

The CAP sets out a number of rules regarding the giving of notice. Once an action has begun, notice should be given by the administrative authority to interested parties and organisations ${ }^{115}$. Parties should be informed of the time and place at which witnesses or experts will give evidence, or where an inspection will take place ${ }^{116}$. Where a trial is planned, interested parties should be notified ${ }^{117}$. The exercise by parties, where interests are affected by an administrative decision, of their rights to participate often depends on their being notified that an act is being done or a decision being made. The notice requirement in

111

112

113 Discussion of the appeal procedures can be seen in the second Part II of this study.

114 Article 10.

115 Article 61.4.

116 Article 79

117 Article 90
Article 127.

Article 127.3. 
Article 61.4 of the $C A P$ is important in helping to ensure that parties are able to exercise those rights. One difficulty with the notice requirement is that it may not always be clear who is a party and, therefore, who should be informed. While the circle of persons whose interests may be affected will often be narrow, in some cases the decision as to how far the circle extends will be a matter in the discretion of the authority. As in the Hungarian General Rules, the position of third parties, who have an interest in administrative proceedings but are not the direct subjects of it, is not adequately treated.

\subsubsection{Disclosure}

In addition to the general right to participate noted above, Article 10 of the $C A P$ confers on the parties the right to offer their opinions on the evidence and materials pertinent to the case. This right must implicitly carry with it a correlative duty on the authority to disclose the evidence and materials. The rather general provision in Article 10 is added to in other parts of the $C A P$ by allowing the parties access to the files in a case, although in practice any inspection is not usually conducted until after the decision has been made ${ }^{118}$. Beyond these specific duties, there is no general and explicit statement of principle in the CAP imposing on administrative bodies a duty of disclosure of information.

Where the disclosure of information in administrative proceedings is provided for, it is subject to the condition that the information should not include state or service secrets, two concepts defined by the law on the Protection of State and Service Secrets ${ }^{119}$. State secrets refer to information the disclosure of which may jeopardise the defence, security, or significant interest of the state ${ }^{120}$. Service secrets refer to information, other than state secrets, obtained by an officer in the course of performing his functions in an administrative organisation, where the disclosure could jeopardise the interest of the society, a legitimate interest of the authority, or a citizen ${ }^{121}$. The Protection of State and Service Secrets law contains extensive provisions elaborating these concepts and specifying the duties of officials in relation to them. The general point is that state and service secrets may not be disclosed unless disclosure is authorised by law in particular contexts. The law on the protection of state and service secrets is under review, but clear proposals for reform have yet to be agreed upon.

\subsubsection{Hearing}

The general duty under Article 10, of the $C A P$, conferring on the parties a right to participate, provides the basis for the parties being heard at various points in an administrative process. This right is supplemented by the express requirements that the parties be given the opportunity to express their views in relation to any evidence and other materials before the authority. This includes disclosing to the parties the protocols or reports prepared by the authority at different stages during the process ${ }^{122}$. Where witnesses are to be examined in the course of an administrative decision, the parties have a right, to be informed of the time and place, and to participate by submitting their own evidence or by questioning witnesses, experts, or other parties ${ }^{123}$.

\section{$118 \quad$ Articles 73 and 74.}

119 Act No. 65 of 1982.

120 Article 2.

121 Article 3.

122 On the preparation of protocols, see Article 67.

123 Article 79.2. 
Provision is also made for the participation of the parties where a trial is held. Trials may be required under a specific law or regulation; they are also required when necessary to accelerate or simplify the proceedings, or when to do so would have an educational benefit. Administrative trials are commonly required by law and are often conducted in areas involving environmental issues, housing, and public expropriation $^{124}$. Trials are also required when they are necessary to reconcile the interests of parties in conflict, or in order to clarify the matter in issue by calling witnesses or experts, or by conducting an inspection of the site. At a trial, the parties may offer clarification of issues, file petitions, proposals, and complaints; they may also present evidence ${ }^{125}$.

\subsection{Legal Representation}

The parties to an administrative decision may act through their legal advisers unless the nature of the action requires personal participation ${ }^{126}$. However, very little resources are available to provide citizens with legal aid and most parties are unrepresented, although a lot depends on the kind of action in issue and the financial means of the parties. Factory owners applying for a license to discharge waste will nearly always be represented, while cafe owners subject to inspections will not ${ }^{127}$.

\subsection{Bias and Impartiality}

Detailed provision is made in the $C A P$ for officials being excluded from an administrative process where there is bias or a risk of bias ${ }^{128}$. The provisions divide broadly into two categories: one where the official or a close relative of the official has a personal connection of some kind with a party ${ }^{129}$; the other category is where the official or authority has a financial interest in the issue ${ }^{130}$.

These detailed provisions may be seen as part of a more general concern that officials and agencies should defend the integrity of the legal order ${ }^{131}$. Officials and agencies are also required to take all necessary steps to clarify the facts of the case and to reach a resolution which pays due regard to the interests of both society and the parties. As noted earlier, officials and agencies should conduct proceedings in such a way to inspire confidence in the administration and promote the legal awareness and good behaviour of citizens $^{132}$. As Professor Biernat has written : "It can be inferred from these norms that administrative agencies should be guided only by those considerations which are relevant by law in order to reach a decision" $" 133$.

$\begin{array}{ll}124 & \text { Article } 89 f f . \\ 125 & \text { Article } 95 . \\ 126 & \text { Article } 32 . \\ 127 & \text { Administrative Justice Project. } \\ 128 & \text { Article 24 ff. } \\ 129 & \text { Article 24. } \\ 130 & \text { Article 25. } \\ 131 & \text { CAP, Article 7. } \\ 132 & \text { Article 8. } \\ 133 & \text { Administrative Justice Project. }\end{array}$




\subsection{Constraints on the Decision Process}

Administrative authorities are enjoined to act carefully and promptly, using the simplest means leading to the desired outcome ${ }^{134}$. The duty to act carefully is a reminder to officials that they ought to aim at accuracy in their decisions. The duty to act promptly could be the basis for a more specific duty of timeliness, the idea being that an administrative decision should be made without undue delay. Timeliness is a concept which has some prominence under the Federal Administrative Law of the United States ${ }^{135}$.

Apart from these rather general provisions, the CAP does not deal with other possible constraints on the decision process; nor does it offer guidance concerning the exercise of discretion. The earlier comments made in relation to the Hungarian General Rules apply equally here.

It may be worth repeating the point that general legal principles guiding and constraining the exercise of discretion are often left to be devised and expanded by the courts in the exercise of judicial supervision. This general comment applies to Poland. Some standards relating to the exercise of discretion can be found in the Constitutions, the CAP itself, and specific laws; of particular importance are : the rule of law and the principle of legality ${ }^{136}$, the general principles of $C A P$ as set out above, and of course the substantive provisions contained in specific laws.

The point was made by one senior professor of law that in practice Polish laws generally specify in detail the conditions to be met and the criteria to be applied in exercising administrative powers. Such detailed criteria reduce the scope of discretion and remove some of the threats of arbitrary administrative action. Indeed, it appears from interviews with officials of the Ministry of Justice, two reforms were in progress: firstly, amendments to $C A P$ would be proposed to tighten the procedures governing the exercise of discretion and, secondly, that in the drafting of substantive laws greater efforts should be made to specify the criteria of decision-making and thus to reduce the scope for discretion.

It should also be noted that the Supreme Administrative Court in exercising judicial supervision of administration is in the course of constructing and extending general principles, such as equality before the law and the consistent treatment of cases.

\subsection{Giving Reasons}

A general duty on an administrative authority to give reasons for its decisions is stated in Article 11 of the CAP. The duty is expressed in the form of an obligation on the authority to explain to the parties its reasoning in the case in order to secure compliance by them with the decision without having to invoke sanctions. More detailed provisions are laid down in Article 107 of the CAP which stipulate the matters to be included in the reasons. Apart from certain formal information, the reasons should include the legal basis for the decision and the facts on which it is founded. The legal justification should refer to the applicable law in some detail, including quotation of the provisions relied on. The factual part should include the facts found to be proved, the evidence relied on, and the reasons for not relying on other evidence where that is the case. These requirements may be relaxed where the security of the state or the

134 Article 12.

135 For discussion of timeliness, see W. F. Fox, Understanding Administrative Law (Matthew Bender, New York, 1992).

136 Constitutional Provisions, Articles 1 and 3. 
social order is at stake. They equally may be dispensed with where the decision taken is that sought by the party or parties ${ }^{137}$.

\subsection{Complaints and Requests}

One interesting feature of the Polish $C A P$ which does not appear in the procedural codes of Hungary or Bulgaria is a detailed statement of the rights of citizens and social organisations, such as interest groups, to lodge complaints and requests with administrative authorities. The right of citizens to petition government and the institutions of government is deeply entrenched in the legal and political culture of central European countries.

"Complaints" as defined in the CAP relate to allegations of negligence, impropriety, illegality, undue delay, or bureaucratic settlement of cases ${ }^{138}$. The $C A P$ states where complaints are to be lodged and the authorities competent to deal with them ${ }^{139}$. For example, the President of the Council of Ministries deals with complaints about the actions of a council of a commune, while the Council of Ministers considers complaints against a minister. In some cases, where the matter complained of is not the subject of an administrative action, the very lodging of the complaint has the effect of initiating such an action ${ }^{140}$. The complaint will then be examined in the course of the action. The authority to which a complaint is made is expected to settle it without delay and within one month $^{141}$; the method of settlement should be notified to the complaining party.

A "request" as defined in the CAP may be made by a citizen to an administrative authority that some specified part of its work should be improved. The request may relate to such matters as the organisation of the authority, an improvement in the legality of the authority's actions, or the prevention of abuses ${ }^{142}$. Requests are lodged with the relevant authority which is required to deal with it within a fixed time. If requests are not dealt with to the satisfaction of the requesting party, a complaint may be lodged according to the procedure described above ${ }^{143}$.

Special provisions are included in the $C A P$ for complaints and requests by the press and other social organisations ${ }^{144}$. Provision is also made for administrative authorities receiving and listening to citizens who wish to lodge complaints or make requests ${ }^{145}$. The recognition and settlement of complaints and requests against administrative bodies is supervised by the President of the Council of Ministers, while those directed at courts are supervised by the National Judiciary Council ${ }^{146}$.

137 CAP Article 107. The dispensation does not apply when the decision is an adjudication on a matter disputed between the parties; nor does the dispensation apply to decisions issued on the basis of an appeal.

$138 \quad$ Article 227.

139 Articles 228 and 229.

140 Article 233.

141 Article 234.

142 Article 241.

143 Article 246.

144 Article 248.

145 Article 253.

146 Article 257. 


\subsection{Administrative Appeals}

The $C A P$ provides for appeals from an administrative decision to a superior administrative body, although alternative appeal arrangements may be contained in other substantive laws ${ }^{147}$. After any internal appeals have been exhausted, an action may be brought before the Supreme Administrative Court on questions of legality ${ }^{148}$. Here I shall deal only with administrative appeals under the $C A P^{149}$.

Administrative bodies are divided into three categories: state administration, superior, and supreme. Without listing the various categories here, the general point is that an appeal lies from state administrative authorities to superior administrative bodies ${ }^{150}$. To take an example, an appeal from the decision of the head of a district office of central administration lies to the Voivod (meaning governor of the province), while an appeal from a Voivod lies to the Minister.

The main qualification to this appeal structure is that a decision made by a superior state authority cannot be appealed against; instead the dissatisfied party may request the authority itself to reconsider the case ${ }^{151}$. Provision is also made in the $C A P$ for complaints being lodged against interim or interlocutory decisions prior to or in the course of reaching a final decision ${ }^{152}$.

When an appeal is made to a superior authority, it is first submitted to the original body. In some cases the original authority may deal with the matter itself and issue a new decision ${ }^{153}$; but normally the appeal, together with the file, is passed on to the superior authority within a strict time limit. The superior authority may obtain more evidence and materials if it considers it necessary ${ }^{154}$.

Once a decision has been made by an administrative authority, an interested party has a short period (14 days) within which to appeal. The decision should not be implemented or enforced during that period. If a party does appeal within the fourteen day period, enforcement or implementation of the decision is further suspended until the appeal has been determined ${ }^{155}$. There are important exceptions to this principle of suspension. The original authority may include in its decision, or add at some later time, a requirement of immediate enforceability on stated grounds, such as the protection of health or life, the national economy, or an exceptionally important interest of a party ${ }^{156}$. Provision for immediate enforceability may also be made in specific parliamentary laws ${ }^{157}$.

The powers of the superior authority on an appeal are considerable. It may uphold the original decision, reverse it in full or part, or refer the issue back to the original authority for reconsideration ${ }^{158}$. The

$147 \quad$ Article 127.

148 See Act on the Supreme Administrative Court, Article 34.

149 Research conducted for the Administrative Justice Project has shown that appeals are made against less than one per cent of administrative decisions.

150 Article 17

$151 \quad$ Article 17.3.

152 Article $141 \mathrm{ff}$.

153 Article 132.

154 Article 136.

155 Article 130.

156 Article 108.

157 Article 130.

158 Article 138. 
appellate body should not make a decision detrimental to the interests of the appealing party unless the decision appealed against clearly violates the law or the interests of society ${ }^{159}$.

Although this report does not deal in detail with judicial supervision of the administration, it is worth emphasising the point noted above that an appeal to the Supreme Administrative Court may be sought only after internal administrative appeals have been exhausted ${ }^{160}$. In cases where there is no internal appeal, recourse may be had to the courts directly and without delay. It is also to be noted that the kinds of administrative activity which is subject to appeal by the Supreme Administrative Court is considerably wider than "decisions", the concept by which the scope of the CAP is defined. Whether this discrepancy will have any practical consequences is not yet clear.

\subsection{Conclusions and Matters for Consideration}

Since its enactment in 1960, the Polish Code of Administrative Proceedings has been amended and re-amended in response to changing political ideas and social conditions. The result is a code of procedure which is based on the general principles of administrative law and administrative justice which are widely recognised across Europe. There is a clear recognition that administrative government should be conducted according to the basic principle of legality and in accordance with other values deriving from the rule of law, open government, and justice to individual citizens and interest groups. The Code of Administrative Procedures is well-constructed and, in English translation, readily comprehensible.

There are, however, several issues to which attention ought to be drawn. One is the scope of application of the CAP. The restriction of the code to "decisions" is, on its face, too narrow and, although decisions may be taken in a very broad sense, there are areas of administrative activity, such as inquiries and investigations, which are not covered. The position of normative acts also should be addressed and a suitable procedural regime introduced. Normative acts are not included in the CAP or subject to any general procedural code.

Secondly, the rules governing disclosure of evidence and materials by the administrative authority to interested parties could be improved upon. There is no clear and express statement of a general duty of disclosure, nor are there adequate detailed rules covering specific situation. Disclosure of information in specific cases is part of the wider issue of freedom of information, and the enactment of a general freedom of information statute in Poland would now be timely. Such legislation should include a revision of the current laws governing the withholding of information relating to state and service secrets.

A third point which ought to be given some thought is the general issue of internal administrative appeals and supervision. The Polish approach as expressed in the CAP reflects the view that administrative action is best supervised by the administration itself. That view may still be valid but, if it is, it may be for reasons different from those which were convincing in 1960. It may be that mechanisms of supervision internal to the administration can make an important contribution to good quality administration. That issue, however, needs to be examined directly and it may be that the kinds of mechanisms needed are not the same as those now in the code of procedures.

Following this summary, the specific points for further consideration include the:

159 Article 139

160 See footnote above. 
i. scope of the CAP, that is the kinds of acts and decisions which ought to be included within it, in particular the range of acts which are not decisions;

ii. procedures which ought to govern the making of normative acts;

iii. appropriateness of a clear and specific provision for the disclosure of evidence and materials by administrative bodies; this should be considered in the broader context of freedom of information and the need for general legislation on the issue;

iv. suitability of internal appeal procedures as presently provided for, and the relationship between such internal appeals and external forms of appeal and review;

v. role of the Prosecutor in the field of public law; and

vi. general structure of the administrative procedure code and the question whether it should be re-drafted in a way which is more appropriate to the current legal system of Poland.

\section{Bulgaria}

\subsection{Bulgaria's Legal Tradition}

Bulgaria won independence from the Turks in 1878. After liberation, the country underwent a period of legal change and reform which was much influenced by various legal traditions including Austria, German, France, Hungary and Italy. After the Second World War, Bulgaria became a communist state and was heavily influenced in all aspects of life, including the legal, by the Soviet Union. Since the end of communism in 1989, Bulgaria has again gone through a period of great legal reform, including the adoption of a new constitution in 1991. These reforms are continuing and are not yet complete. The influences on this occasion are once again the major countries of Western Europe, with membership of the Council of Europe and potential membership of the European Union also exerting significant influence ${ }^{161}$.

\subsection{The Administrative Law Background}

After independence in 1878, the Bulgarian system of administrative law developed rapidly, with the northern part of the country being much influenced by the German approach and the south by the Russian. Administrative courts were soon created in both parts of the country. The two systems united in 1885 to form one court which gradually evolved from a body with limited jurisdiction and non-professional judges to a full administrative court. A major new law governing the membership and powers of the administrative court was passed in 1920; however, in 1942, under German influence, the court's powers were reduced and the access of citizens to it largely removed. During this period the government increasingly sought to limit the role of the court in reviewing administrative action. One device used to this end was to govern by decrees which were outside the court's supervision.

After the war and the communist take-over, judicial review of administrative action was no longer acceptable and the administrative courts were finally abolished in 1947. To the extent that there was to be any judicial supervision of the administration, it would be performed by the civil courts.

161 Strenuous efforts are being made within the secretariat of the Council of Ministers to ensure that Bulgarian law is in conformity with the standards set by the European Commission for countries aspiring to EU membership. 
By 1970, however, the political climate had begun to change. The first code of administrative procedure was erected, together with a separate law on administrative penalties. The Administrative Procedure Act (referred to as the $A P A$ ) introduced a general set of procedures to be followed by administrative bodies in relation to individualised actions. The $A P A$ also introduced, or perhaps reintroduced, review by the ordinary civil courts of administrative action. Important amendments were made to the APA in 1979, 1989, and on several occasions since.

The Bulgarian Constitution of 1991 makes provision for the creation of special administrative courts, to be known as the Supreme Administrative Court ${ }^{162}$. Further provision is made for the Supreme Administrative Court in the Judicial System Act ${ }^{163}$, but so far the court has not been created. The reasons for the delay are not clear, but it now appears that the President has been appointed and it is being suggested that the court will be in operation in 1997. No freedom of information legislation has been enacted, nor is there much prospect of it in the foreseeable future, although a decree attempting to define state secrets was proclaimed in $1950^{164}$. Statutory reforms are being made to the office of the Prosecutor, but the idea of an ombudsman has so far won little support from the government.

\subsection{Constitutional Principles}

The Constitution of Bulgaria, adopted on 12 July 1991, has several provisions relating to administrative law and procedure. Article 5.4 provides for the direct applicability of international instruments once they are promulgated by the State of Bulgaria. This means that the procedural due process, as well as other provisions of the European Convention on Human Rights, should apply directly in domestic law. A Constitutional Court has been created which has jurisdiction to decide on the constitutionality of laws and other acts of the National Assembly and Court of Ministers ${ }^{165}$.

The Constitution also specifies that there shall be a Supreme Administrative Court ${ }^{166}$ and that the courts "shall supervise the legality of the acts and actions of the administrative bodies"167. Article 120 goes on to say that citizens and legal entities shall be free to contest any administrative act which affects them, except those specified expressly by law. Jurisdiction is conferred on the Supreme Administrative Court to provide "supreme judicial oversight as to the precise and equal application of the law in administrative justice" ${ }^{168}$. The Supreme Administrative Court is given authority to rule on the legality of acts of the Council of Ministers, individual ministers, and other acts as established by law ${ }^{169}$.

Another important provision in the Constitution concerns the Prosecutor's Office. Since 1989, the Prosecutor's main functions have been restricted to criminal law; the office, however, retained a special duty to ensure that legality is observed "by taking part in civil and administrative suits wherever required to do so by law"170.

162

163

164

165

166

167

168

169

170
Constitution, Article 125.

Law No. 59 of 1994.

List of Facts, Information and Objects which Represent State Secrets (Decree No. 31 of 1990).

Article 149.

Article 119.

Article 120.

Article 125.

Article 125.2.

Article 127. 


\subsection{Overview of Administrative Procedures}

The first thing to note is that, compared with the procedural codes of Hungary and Poland, the Bulgarian $A P A$ is quite short. While the Hungarian code runs to 98 sections and the Polish to 269 sections, the Bulgarian has a mere 56. The difference in length may reflect a somewhat different philosophy, for while the Hungarian and Polish codes purport to be as comprehensive as possible in dealing with procedures, Bulgarian tends to state more general principles with the details being left to be determined by the administrative officials and courts.

The virtue of this approach is that the important and permanent principles are stated clearly and simply, and can be moulded to fit different contexts. These are, however, major drawbacks. In the first place, the idea of stating general principles and leaving it to courts and officials to interpret and apply them may be a peculiarly western, possibly Anglo-American, approach which neither finds a natural home in the legal traditions of Eastern Europe, nor suits the particular needs of a new democracy.

The combination of these two factors, may lead to the conclusion that at this stage in its development of a modern system of administrative law, Bulgaria needs a rather more detailed and comprehensive procedural code. This would not only relieve legislators, officials and courts of the need to fill-in the general principles in different contexts of administration, but would also reduce a wide and perhaps unwisely conferred discretion. A second problem with the Bulgarian approach is that the APA either deals with some principles inadequately or omits them altogether. The disclosure of information is an example of the former, while the omission of various principles such as proportionality illustrates the latter.

Subject to these observations, the Bulgarian APA caters for the most important elements of administrative law and procedure. The $A P A$ applies generally to administrative acts of an individual nature made by administrative bodies, with some exceptions. The $A P A$ limits the jurisdiction of any administrative body to the exercise of those powers conferred by law and it requires officials to act impartially. Some limited provision is made in relation to the disclosure of information for the purposes of an administrative act, the giving of notice to parties, and the participation of interested persons at any hearing. Administrative acts must be supported by reasons, and provision is made for appeal to a superior administrative body on the law and the merits, with the possibility of further appeal to the courts on matters of legality.

Now of course here, as elsewhere, the gap may be substantial between the rules as they appear in the statute book and the practical reality of those rules in influencing official behaviour or protecting citizens. However, amongst the Bulgarian lawyers, scholars, and officials interviewed in the course of this study, a noticeably sceptical attitude prevailed on both counts. The basis for the scepticism seems to be a combination of factors such as the lack of knowledge and training within the civil service, the apparently constant state of change and instability at the political level, and the ignorance of citizens and lack of advice available to them regarding their rights in administrative contexts. Some evidence for this scepticism can be seen in the detailed studies conducted in the Administrative Justice Project.

\subsection{Scope of Application of the APA}

The general principle of the $A P A$ is that it applies to acts of an individualised nature ${ }^{171}$. The $A P A$ is a general law which may be added to or subtracted from in specific areas of law ${ }^{172}$. To form a complete picture of administrative procedures, one would need to examine both the APA and any other laws specific

171

172
Article 2.

See Article 1.1: "in so far as no other act or decree establishes special rules". 
to different areas of administration. Individualised acts are to be distinguished from normative acts, the latter being in the nature of legislative or quasi-legislative rule-making. Normative acts are not covered by the APA but are subject to the Law on Normative Acts ${ }^{173}$. While I shall not here offer a detailed analysis of the Law on Normative Acts, it should be noted that the statute is somewhat fragmentary and does not stipulate detailed procedures for the subordinate legislative process.

Individualised acts are defined according to two sets of criteria: first, the character of the official or authority and, secondly, the effects of their actions. As to the first, administrative acts for the purposes of the APA are those acts issued by: leaders of official organs; mayors of municipalities; majors of localities; other organs of municipal government; other expressly empowered economic and public $\operatorname{organisations}^{174}$. This definition does not include the acts of the President or of the Council of Ministers ${ }^{175}$.

According to the second part of the definition, administrative acts are covered by the APA if they create rights and obligations or affect the rights and interests of citizens or organisations ${ }^{176}$. This last feature gives "acts" a wide scope since it is enough that the administrative act affects rights and interests. It is important to note that the refusal to do an act itself constitutes an administrative act for the purposes of the $A P A^{177}$. Also it is interesting to note that "act" is a wide concept which includes acts which are not decisions. This means that administrative acts preliminary to or in some way incidental to decisions or final acts would themselves be administrative acts for the purpose of the APA. The issuing of documents, or the refusal to issue documents which are significant for the recognition, exercise, or extinguishing of right and duties are also deemed to be "acts" for the $A P A^{178}$.

Certain kinds of acts are excluded from the operation of the APA. Acts concerning defence and security, socio-economic development and pricing, and acts which are of internal application to an organisation are among the excluded categories ${ }^{179}$.

Another category of exclusion are acts demonstrating administrative violations and acts imposing administrative penalties. This is a significant area of exception which is covered by a separate law - the Statute on Administrative Violations and Penalties. The distinction between administrative acts within the $A P A$ and those which are excluded as demonstrating violations or imposing penalties may be illustrated in this way: suppose that a factory was held to be violating standards governing the discharge of effluent into a waterway. While the setting of the standards in the first place is likely to be an administrative act within the $A P A$, the decision that the standard is being violated is outside the APA since it concerns a decision showing a violation or imposing a penalty. The distinction between administrative acts and the imposition of penalties by an administrative body may be sound, but it is not clear why the two parts should be dealt with by different laws, since each appears to raise similar issues of administrative procedure.

173

174

175

176

177

178

179
Act No. 45 of 1972.

Articles 1.1 and 2.1.

Article 2.

Article 2.

Article 2.1.

For a fuller account of the scope of application of the APA in the range of administrative contexts, see the Administrative Justice Project.

Article 3. 


\subsection{Background Principles}

In marked contrast to both the Hungarian and Polish administrative procedure acts, the Bulgarian APA does not begin with a statement of general background principles, although certain important principles are stated throughout the Act. The one principle of significance, as noted above, is the general background principle under Article 5.4 of the Constitution. Under this article, Article 6 of the European Convention on Human Rights, which provides for procedural due process and other values, is made applicable in national law.

\subsection{The Course of an Administrative Action}

The Bulgarian APA does not state in detail the procedures to be followed in administrative acts and decisions at first instance. There are, however, several provisions which set the parameters within which first instance acts are done. Administrative bodies may only perform such administrative acts as they are empowered to do so by law ${ }^{180}$, and an administrative body shall act independently in discharging its duties. The competence of administrative bodies to issue administrative acts is to be determined by particular laws.

An act may be initiated by the administrative body or at the request of an individual or organisation or at the request of the Prosecutor ${ }^{181}$. The Office of the Bulgarian Prosecutor is of special interest, since the Prosecutor has a duty to be involved in administrative activity and to ensure that administrative bodies exercise their powers according to law ${ }^{182}$.

Administrative acts must be made within seven days of the action being commenced, subject to extensions in special circumstances, such as the need to gather evidence or to allow other persons or interest groups to be represented ${ }^{183}$. Evidence may be gathered in whatever ways the administrative body considers appropriate, subject to specific laws on the matter ${ }^{184}$. The administrative authority has power to require social organisations and individuals to produce evidence and documents ${ }^{185}$. The $A P A$ does not deal in any detail with questions such as the summoning and hearing of witnesses. It does, however, make provision for the use of experts by the authority to gather and evaluate evidence and materials.

Provision is made in the $A P A$ for the participation of persons and organisations with rights or interests at stake, and for the giving of reasons and the communication of those reasons to interested parties. The APA does not require the disclosure by the authority of evidence or materials to the parties involved in an administrative action. An aggrieved party may appeal to a superior administrative authority, and, having exhausted that avenue of recourse, may seek recourse in the courts on issues of legality.

\section{$180 \quad$ Article 6.}

181 Article 7.

182 The role of the prosecutor in public law actions is discussed in Part II of this report.

183 Article 13

184 The Civil Procedure Code (1952), Article 44, deals with issues of administrative procedures.

185 Article 12. 


\subsection{Participation: Notice, Disclosure and Hearing}

\subsubsection{Participation}

The general principle expressed in the $A P A$ is that the parties should be given the chance to participate in an administrative process at all stages from the very beginning to the final issuing of the act. Article 11 of the APA expressly states that the explanations and objections of interested parties and organisations must be discussed before issuing an act. This article has been interpreted by the Postanovlenie of the Plenum of the Supreme Court (4/ 1976) to mean:

"It is a principle that the parties are given the opportunity to participate during the whole administrative procedure, from its beginning to the issuing of the administrative act. That is why there is a duty for the administrative authorities to give notice to the parties of the beginning of the procedure. The same principle stands behind the duty of the authorities to give an opportunity to the parties to state their arguments and complaints, point out and provide evidence, and taken as a whole to protect their rights and legal interests which might be affected by the act".

While the general principle stated in Article 11 provides for the participation of interested parties, the APA does not develop the principle in detail, nor does it create a duty of disclosure to the parties by the authority. The specification of detailed rules covering those matters is left to particular laws; indeed various specific laws do contain more detailed procedures for the conduct of administrative acts. The laws on environmental protection are a good example of more detailed and more exacting procedures. It is hard to believe, however, that all specific laws will have detailed provisions on these matters and in many areas no provision is made for notice, disclosure, and hearing beyond the limited requirements of the $A P A$. Subject to these general remarks, a few more specific points may be made about notice, disclosure, and hearings.

\subsubsection{Notice}

Article 7 imposes a clear duty on the administrative body to give interested individuals and organisations notice of the commencement of a procedure. No detail is given as to precisely what form the notice should take or what it should contain.

\subsubsection{Disclosure}

As noted above, no express provision is made in the APA for the disclosure of evidence and documents, and such a duty is considered not to be implicit in the general principle of Article 11. The precise extent and content of the duty remains somewhat unclear. Disclosure then depends either on specific laws or is left to the discretion of the administrative body. The failure to provide for disclosure of materials relating to the administrative act at issue is a serious gap in the APA. Moreover, there is no more general freedom of information legislation and discussion on such issues appears to be in its early stages.

\subsubsection{Hearing}

It is clear that the right to a hearing on the part of interested parties is implicit in Article 11. The APA, however, contains no details as to what form the hearing should take. There is some advantage in leaving the precise form of the hearing either to specific laws or to the discretion of the authority, since the scope 
and nature of the hearing is likely to vary according to the context. The disadvantage, however, is that important matters of this kind may then be dealt with in different ways depending on the authority. It is likely, indeed, that left to its own devices, an authority will naturally take a minimalist approach.

However, to take one concrete example, a study of administrative action in the environmental sphere has shown that the general provisions of the $A P A$ and more detailed requirements under the law on the Preservation of the Environment covering notice, disclosure and hearing are followed conscientiously by administrative officials in this area ${ }^{186}$. The holding of a public meeting at which views could be expressed was publicised on radio and by advertisement. Materials and evidence gathered by an independent expert on the environmental impact of certain practices of discharging effluent were made available to the public. A report was then prepared by the expert on the opinions expressed at the public meeting.

\subsection{Legal Representation}

A party with an interest in an administrative action may authorise other persons or organisations to represent them in the proceedings ${ }^{187}$. This section of the APA opens the way for legal representation of a party, although it should be noted that in practice few parties have legal representation.

\subsection{Impartiality and Lack of Bias}

Bias on the part of an official is expressed in Article 9 of the APA in two concepts: one is based on the official having a vested interest in the outcome; the other is based on the relationship between the official and interested parties which may give rise to doubts as to the former's impartiality. This is an acceptable way of expressing the impartiality principle and would appear to cover the same ground as similar principles in western jurisdictions. Empirical studies of a range of administrative processes in Bulgaria found no evidence of dissatisfaction by the parties regarding the impartiality and good faith of officials ${ }^{188}$.

\subsection{Constraints on the Decision Process}

The Bulgarian APA does not deal with issues such as the exercise of discretion and the various constraints upon it. Here the reader is referred to the comments made in relation to the Hungarian General Rules in Section 2.11. Those comments apply equally to the Bulgarian APA. This means that matters such as the fettering of discretion, its sub-delegation, or abdication are not dealt with in the $A P A$. It also means that doctrines relating to relevance, reasonableness, and proper purposes are left to be created by the courts. Indeed, in these matters it appears that the courts hearing administrative cases have generated a satisfactory jurisprudence, although an analysis of the judicial role was not available for their study.

No reference is made in the $A P A$ to the principle of proportionality nor to the problem of informal standards being created to guide decision-making, especially in the context of discretion. The only constraints imposed on the decision process are those noted above in relation to notice and hearing, the requirement that the act be issued in writing and should set out the factual and legal grounds on which it is based, and that notification of the act be given to interested parties within three days. This last point on

186 See Administrative Justice Project.

187 Article 10.

188 See Administrative Justice Project. 
notification includes not only parties who have participated in the process, but interested parties who have $\operatorname{not}^{189}$.

An authority may correct its own errors or omissions where these come to its attention ${ }^{190}$. The authority may discover its own errors or omissions, or they might be brought to its notice by the Prosecutor or informally by a party.

\subsection{Giving Reasons}

The decision to issue or to refuse to issue an administrative act must be based on good reasons and the reasons should be stated ${ }^{191}$. Reasons include various matters of routine information, but should include the factual and legal grounds for the decision. They should also include instructions setting out the rights and duties which result from the decision or other act, together with the deadlines for implementation. Where the act meets all the claims of the parties and is in no way controversial amongst them, it is enough to state only the legal basis of the action.

The act or refusal to do an act should be communicated to the parties within three days of its being made $^{192}$. This duty on the authority extends to all interested parties whether or not they took part in the process. Similarly, on appeal, the superior administrative authority hearing the appeal should give a reasoned decision ${ }^{193}$. Questions undoubtedly arise about how comprehensive and detailed reasons must be, especially in relation to the evidence, the facts, and the use of discretion, but it seems that little further guidance on these matters has been given to the courts.

\subsection{Administrative Appeals}

Before the time within which an appeal may be brought, the administrative authority may remedy any defects in the act it has issued. Factual errors of an obvious kind may be corrected even after that time limit ${ }^{194}$. Any corrections so made should be notified to all interested parties. A party may bring any alleged defect to the notice of the authority.

Quite apart from that procedure, an aggrieved party may pursue an appeal before a superior administrative authority ${ }^{195}$. The appeal may be against an act or against the refusal to issue an act. The superior administrative organ, as defined in the $A P A$, refers to that administrative body which is immediately superior to the authority issuing the act at first instance ${ }^{196}$. For example, the administrative acts of local agencies go on appeal to the local mayor, the acts of the mayor go to the district governor, while the acts of a central department go on appeal to the minister. However, no appeal lies within the administration against a significant number of senior officials and authorities. Appeals from the acts of ministers, heads of agencies directly subordinate to the council of ministers, regional governors, and the mayor of Sofia go

$\begin{array}{ll}189 & \text { Article } 17 . \\ 190 & \text { Article } 18 . \\ 191 & \text { Article } 15 . \\ 192 & \text { Article } 17 . \\ 193 & \text { Article } 30 . \\ 194 & \text { Article } 18 . \\ 195 & \text { Article 19. } \\ 196 & \text { Article 27. }\end{array}$


directly to the courts ${ }^{197}$. No appeal either by an interested party or by the Prosecutor lies against the acts of the Council of Ministers ${ }^{198}$. In addition, special laws may provide that administrative acts of any kind should be appealed directly to the courts or to other special appeal bodies ${ }^{199}$. The tendency in recent years is to reduce the range of appeals to special appeal bodies.

Any person or organisation interested in the act may bring an appeal. In deciding the appeal, the superior administrative body shall consider both the legality of the original act as well as the merits ${ }^{200}$. The Prosecutor may also lodge an appeal, but only on issues of law $^{201}$. The application for an appeal must be in writing and should set out the grievances or grounds, together with the remedy sought ${ }^{202}$. The application should also state the evidence on which the appeal is based, although it may indicate that further facts and circumstances ought to be investigated.

The application for appeal is lodged with the administrative body which made the original decision ${ }^{203}$. The application must be made within seven days of notification of the making of the original act or decision, although in some cases an extension may be granted ${ }^{204}$. The original administrative body then considers the application for appeal and it may decide to review its decision and change or modify $\mathrm{it}^{205}$. If it remains unpersuaded, within seven days of receiving the appeal, that its original decision was wrong, the administrative authority shall forward the appeal, together with all relevant documentation, to the competent superior administrative body.

When the administrative body fails to follow this procedure, an interested party may appeal directly to the superior administrative authority. The superior administrative body should make a decision within a strict time frame, and its failure to do so may be challenged by an action before the courts, if the act is one which is questionable in the courts ${ }^{206}$. The appeal body shall consider the matter on its merits, as well as ensure the law is correctly applied, and give a reasoned decision ${ }^{207}$. Procedures for hearing the appeal are not specified in the $A P A$, but the general principle of participation by the parties in Article 11 would apply here.

In normal cases, an administrative act does not take effect until the period for an appeal (7 days) has expired. If an appeal is lodged, then implementation of the act is further suspended until the appeal is $\operatorname{decided}^{208}$. However, exceptions may be made: a specific law or decree may provide for immediate implementation or the administrative authority itself may so order.

Article 20.

198 It should be noted, however, that the actions of the Council of Ministers may be reviewed by the courts for legality: Constitution Article 120.

Article 20.2.

200 Article 21.

$201 \quad$ Article 21.3.

202 Article 24.

203 Article 24.

204 Article 25.

205 Article 26.

206 Article 29.

207 Article 30.

208 Article 23. 
In dealing with an appeal, a superior administrative authority has extensive powers. It may repeal the act in whole or in part for being illegal or incorrect ${ }^{209}$. The superior body may order the original authority to issue an administrative act where the latter has refused to do so. It should be noted, however, that the superior authority cannot itself issue the act where the original authority persistently refuses to do so itself. This may on occasions create an insoluble stalemate. Normally, this situation does not arise and the original authority follows the instructions of the superior authority.

Appeals are normally brought against administrative acts which have not been implemented. There is provision, however, for an appeal against an act which has been implemented ${ }^{210}$. Provided that an appeal has not been made to the courts, the act may be repealed or amended by the superior administrative authority. Where there is no superior administrative authority, as in the case for example of a minister, the authority making the original act may repeal or amend it. This procedure may be initiated by an interested party or by the Prosecutor ${ }^{211}$. In the case of an action brought by the Prosecutor, the act may be repealed or amended only if there has been a serious breach of the law. The procedure assumes that the rights and duties of parties are at stake. Where they are not, the act may be reviewed more readily by the superior administrative body ${ }^{212}$. A major restriction on the procedures for amendment or repeal where the act has been implemented is that the rights of third parties acquired in good faith must not be prejudiced ${ }^{213}$.

The second form of recourse is appeal to the court on issues of legality ${ }^{214}$. Although the Constitution provides for the creation of an administrative court, this has not yet been established. Accordingly, for the time being, appeals go to the civil courts or, in some cases, to special judicial bodies, such as the Military Commission or the Medical Commission. Where special appeal bodies like these are created, the first level of external appeal lies to them on matters of law with the chance to appeal further to the civil courts. Such special bodies may be closely connected to a particular area of administration or to particular administrative authorities, but they are meant to be independent and judicial in nature ${ }^{215}$. This matter is dealt with in the second part of this report and so will be mentioned here only in passing.

An appeal to the court may be brought only after other remedies have been exhausted ${ }^{216}$; this is an important restriction on access to the courts. It seems, however, that an appeal to the court may lie even after the deadline for administrative review has passed. The appeal will be heard either by the district court or the supreme court depending on the relative importance of the original administrative authority. Appeals from the decisions of minister, for example, are heard by the Supreme Court ${ }^{217}$. Strict time limits on bringing an appeal are imposed, although actions seeking to have the original administrative act declared null and void may be brought at any time without limitations ${ }^{218}$. Appeals to the courts may be made by an interested party or by the Prosecutor ${ }^{219}$. The appeal or protest is lodged with the administrative

Article 30.

Article 32.

This procedure is subject to the Code of Civil Procedures, Article 231, 233.

Article 32.2.

Article 32.5 .

Article 33

It was noted earlier, that efforts are being made in the post-communist period to reduce the number and powers of such special jurisdictions.

Article 35.

Article 36.

Article 37.2.

Article 35. 
authority which issued the act in the first place ${ }^{220}$. The administrative body is expected to pass on the documentation to the court within a strict period of time; on its failure to do so, an interested part or the Prosecutor may send the matter directly to the courts ${ }^{221}$. The time limits for bringing an appeal or protest can be extended in any special circumstances ${ }^{222}$.

The duty of the court on appeal or protest is to examine the legality of the action. It should consider whether the act was issued by a competent authority in the correct manner. The court should ensure that the right procedures have been followed and that the substantive law has been properly applied. The court should also be satisfied that the aims and purposes of the law have been respected and followed ${ }^{223}$. Finally, where the matter is not subject to the discretion of the original authority, the court may decide the merits of the case ${ }^{224}$.

\subsection{Conclusions and Matters for Consideration}

Bulgaria has a tradition of administrative law which stretches back to the nineteenth century. Despite the major disruptions of the twentieth century, that tradition was revived in 1970 with the enactment of the Administrative Procedure Act. The commitment to a sound system of administrative law and procedure is manifested in the Constitution of 1991 which reinforces the principles of legality and provides for the creation in the major amendments made to the Administrative Procedure Act in the post-communist period.

There are, however, areas of administrative procedure which need further consideration.

i. The $A P A$ does not deal adequately with the basic principles of notice, disclosure, and hearing. Indeed, the general issue of the disclosure of information by administrative authorities, both in the course of an administrative process and in general, calls for close examination. The openness and transparency of the Bulgarian administration is not yet adequately established.

ii. One of the general characteristics of the Bulgarian $A P A$, as noted above, is the tendency to state procedural principles at such a level of generality and abstraction that it is difficult for officials and authorities to know what precisely is required of them. The result is that often in practice the general principle, while admirable in itself, has little significance in the day-to-day workings of the administration. This points to a need for a more comprehensive and detailed statement of the principles and more detailed guidance as to the meaning and scope of those principles in daily administrative practice.

iii. The range of administrative acts which are excluded from the scope of the APA appears rather wide and without clear justification. The general approach of a code of procedures should be to include all administrative acts, unless there are strong reasons for exclusion. On this point, the APA should be carefully reconsidered.

iv. Like other countries in the region, Bulgaria has relied heavily on the administration supervising itself. Accordingly, the primary form of recourse has been internal administrative appeals. The opening up of the administration to judicial review and the proposed creation of

Article 38 .

Article 39.

Article 37.

Article 41.

Article 42. 
Administrative Courts may shift the emphasis away from internal appeals. But since the courts are confined to issues of legality rather than merits, there is still a great need for some kind of administrative appeal system. Just what form such a system should take and how the present system should be remodelled are matters awaiting serious consideration in Bulgaria.

v. The procedural rules relating to the making of normative acts are now closed and fragmentary. The opportunity should be taken to consider seriously just what procedures should prevail in this increasing important area of administrative law-making.

\section{Estonia}

\subsection{Background to Administrative Law}

Estonia's first Administrative Procedure Act was passed in 1936. This was a general code of procedure which covered all administrative and governmental institutions at both the central and local level. The Act was influenced by the Austrian approach of the time, but it did not place the same emphasis on protecting the rights of citizens as would be expected in a modern administrative procedure code. Nor did it provide for appeal to the court from acts of the administration since that had been established in the Administrative Court Act of 1919.

The Molotov-Ribbentrop pact of August 1939 signalled the end of Estonian independence and provided for Soviet occupation of the country. One year later Estonia was incorporated into the Soviet Union. Nazi Germany invaded in June 1941 and occupied Estonia. This was followed by re-conquest by the Soviet Union in January 1944. The Soviet dominance lasted until the "Singing Revolution" restored Estonian independence in 1992. The Administrative Procedure Act did not operate during this period. Since independence, the Estonian government has been engaged in a vigorous programme of administrative reform and has made efforts to create a suitable legal framework to which the administration must conform and within which the rights of citizens are protected. A general account of the progress that has been made and the plans for the future is given below.

\subsection{The Constitutional Framework}

Estonia gained its independence from Russia for the first time in 1918 and adopted its first Constitution in 1920. The Constitution underwent major damages in the following years until a new version was agreed on in 1938. Estonia remained an independent nation until German occupation during the Second World War, followed by Soviet invasion after the war. The Estonian Constitution of 1938 was repealed during the Soviet period. A new Constitution came into force in 1992 following a referendum of the people. The new Constitution draws on the basic principles of the 1920 and 1938 Constitutions but, with its emphasis on the separation of powers and the protection of the rights of citizens, the new Constitution is more in line with the constitutions of other modern European nations.

The new Constitution contains several articles of importance to administrative law and procedure. In addition to creating a Supreme Court and a system of Administrative Courts, the Constitution provides for the office of Legal Chancellor and sets out the powers of the Executive. It provides for the creation of Ministries of State and the office of State Chancellery; it also requires the setting up of the State Audit Office.

Amongst the more general statements of principle, the following are significant: 
- laws must conform to and administrative institutions must comply with the principles of International $\mathrm{Law}^{225}$;

- $\quad$ the system of law and government is to be based on the separation and balance of powers ${ }^{226}$;

- the Constitution should be interpreted and laws should be made in conformity with the principles of human dignity, social justice, democracy, and the rule of law ${ }^{227}$;

- $\quad$ equality before the law is guaranteed and discrimination on grounds such as nationality, race, language, etc. is forbidden ${ }^{228}$; and

- the organisations of government - legislative, executive and judicial and local government - are charged with the duty of guaranteeing rights and freedoms ${ }^{229}$.

Of more direct relevance to administrative law and procedure are the following articles of the Constitution:

- the law shall protect everyone from the arbitrary exercise of State power ${ }^{230}$;

- $\quad$ everyone whose rights and freedoms are violated has the right of recourse to the courts ${ }^{231}$;

- $\quad$ everyone has the right when his or her case is before a court, to petition for any relevant law to be declared unconstitutional ${ }^{232}$;

- $\quad$ everyone has the right of appeal to a higher court against the judgement in his or her case pursuant to procedures provided by $\operatorname{law}^{233}$;

- $\quad$ Court sessions shall be open to the public ${ }^{234}$;

- $\quad$ each person has a right to obtain information disseminated for public use and all State bodies are under a duty to provide information about their activities on request ${ }^{235}$;

- $\quad$ an Estonian citizen has a right of access to information about himself held by a State authority (subject to some exceptions) $^{236}$;

- $\quad$ everyone has the right to address State authorities with complaints and petitions ${ }^{237}$.

It is interesting to note that in the extensive statement of powers and principles in the Constitution, the principle of judicial review of administrative action is not amongst them. The constitutional basis for the judicial supervision of the legality of administrative action is considered to be implicit in the separation of

\section{$225 \quad$ Article 3.}

226 Article 4.

227 Article 10

228 Article 12.

229 Article 14

230 Article 13.

231 Article 15.

232 Article 15.

233 Article 24.

234 Article 24.

235 Article 44

236 Article 44

237 Article 46. 
powers $^{238}$ and the general right to recourse in Article 15. This is not an entirely satisfactory basis for assessing administrative legality and it is desirable that such an important principle should be given constitutional protection.

\subsection{Overview of Administrative Procedures}

Estonia has not yet enacted a modern Administrative Procedure Act. The need for such a code is widely accepted by lawyers and legislators, and officials in the Ministry of Justice are preparing a draft bill which it is expected will be submitted to the Riigikogu (the parliament) in 1997. The officials preparing the draft are drawing on various sources, but the German and Austrian approaches to administrative law and procedure are especially influential. The current draft, which may well be amended following consultation with other state institutions before submission to the Riigikogu, contains the provisions set out in the next section.

In the interval, until the Administrative Procedure Act is adopted, a range of laws dealing with specific areas and local considerations govern procedures. There is no general or co-ordinated approach, and in many areas there are few formal procedures governing the administrative process with much being left to the administrative authorities themselves. Some laws confer powers on the Council of Ministers or a minister to provide for procedures, but without stating any general principles to be followed in the subordinate legislation. The matter is then left to the discretion of the minister.

\subsection{The Present State of Administrative Procedures}

Since it may be some time before the new Administrative Procedure Act is enacted by the Riigikogu, a brief account of the current position should be given. In the absence of an Administrative Procedure Act during the Soviet period, the procedures of administrative bodies were specific to each area of administrative activity. Since independence, that system has continued with each administrative authority being subject to specific laws and procedures, although in some areas it seems that there simply are no procedural laws. As a result, administrative procedures vary greatly, but it is clear that some of the most basic principles, such as the hearing of interested parties, the disclosure of information, the giving of reasons, and the general openness and transparency of administrative processes are not widely respected.

The primary form of recourse continues to be appeal from the primary decision maker to a superior administrative authority. However, the appeal system rests on a piecemeal and fragmented footing, depending on specific laws rather than general procedural principles. The law and procedures have been reformed in some areas, but, without having detailed information on a wide range of administrative activities, generalisations should be advanced with caution. However, the general impression gained from discussions with officials, judges, and academic lawyers is that administrative officials are not finding it easy to make the transition from an administrative ethos and practice suited to a Soviet bureaucracy, to one based on good quality decision-making, openness and transparency, and general respect for the rights of citizens.

Several of the principles contained in the Constitution and in specific laws may be starting to have an impact on administrative practice. The citizen's right to information, both general and particular, under Article 44 of the Constitution and the creation of Administrative Courts under Article 148 of the Constitution, for the review of the legality of administrative action, are especially significant. In the 
absence of detailed laws for its implementation, however, the right to information may not yet have effective application in practice. While there is no freedom of information legislation, Estonia does have both primary and secondary legislation providing for the protection of state secrets ${ }^{239}$. The absence of freedom of information legislation in Estonia, continued with a tradition of great secrecy in government during the Soviet period, means that adequate information, both in general and in specific administration processes, is often unavailable.

\subsection{The Proposed Administrative Procedure Act}

An unofficial draft of the proposed Administrative Procedure Act has been made available for the purpose of this study. From discussions with officials in the Estonian Ministry of Justice, it appears that the main provisions of the act can be summarised as follows.

There will be a general Code of Procedures for administrative authorities. It will cover, for the most part, administrative acts and decisions of all kinds, whether made at the level of central or local government, with some exceptions of the usual kind. The draft act provides for notice to parties of an impending administrative decision; it gives parties the opportunity to participate in hearings in relation to the making of a decision or the doing of an act; and it makes provision for disclosure to the parties of relevant information about the act or decision. It does not, however, deal with the more general question of freedom of information from government departments outside the context of a particular act or decision by an administrative body. Administrative authorities will be under a duty to give reasons, both as to law and fact, for their decisions. Full provision for a system of internal administration appeals will be included in the act.

\subsection{Subordinate Legislative Acts}

Procedures in relation to the making of subordinate legislation or normative acts are not thought to be a matter of high priority and there is little discussion of the issue in Estonia. There is no general law at present on the procedures for normative acts; nor do particular laws often deal with the matter. In my discussions with officials, however, I was told that the forthcoming legislation on the drafting of laws will include procedural provisions relating to consultation and participation in the making both of parliamentary legislation and subordinate regulations. The details of the proposed law on this matter are not available.

\subsection{Administrative Appeals}

During the Soviet period, the main form of recourse in Estonia for a person dissatisfied with a decision was either to ask the authority to reconsider its decision or to appeal to a higher administrative body. This is very much in line with the position in other countries during their communist periods. Unlike several other countries, however, Estonia did not have a general procedural code governing appeals. Each area of administrative activity had its special rules and procedures, although overall the appeal system was similar to that found in other central and eastern European countries.

In recent years, appeal to the courts from the acts of administrative bodies has been introduced and has become the main form of recourse. A number of reasons can be seen for this reliance on the courts in

239 State Secrets Act (Law No. 45 of 1992). 
preference to internal administrative mechanisms. First, in the post-Soviet period, the Prosecutor's office was deprived of its functions of ensuring the legality of administration. During the soviet period, the Prosecutor exercised extensive supervision over the administration; the tendency was for persons dissatisfied with an administrative act or decision to turn to the Prosecutor rather than to appeal to a superior administrative authority.

Secondly, there appears to be amongst Estonians a deep distrust of the administration, a distrust which probably stems from the harsh and unresponsive nature of the bureaucracy during the Soviet period. In view of this distrust, it is not then surprising that relatively little use is made of appeal procedures which involves one part of the bureaucracy judging another part. Thirdly, as noted earlier, the administrative appeal procedures are fragmented and often unsatisfactory in providing adequate protections of the citizen.

The result of these three factors is that the courts are now considered to be the most reliable and acceptable forum for voicing grievances and seeking redress against the administration. The trouble is, however, that the courts are limited to reviewing administrative actions for legality only and may not examine the substantial merits. Judicial review is not itself an adequate form of supervision of administration.

The new Administrative Procedure Act will propose a general and co-ordinated system of internal appeals, but precisely what form the appeal system should take is a matter of discussion amongst officials in Estonia. One option is to follow the pattern familiar in other countries, so that a person who feels aggrieved by the decision of a primary administrative body, whether agency, department, or minister, will normally have the right to appeal to a superior administrative body. That approach, however, would soon founder on the distrust and lack of confidence Estonians have in the administration.

An alternative would be a middle way between internal administrative review and court review. This could take the form of appeal bodies, which would be knowledgeable about the administration, but at the same time be independent of it. Such appeal bodies should be able to examine the substance and merits of acts and decisions, as well as rule on issues of law. The British system of special administrative tribunals would be one approach worth considering ${ }^{240}$, the Australian system of a general Administrative Appeal Tribunal another ${ }^{21}$. The Estonian authorities ought to give careful consideration to these approaches before finalising the proposed Administrative Procedures Act.

\subsection{Conclusions and Matter for Consideration}

Estonia has begun a period of serious reform in the area of administrative law and procedure. At the heart of the reforms will be the Administrative Procedure Act which now exists in draft form and which should soon begin its passage through the legislative process. This will be a major step forward in bringing the diverse and fragmented administrative processes now prevailing within a general legal framework. How effective and successful the new code will be in achieving these ends will depend vitally on the final form it takes and on how comprehensive it is in its coverage. It is to be hoped that lessons will be learnt not just from the examples of western countries, but also from the valuable experience of other countries in the region. It is also to be hoped that the enactment of the procedural code will not be unduly delayed.

Amongst the matters which should be included in the code, in addition to the usual, more technical procedural issues, the following are especially noteworthy:

For discussion, see W.H.R. Wade, Administrative Law, (7th ed., Oxford, 1995).

241 See Administrative Appeals Tribunal Act (Commonwealth, 1975); for discussion in D.J. Galligan (ed.), Laws of Australia: Administrative Law (Law Book Coy, Australia, 1994). 
i. clear and express principles for notice of proceedings;

ii. proper and adequate disclosure of information, including evidence and documents, to interested parties in administrative hearings;

iii. on the issue of openness and transparency, consideration should now be given to the preparation of suitable freedom of information legislation as a natural and necessary companion to the procedural code. The constitutional provision guaranteeing access to information has paved the way for such legislation; the time may now have arrived for the initiative to supply it to be taken.

iv. clear provision should be made in the code for clear and express duties of authorities to give full and adequate reasons, for their acts and decisions, both as to matters of fact and of law;

v. careful consideration should also be given to the rights of third parties with an interest in an administrative action be notified of and to be involved in it; and

vi. finally, the scope of application of the code should be wide, with the presumption that all administrative actions will be subject to it, unless there are clear and compelling reasons for exclusion.

The other major issue requiring careful consideration concerns the system of appeals for administrative acts and decisions. The creation of administrative courts under Article 148 of the Constitution is part of the solution, but such appeals are confined to legality. There remains a pressing need for a suitable system of lower order appeals on the merits. Estonia is in a good position to look beyond the usual response of creating internal administrative appeals. For the reasons given earlier, the general distrust of the administration as capable of or suited to supervising its own parts may be an incentive for the Estonians to look imaginatively at alternatives. The ideal solution would seem to lie in first instance appeals being brought to special court like bodies which are independent of the administration, while at the same time being knowledgeable about and responsive to it.

More specifically, consideration should be given to the following:

i. whether internal administrative appeals ought to be retained as the primary form of appeal;

ii. if so, what form the appeals should take;

iii. as an alternative, consideration should be given to creating a system of administrative appeals on the merits to an outside and independent appeal body;

iv. the relationship between internal appeals and supervision by the courts and other bodies.

It would now be timely to consider the issue of procedures in relation to normative acts. These are not currently dealt with in any general way under Estonian law; but, as is suggested with respect to other countries, this is an important area of administrative activity which calls for generalised procedures. More specifically, the following two matters should be considered:

i. what procedures should govern the making of normative acts;

ii. whether such procedures should be included in the proposed code of administrative procedure or in a separate general law. 


\section{Albania}

\subsection{The Administrative Law Background}

For five centuries Albania was part of the Turkish Empire. It was subject to Turkish law and had no special status or privileges within the Empire. In 1912, Albania was liberated from Turkish rule and a separate state was established. A monarchical system was created in the early 1920s which lasted until just prior to the Second World War. The communists took power in 1944 and ruled the country until 1992. With the collapse of communism, a multi-party system was created and the first elections were held in 1993. The following years have seen efforts being made to rebuild the economy and to create a system of law and institutions suitable for a plural democratic society.

It has not been easy to form a clear picture of the administrative law background in Albania, but it seems that until very recently there were few signs of a modern administrative law system. Little development took place in the period between liberation from Turkish rule and the communist take-over and, during the communist period, administrative law remained largely undeveloped. Unlike a number of other communist countries, Albania did not adopt an administrative code of general application and the idea that government departments and agencies should be subject to a detailed code of procedure was never seriously entertained. To the extent that there were laws governing the making of administrative decisions and providing for appeal or review of those decisions, the laws were made on a piecemeal basis and in relation to specific subject areas.

In common with other communist countries, the underlying principle was that administrative matters ought to be kept within the administration and that complaints and grievances should be dealt with internally. This idea was particularly powerful in Albania where the looming omnipresence of the Communist Party was the decisive influence on the nature and workings of the administration. This is not to suggest that citizens did not complain or air their grievances; they did, and when they did their complaints were handled internally within the administrative structure and under the eye of party officials.

There may have been limited legal provision for a citizen taking a complaint to a court, during that period, but none of the officials I interviewed in the course of this study could think of an occasion on which this had occurred. In any event, the court system itself was closely aligned with the Communist Party and in no real sense independent of government. The Prosecutor General, as in other communist countries, exercised a general jurisdiction on behalf of the State to ensure that both individuals and institutions complied with the law or, perhaps more accurately, with the interests of the State. One form of administrative scrutiny, therefore, was exercised by the Prosecutor's Office, although it was a form of scrutiny directed to safeguarding the interests of the State rather than the rights of citizens.

In short, when the new system began in 1992, administrative law and procedure, and forms of independent supervision of government and administration, did not exist in Albania in any systematic or adequate sense. In the few years since independence, the importance of a stable and professional public service, operating within a framework of laws and principles and responsive not just to the needs of the State but to the rights and interests of citizens, is now recognised and much work is being done towards its creation.

\subsection{Constitutional Factors}

Albania has not yet adopted a Constitution. A draft prepared in 1993 and submitted to the people voting at a referendum was rejected. There is some likelihood that new attempts will be made to adopt a Constitution in the future, although as this report is being written other matters are of much greater 
urgency. Since the 1993 draft is likely to be the basis of a future constitutional settlement, it is worth noting the provisions in that draft relevant to administrative law and procedure. Principles of a very general nature are:

- the separation of the legislative, executive and judicial powers;

- $\quad$ general principles of international law and principles deriving from treaties should be respected;

- $\quad$ state power is to be exercised according to law and no function or status may be created or abolished except by law; and

- $\quad$ public bodies shall implement the law and the Constitution.

Principles of more direct relevance to administrative law and procedure are as follows:

- $\quad$ each person has the right to be informed by administrative authorities (although it is not clear about what $)^{242}$;

- $\quad$ each person has the right to address any public authority ${ }^{243}$;

- $\quad$ freedom, property, and rights arising under law cannot be abridged without due process of law $^{244}$;

- $\quad$ people have rights to a fair, public, and speedy hearing by a competent, independent, and impartial Court ${ }^{245}$;

- no-one shall be denied the right to seek a remedy against an administrative act which infringes rights ${ }^{246}$;

- $\quad$ anyone deprived of a right recognised by the Constitution shall have a remedy in the Courts $^{247}$; and

- $\quad$ the National Assembly may create specialist courts (including administrative courts) $)^{248}$.

The precise meaning and scope of some of these provisions are not clear, but the draft Constitution would provide a sound basis on which a system of administrative law and procedure could be built.

In the meantime, the National Assembly has passed a number of laws which are known as Constitutional Dispositions. The intention is that one of these, the law on Major Constitutional Provisions (enacted in 1991 and amended since) should provide a constitutional framework until a Constitution is adopted. Amongst the various subjects dealt with in the Constitutional Dispositions are the powers and authority of different political institutions and the courts, the structure and powers of local government, and the protection of human rights.

Article 17.

Article 23.

Article 3.

Article 4.

Article 5.

Article 6.

Article 7. 
A Constitutional Court has been established and is in operation. It takes its authority from the Constitutional Dispositions and is active in developing a constitutional jurisprudence. The jurisdiction of the Constitutional Courts includes the review of acts or decrees by the government and administration to test their constitutionality and their compliance with law. This power extends to general normative acts as well as individualised decisions. The Constitutional Court appears to take its authority from an article in the Constitutional Dispositions on human rights which guarantees the citizen a right to bring a complaint before the Constitutional Court.

In addition to the Constitutional Court, a Court of Cassation has been in operation since 1992 and currently exercises a jurisdiction to review the legality of administrative actions. Under the new Civil Procedure Code (enacted in 1956), a system of local administrative courts, as part of the district courts, will be established and appeals from administrative decisions for legality will go in the first instance to such courts. Appeal on matters of law will lie from District Courts to Appeal Courts and in special cases to the Court of Cassation.

\subsection{Administrative Procedures}

No Administrative Procedure Act has yet been passed in Albania. A small working group, within the Ministry of Justice, is preparing an act for submission to the National Assembly, but it has not been possible to obtain a copy of the current draft. It was difficult, indeed, to gain from interviews with government officials a clear view of how far the draft law has progressed and when it is likely to be submitted to the National Assembly.

However, it is fairly certain that a general Code of Administrative Procedures will eventually be proposed. Without having a draft of the bill available, it is hard to be sure how wide the scope of the Administrative Procedures Act will be or what principles it will include. The intention seems to be to include all acts and decisions of administrative bodies, subject to certain exceptions relating to national security. The notion of an administrative act will include the failure or refusal to act, but it is not clear that it will extend to investigations or enquiries which do not result in a determinative act or decision. Another matter of importance is the need to ensure that the code covers the actions of all executive and administrative bodies (subject to only rare exceptions); the scope of the planned code on this point is not clear.

The code will specify the procedures to be followed by administrative bodies in making decisions or taking action. Provision will be made for the disclosure of information to the parties, hearing parties and witnesses, the giving of reasons, and requiring officials to act in an impartial and unbiased manner. The proposed Conflict of Interest Code for the Albanian Public Service, if adopted, will go some way towards establishing impartiality on the part of administrative officials, but more specific requirements can be expected to be included in the Administrative Procedures Act. The current piecemeal and localised procedures for administrative appeals will be replaced by a co-ordinated system of appeals included in the code. Provision will be made for further appeals on matters of law to the new administrative courts.

The right of appeal to the Courts is now provided for in the recently enacted Civil Procedure Code which will come into operation on 1st June 1996. Provision is made in the Civil Procedure Code for District Courts to form special sections to deal with administrative appeals. Before invoking the jurisdiction of the administrative courts, a party will normally be expected to have first exhausted any available forms of internal administrative review. The earlier discussion of the especially powerful distrust Estonian citizens have of the administration apply equally well to Albania. The Albanian bureaucracy is considered to have been harsh and unresponsive, so that an aggrieved party would be reluctant to complain to it. The courts inspire confidence, but, as in other countries, judicial supervision is still fairly newly introduced and is 
confined to legality. The Albanian authorities should pay close attention to forms of recourse other than internal administrative appeals. The French system of tribunaux administratifs, the British system of special administration tribunals, and the Australian system of a general administration appeal tribunal are all well worth considering.

It may be said with reasonable confidence that the Administrative Procedure Act when it is adopted, will be similar to the codes of other countries across Europe. The code will follow guidelines set by the Council of Europe and will be influenced in a general way by the French and Italian approach to administrative law and procedure. However, the most direct and immediate influence on officials responsible for drafting the code seems to be the Administrative Procedure Code of the Netherlands. It should be said, however, that progress towards concluding a draft code for presentation to the Albanian Parliament is slow, although the reasons for such tardiness are not clear, beyond the fact that other reforms are considered more pressing.

Without detracting from the importance of the work that is being done towards adopting an Administrative Procedure Act, two reservations should be entered. One is that the procedures for making subordinate legislation (normative acts) will not be included in the act and do not appear to be under consideration. The powers of the executive and administration to make subordinate legislation is an important part of administrative activity which often escapes proper legal regulation. Some procedural requirements are imposed by a decision of the Council of Ministers, entitled Functioning Rules of the Council of Ministers (Decision No. 81 dated 6 June 1995) ${ }^{249}$. However, these are not comprehensive.

The other concern is that little progress has been made towards adopting a coherent and satisfactory scheme for obtaining information from administrative institutions. It is not clear, moreover, how far the draft act will deal with this matter, nor is it clear that the importance of adequate disclosure and access to information generally is fully accepted in government and administrative circles. These are two areas of great importance to administrative law and procedure which await further consideration by the Ministry of Justice and other officials.

\subsection{Conclusions}

The state of administrative law in Albania is now undergoing a process of extensive reform. Recent events in the country will undoubtedly be a setback, but it is to be hoped that the process will continue. The first major step should be the enactment of an administrative procedure code, and the comments made above may be of help in ensuring that the code prepares the ground for the development of a modern system of administrative law in Albania.

\section{Comparison and Summary}

It can be seen from this account of administrative procedures that the five countries considered in this study are at different stages in the development of modern systems of administrative procedure. Three of the countries (Bulgaria, Hungary, and Poland) have procedural codes originating in the communist period which have been amended in various ways, but which essentially retain their original form and structure. The other two countries (Albania and Estonia) began the post-communist period without codes of administrative procedures but are now in the process of adopting them. The present state of administrative procedures in these two countries is particularised and unco-ordinated, with each area of administrative

Article 8. 
action having its own procedural rules, or, in some cases, not having rules at all. Officials working on the draft codes in these two countries have available to them the experience of various western European countries, as well as that of their neighbours, and it appears that this is being put to good use.

While this is not the place to offer a detailed assessment of the three existing codes, nor of the drafting projects in progress in the other two countries, a few brief remarks of a comparative and evaluative kind are in order. My remarks will concentrate on the three countries with mature codes, although what is said about them will be relevant to the other two countries.

\subsection{Similarities amongst the Codes of Procedure}

The first observation is that the three existing codes bear a close similarity to each other and have a common structure. To begin with, each deals at length with the scope of application of the code, defining it according to the notion of an administrative act or, in the case of Poland, in terms of administrative decisions. It should be noted in passing that the concept of an action is wider than the concept of a decision. Various exclusions are then made, sometimes based on the area of activity, national security for example, at other times based on the nature or status of the authority, Council of Ministers or the President. It must be said that the basis for some of the exclusions is difficult to understand and to justify.

Since the application of the exclusionary provisions can cause practical difficulties, this is one area in which further thought should be given to developing a simpler and more modern approach. The basis of such an approach would be a procedural code that applies to all kinds of individualised administrative action, including both acts and decisions; the code could then specify the very limited categories of action which are excluded. The strong presumption would be that all action is included, with limited exclusions for actions relating to national defence and security.

\section{2. $\quad$ Neglect of Normative Acts}

A related point here is that a sharp distinction is usually drawn between individualised actions and general normative acts of a legislative kind, with the latter being considered outside the scope of codes of administrative procedure. This is a defensible position to take provided that the procedures governing normative acts are dealt with somewhere else. Some of the countries do have separate laws on the matter, but in general the procedures in relation to normative acts are underdeveloped. This is at a time when, in western jurisdictions, the importance of administrative rule-making, whether under formal authorisation or informally in the exercise of discretion, is coming to be recognised as a major part of administrative activity, raising important procedural issues. Since there is considerable overlap between individualised actions and normative acts, the ideal position would be to include both in the code of administrative procedures.

\section{3. $\quad$ Adequacy of the General Structure of the Codes}

Each of the three mature acts sets out, in varying degrees of detail, the procedures to be followed in the making of an administrative act or decision. These include the kinds of matters one would expect to be found in an administrative code: initiating the proceedings, gathering evidence and information, carrying out investigations and inspections where necessary, examining witnesses, consulting expert opinion, considering the arguments and submissions of the parties involved, forming a decision, and giving reasons both factually and legally for it. These are the vital elements in an administrative process, but the extent to which they are dealt with adequately in the three codes varies greatly, with the Bulgaria's being the most 
sketchy of the three. Judged from the point of view of good quality decision making and effective administration, each of the three codes is a start, but each has areas of concern.

There does appear, however, to be a big gap between the procedures laid down in the Codes and day-to-day administration practice. What happens in practice, is subject to numerous variables and depends not only on the framework of procedures, but also vitally on the quality of the officials making the decisions or carrying out the actions, on the level of resources open to them, on the pressures under which they work, and on the stage of development of a suitable administrative culture. However, to the extent that good quality administration is aided and facilitated by a suitable legal structure, then each of the codes goes some way towards providing that structure. It would be timely, however, for each of the three countries to re-examine their codes in the light of the comments made earlier in this report.

\subsection{Protection of Citizens}

The actions of administrative authorities are to be judged not only according to an objectified notion of good administration, but also according to the relationship between citizens and the administration. We saw earlier that the two are not incompatible, since good quality administration also means that the rights and interests of citizens are respected. In judging how well that latter objective is achieved, various intermediate standards and principles may be employed, each of which in a sense contributes to better quality decision-making while, at the same time, constituting a kind of intermediate test in its own right. I have in mind here, particularly, principles such as openness and transparency, access to information, procedural fairness, the giving of reasons, and the right to appeal from the original decision to an independent authority.

The provision made for access to information varies significantly across the three countries with codes. Hungary and Poland make some, but not adequate provision to ensure that parties involved in administrative actions are able to know what is going on, to obtain information necessary for the proper understanding of the action and in order to present their own case, and to comment on and scrutinise evidence that may be contrary to them. Bulgaria is badly deficient in this regard. Since disclosure and access to information held by administrative authorities is a vital component of transparency, all five countries ought to take a fresh look at the adequacy of their current procedures.

\subsection{Access to Information}

An issue of a more general kind is the need for a law which secures access to information generally. It is important not only that a party be able to be informed of what is going on in the particular case, but also that an administrative authority should be required to disclose various kinds of information about its activities, about the way it decides matters and the criteria it relies upon, and related issues. These are the sorts of matters normally covered in western jurisdictions in freedom of information legislation. Hungary is the only country which, so far, has adopted legislation of this more general kind; the other four countries are at different stages in their discussion of the issue, but in some it is not being taken as seriously as it should be. The enactment of freedom of information legislation is another important step which each country ought to be considering.

\subsection{Exemptions from Disclosure}

A final point to note here is the degree to which information may be withheld either generally or in the course of an administrative process, for various reasons, usually but not always associated with defence 
and national security. The risk here is that the categories of exclusion are left open-ended and subject to broad interpretation when applied in practice. Whilst secrecy is the natural refuge of government, every effort should be made to ensure that information is withheld only on matters which are of vital necessity to the security of the State. Several of the countries have worked on this issue with a view to reaching acceptable definitions of state security, but in general it is an important and sensitive matter which needs close consideration.

\subsection{Openness and Transparency}

The openness and transparency of administrative processes can be judged according to various criteria: access to information, involvement and participation of the parties in the process, public hearings (where appropriate) and the giving of reasons. Each of the three codes deals with these matters in varying ways, as seen in the preceding chapters. In addition to the provisions regarding access of information noted above, the parties are given notice of the proposed proceedings and are entitled to participate in it through being present at the examination of witnesses, by having access to the files during the course of the process, and by being able to make arguments and submissions to the authority. Each code requires that reasons both of fact and law be given for acts and decisions.

\subsection{Due Process and Fair Procedures}

Procedural fairness or due process is another intermediate principle which casts light on the relationship between the citizen and administrative authorities. The first requirement of procedural fairness is that there be procedures which lead to a proper and accurate application of legal standards or, where appropriate, that discretion be exercised according to the right considerations. In order to ensure proper and accurate decision making in this sense, it is necessary that the parties have access to information, that they be able to participate in the process through submission of evidence and oral hearings where appropriate, that the decision maker be impartial and unbiased, and that a reasoned decision be given. Again the codes meet each of these requirements to varying degrees.

Procedural fairness may occasionally go beyond this instrumental sense of procedures to invoke values which are important in themselves. It is often said, for example, that hearing a person is an important element of procedural fairness irrespective of whether it contributes to a more accurate outcome. We need not enter into a discussion of the relationship between the instrumental and non-instrumental sense of procedural fairness, since the so-called non-instrumental values such as being heard, having an impartial decision-maker, and being given reasons are all satisfied by the codes.

\subsection{Regulating Administrative Discretion}

One matter which is not dealt with in the codes, but which I have commented on in dealing with each country, concerns various principles which influence and constrain the decision-making process. These principles may be of a more procedural nature, such as the principle that an authority should not fetter its discretion or abdicate its responsibility to another body. They might also be of a more substantive kind such as the principles which require that, in the exercise of a discretion, only relevant matters be taken into account and irrelevant matters be avoided. Another example is that an authority should act reasonably, or at least in a way which is not grossly unreasonable. As noted before, one aspect of unreasonableness is the doctrine of proportionality which is coming to be an important principle in the legal systems of Western Europe. 
These matters are not dealt with in the codes although they are clearly of great relevance since they constitute principles governing administrative processes. It is not unnatural in western jurisdictions for these principles to be developed over time by the courts exercising review, rather than to be inserted in procedural codes. It may be that, with better procedures for judicial review of administrative action in each of the five countries, the courts will develop these doctrines which will, in turn, be respected by administrative authorities. That has already happened to a significant degree in the two countries (Hungary and Poland) which have a reasonably well-established tradition of judicial supervision of administrative action. My interviews with judges and lawyers in the other three countries suggest that they will be keen to develop similar principles, as judicial review by the courts becomes better established. There is, however, still a strong case for such principles being incorporated in a procedural code.

\subsection{Forms of Recourse}

The final point to comment on concerns the appeals structure. A striking feature of the three codes is the emphasis on grievances and complaints about primary decisions being dealt with by a superior administrative body, rather than by an external and independent authority. This may be a reflection of a view of the role of administration under communist systems, but to the outsider such an approach seems to be somewhat inward-looking. The question should be asked whether such emphasis on internal administrative appeals should be the main form of appeal in a modern administrative system. There are obvious difficulties with internal appeals, examples being the inclination to secrecy, and the close relationship between the primary decision-maker and the appeal body. These problems can be overcome, but in order to do so it is necessary to have both clear procedures and carefully constructed forms of quality control.

The advantages of internal appeals are mainly that they are informal and inexpensive, and they often mean that the appeal body has special and detailed knowledge of the area of activity in which the appeal is brought. The challenge is how to capitalise on the strengths of internal appeals while at the same time neutralising the negative factors ${ }^{250}$.

The emphasis in western jurisdictions is to ensure that an aggrieved party has the opportunity of taking the appeal beyond the administration itself to an independent judicial-like court or tribunal. It is thought to be important that there be one external appeal which allows not just the legal issues, but also the merits of the decision, to be re-examined. On the contrary, the tendency in the countries studied here is for the primary appeal to be internal to the administration, with recourse to the courts only on matters of law (although it should be noted that in several countries there are a number of court-like authorities to which an appeal lies on the merits).

The general point to be noted is that a more comprehensive view of the appeal procedures needs to be taken in the countries in question and more careful consideration given to the best structure to ensure both good quality decision making and respect for rights and interests.

One noticeable feature, which is most evident in Albania and Estonia, but also present in the other three countries, is a distrust of the administration. That has led to a deep-seated scepticism about the usefulness of appealing from one administrative body to another. The results of this is likely to be that persons dissatisfied with an administrative action will seek forms of recourse other than internal administrative appeals. The courts are likely to be seen as more reliable and, therefore, may become the main focus of 
complaints. Where ombudsman have been created (Hungary and Poland), they may also be seen as providing a form of recourse preferable to internal administrative appeals ${ }^{251}$.

The conclusion to be drawn for present purposes is that the internal administrative appeal system, which is common in varying degrees to all five countries, needs to be reconsidered. It is important that there should be some form of appeal on the merits of a decision, as much as its legality. The most suitable form such appeals should take, however, is a matter to which each of the five countries ought to give serious thought $^{252}$.

251 This seems to be borne out in Hungary where, in its first year of operation, the Commission for Civil Rights was inundated with complaints: see Part II of this report.

252 Awareness of this issue is especially noticeable in Estonia where the appeal structure is under review. 


\title{
PART II: JUDICIAL AND NON-JUDICIAL SUPERVISION OF ADMINISTRATIVE PROCESSES
}

\author{
A. FORMS AND OBJECTIVES OF SUPERVISION
}

\section{Introduction}

\subsection{Objective of Part II}

In Part I of this report, the task was to give a description and analysis of administrative procedures in the five countries examined. The focus there was on the procedures governing administrative processes, and on the way that administrative authorities exercise their powers. The main object of that part was to examine the legal framework within which the administration of each country operates and to obtain an idea of how it operates in practice. On the basis of that analysis, a critical and comparative assessment was made of the different legal structures in the five countries, with special reference to the administration procedures of each.

This second part of the report begins in a sense where the other finishes, for the object here is to examine the various institutions and procedures of supervision and oversight of administrative processes. These include the forms of recourse open to a person who feels aggrieved by the acts or decisions, or indeed by the failure to act or decide, on the part of an administrative body. Accordingly, the various mechanisms of appeal, review, or other ways of dealing with complaints will be examined. The common characteristic of these mechanisms is that they are usually invoked by an individual party seeking recourse; they cover courts, special tribunals or other court-like bodies, and ombudsmen in their many different guises.

It is important here to note that this report deals only with supervisory institutions which are external to the administration. As noted in Part I, an idea common to central and eastern European countries is that the administration should supervise itself. This idea had special appeal during the communist period, but it is not exclusive to that period and can be seen in various forms in earlier periods. It did have the consequence, however, that under communism there was little scope for external supervision, whether judicial or non-judicial, of the administration. Some countries began to allow limited judicial scrutiny towards the end of the communist period, but internal control and supervision remained dominant.

In the years since the end of communism most countries in the region have been active in creating new institutions and mechanisms of supervision which are external to and largely independent of the administration. But while the emphasis has moved away from internal forms of supervision to external, the former have still been retained rather than abandoned, so that the two exist side by side. This can create a certain tension between the two, as will be seen at several points in this report; it can also make the appeal process rather complicated. Since internal appeals are examined in Part I, they are not dealt 
with here, except in passing. The object here is to identify, examine, and compare the external forms and institutions of supervision of the administration.

While this report pays particular attention to the more individualised forms of supervision, such as courts and ombudsmen, these do not cover the entire range of external supervisory mechanisms. Accordingly, this study includes other forms of supervision which do not necessarily depend on a complaint being made by an individual or group, but which are of a general and continuing kind. Several types of inspectorates, boards, and commissions fall within this category. The feature common to each is usually a general statutory duty to scrutinise the actions of certain primary administrative bodies to ensure that they comply with specified standards.

The audit commission, which has a general supervisory role in relation to financial matters, is one example, while inspectors of schools, prisons, and hospitals are other examples. In some countries, the prosecutor or procurator, whose main functions are in relation to criminal law, also has a role in questioning the legality of administrative acts and decisions. Another kind of oversight may be exerted by the parliament itself, partly through questions and debate in the chamber and partly through the creation of special committees, each with powers of scrutiny and supervision of particular areas of administration.

The countries considered in this report vary greatly in the extent to which they have developed these different mechanisms and, as the following pages show, in some countries very little exists at all. It is important, however, to have as full a picture as possible of the kinds of supervision which may be employed to make the administration accountable, transparent, and responsive. I would suggest, indeed, that it is possible and helpful, by drawing on the experiences of a number of countries, both western and eastern, to sketch a comprehensive and coherent plan of the forms and methods of supervision which are desirable in a modern democratic society. That is not my object in this report, although the analysis here should be a sound foundation for such a plan.

The structure of this report is as follows. First, a brief description is given of the different kinds of supervisory institutions and mechanisms, with particular attention being paid to the distinctive functions of each. Secondly, a link is made between the forms of supervision and underlying goals and values, in particular, good quality administration, the rule of law, fairness and respect for rights, and openness and transparency. Thirdly, an analysis is offered of the supervisory mechanisms in each of the five subject countries - Hungary, Poland, Bulgaria, Estonia and Albania. Fourthly, a critical and comparative study is made of the five countries.

A final preliminary point to note is that it has not been possible for the purposes of this report to conduct a comprehensive study of the different kinds of supervisory bodies. Each country has a considerable range of special boards, commissions, and inspectorates, all of which have a role in supervising different parts of the administration. A full analysis of such bodies for each of the five countries would require a substantial commitment of time and resources which was not available for the present study. A full study of the many different supervisory bodies for each country of the region would be of great value.

\subsection{A Note on Terminology}

It may be useful at the very beginning to offer a few words of explanation of the terms used in this report. Courts, tribunals, ombudsmen, prosecutor, etc., are all terms which at first sight appear familiar and uncontentious. And yet, as any comparativist must learn at the very first lesson, initial familiarity may lull us into thinking that the term has the same meaning and significance from one legal system to another. The truth may be that beneath the surface, similar terms signify very different concepts, concepts which 
themselves can be fully understood only in their own legal and social setting. To be aware of the problem is not to be daunted by it, for if any comparative work is to be done, some common ground must be established as to the meaning of the terms used and the nature of the concepts conveyed. In order to mark-out some common ground, the following brief notes may be helpful.

Courts. Courts vary greatly in their composition, powers, and mode of operation, but the crucial factor is that they be judicial bodies, the primary function of which is to adjudicate upon issues between parties by the application of legal standards. To be a judicial body, a court must be staffed by judges who are independent of government and administration, and of the parties to disputes before the court. The judges should have legal qualifications; they should also have extensive experience in legal practice and some reasonable level of training in judging. Within this broad definition, courts may vary greatly in the range of their powers and the scope of their authority.

Judicial Review. Judicial review is used to refer to the process by which courts exercise a supervisory power with respect to the administration. The essence of judicial review is that, in response to an application by a person or group of persons, the court examines an action performed by an administrative or executive authority to determine whether it complies with the prevailing legal standards. Judicial review is usually confined to determining the legality of administrative actions, but its precise scope may vary. In some areas of administration the courts may have the authority to go beyond the principle of legality and to examine the merits and factual basis of the action, although judicial review of the merits of an action is rare.

In some western jurisdictions, judicial review has a narrower and more technical meaning than that above, but in this report the term is used in its widest sense. It should be taken to include any form of supervision which the courts, whether special administrative courts or the ordinary civil courts, exert over administrative bodies. Judicial review includes appeals to the courts and, in the use of the term here, no distinction is intended to be drawn between appeal and review.

Principle of Legality. While a whole treatise could be written on the principle of legality, it here means essentially that administrative activity is conducted within a framework of legal standards. That in turn means that: (i) administrative bodies derive their powers from legal sources and have only such powers as are so conferred; (ii) any action which is not authorised by law is unjustifiable and of no legal effect; (iii) on the exercise of its power, an administrative authority acts in accordance with such standards as are laid down by law, whether in the Constitution or in general or particular statutes, or by the courts in the exercise of judicial review. Indeed, it is usual for the courts to create principles of review which are not stated in any political legal enactment, but which are extensions and extrapolations of the general idea of legality.

Ombudsman. The term ombudsman refers to authorities which investigate complaints made by persons about the actions of administrative authorities. Ombudsmen are usually independent authorities created under law by the legislature and given specific areas of jurisdiction. They usually report annually to the parliament or national assembly. "Ombudsman" is a generic term which refers to a range of institutions; indeed, it is not often used in practice in legal terminology, where the terms "parliamentary commissioner" or "commissioner" appear more frequently.

Prosecutor. The term prosecutor is one that is especially prone to cause confusion when used loosely. In many countries of continental Europe, especially those of Central Europe, the prosecutor occupies a central role as a guardian of legality in administration. The prosecutor's office is usually created under law and, in addition to its role in bringing criminal prosecutions, has a public law side. It often may investigate allegations of administrative illegality, and propose correction; it may initiate proceedings in 
the courts; or it may join in proceedings brought by another party. The prosecutor occupied a very central place during the communist period and was often associated closely with the ruling political party. Confusion about the nature of the prosecutor is likely to arise because, in the Anglo-American tradition, its role is confined to matters of criminal prosecution and it has no public law function. In some countries, those are public officials or officers which perform a public law function similar to that of the prosecutor as described. An example is the Commissaire du Governement in France, the Attorney General in England, and the Prosecutor Fiscal in Scotland.

Each of these ideas and institutions will be explained more fully in the following pages.

\section{Forms and Institutions of Supervision}

In discussing the different forms of supervision of administration, the following order is adopted: judicial review, prosecutor, appeal on the merits, ombudsmen, internal complaints procedures, inspectorates and similar institutions, and finally parliament and the committees of parliament. Whether there is a best order in which to consider the list is bound to be a matter of opinion. Some might prefer to take a different view and treat the forms of supervision in the order of heaviest use, or perhaps according to the degree of their likely impact on the administration ${ }^{253}$. In the absence of any obvious or compelling order, I have chosen to take judicial supervision first, not because it has the most impact on the administration or because it is heavily used, but simply because a sound system of judicial review is a fundamental requirement of constitutionalism and the rule of law.

Whatever other mechanisms and institutions may be desirable, in countries which have recently moved from a regime of bureaucratic administration where the objectives of the ruling political party were paramount, to one where the administration is conducted within a constitutional and legal framework, supervision of the administrative process by the courts is essential. Judicial supervision is a cornerstone of constitutionalism and the rule of law; it may be built on and added to, but it is not itself optional. For that reason it is important that it should head the queue of supervisory devices.

\subsection{Judicial Appeal and Review}

\subsubsection{Nature of Judicial Review}

The form of supervision of administration which is at the heart of a society based on the rule of law is judicial review. By judicial review, I mean the process by which an independent court examines an administrative action to determine whether it complies with the principle of legality. By the principle of legality is meant the legal rules and principles, deriving from the constitution, statutory enactment, or judicial decisions, which govern administration in general and specific areas of administration in particular. Judicial review is normally triggered by a party, who is affected by the administrative action, commencing proceedings, although provision is often made for a special public authority, such as the Prosecutor, to take the initiative.

Whether the proceedings are referred to as judicial appeal or review or some other variation does not matter, provided that they retain their essential character as the scrutiny of legality. Nor does it matter

253 It ought to be noted, however, that impact is a difficult thing to measure and that little is known about the respective impact of different forms of supervision: see further D. J. Galligan, Due Process and Fair Procedure (Clarendon, Oxford 1996). 
whether review is exercised by special administrative courts, as in France and Poland, or by the ordinary superior courts, as in the United Kingdom and Hungary. The mutual historical contempt of the French and the British for each other's system was based on a misunderstanding about what is important: for the crucial factor is not whether the reviewing court is classified as part of the administrative arm or not, but whether it is a genuinely independent of government and administration in the performance of its functions. The records of the French Conseil d'Etat and the English High Court show that, despite marked differences in character and structure, both clearly are operating at a high level of independence and detachment from the administration.

\subsubsection{Judicial Review and Legality}

The principle on which judicial review is based is that administration should be conducted within a framework of laws, and that it is for the courts not the administration to have the final decision as to whether, in a particular case, that is so. The laws governing administrative action may be grouped broadly into three kinds: laws defining the powers of an administrative body in any context, often referred to as the jurisdictional standard; laws imposing standards on the manner in which administrative bodies make decisions; and laws prescribing the procedures to be followed.

The assumption behind the first is that any administrative authority has only the powers conferred on it by law and that any actions which are not authorised by law are by definition outside the law and of no legal effect. By law here is meant the particular statute or act of the parliament or national assembly or other law-making body which confers powers on an administrative authority. Such laws confer powers across a great spectrum of matters including social welfare, taxation, licensing in its many forms, and the conferring of state benefits of various kinds; it also includes substantive laws regulating a host of activities where an administrative authority is created to oversee and enforce the regulation.

To this basic principle that any administrative body has only those powers conferred by substantive laws, should be added a subsidiary principle that the scope of the powers of administrative bodies ought to be defined with reasonable clarity and specificity, and that the criteria upon which they are to be exercised should be reasonably precise. The corollary is that the notion of an authority having inherent powers, or its being granted wide discretionary powers, is to be frowned upon. We need not here enter into the debate about how much discretion should be conferred on administrative bodies, except to note that some discretion is necessary, even desirable, in modern administration, and yet at the same time that efforts should be made to keep discretion confined as strictly as possible ${ }^{254}$.

The second group of laws within the principle of legality is directed at the decision process itself, imposing standards such as good faith, rationality, reasonableness and proportionality, equal treatment and non-discrimination. Such standards may originate in the constitution or from international treaties like the European Convention on Human Rights; alternatively, they may originate in the decisions of the courts and evolve over a long period into general principles. Whatever their origins, such standards become part of the legal framework within which administrative bodies must work, and their violation becomes a basis for judicial review. The third category of legal standards constituting the principle of legality is procedural in nature. Within the general concept of procedural due process or procedural fairness, more detailed procedural rules are generated. Examples are the hearing principle, which includes notice and disclosure as essential elements, the rule against bias, and the giving of reasons. The significance of these principles is that, once established as binding legal standards, any breach may invalidate the whole process.

254 For full discussion of these issues, see D.J. Galligan, Discretionary Powers (Clarendon, Oxford, 1986). 
It can be seen from this brief account that, while certain general standards are necessary to give meaning and substance to the principle of legality, considerable scope remains for marginal variations within the principle. Like any abstract principle, the notion of legality can be given a wide or narrow interpretation, and since its precise scope depends on the judgements of national (and to a lesser degree international) courts, it is not surprising that the details vary from one jurisdiction to another. This can be seen in the practice of judicial review across the major jurisdictions of Western Europe - Britain, France and Germany - where there is general agreement about general principles, but significant variation at the level of detailed grounds of review. One consequence of European law, and of the active role of the European Court of Justice in developing administrative law principles, may be that a stronger sense of a common European law of judicial review and the principle of legality will gradually emerge.

\subsubsection{Importance of Judicial Review}

Moving now from the grounds of review and the principle of legality to the importance of judicial review, it should be repeated that the provision of judicial review of administrative action is a fundamental requirement of a society based on the rule of law and constitutional principles. The provision of judicial review of administrative action signifies a commitment to the idea that the government and administration must act within the scope of legal authority. The ability of an aggrieved party to have the legality of administrative actions tested in the courts signifies a particular kind of relationship between the citizen and the state, a relationship within which administrative powers are limited and the rights of persons are respected.

Without doubting the importance of judicial review of administrative actions, it should be recognised, however, that it is only a limited form of recourse. One limitation is inherent in its very nature, because, being limited to legality, judicial review does not typically enter into the merits of administrative action. Another limitation is that actions for judicial review are likely to be brought in only a tiny fraction of the cases in which a party subject to administrative action feels aggrieved. While millions of decisions affecting people are made each year across the spectrum of administration, we know from empirical research in the United Kingdom that the number of actions for judicial review is in the hundreds ${ }^{255}$. Amongst those hundreds, moreover, it has been found that a high percentage relate to two specific areas of administration where inadequate provision is made for other forms of recourse ${ }^{256}$. I do not know of similar research in other European countries, but it may be assumed that the position is similar, with recourse to the courts from administrative action being a special procedure used sparingly.

The reasons for this are clear enough. One is the cost of bringing an action for judicial review. In the United Kingdom, where the procedure is adversarial and the party must bear the responsibility of initiating and conducting the action, the costs are substantial. That in itself is a severe deterrent to an aggrieved party bringing an action. In other European countries, of which France is the most notable case, where responsibility for conducting the action, once it has been initiated, lies with the court and its officials, the problem is not cost but delay. Before the French administrative courts it is not unusual for an action for

review to take several years ${ }^{257}$. The investigative process, when left to the court itself, is thorough but inevitably very slow.

255 See M. Sunkin, L. Bridges, and L. Mazeros, Judicial Review in Perspective (1993, Public Law Project, London).

256 In the United Kingdom, the two areas in which judicial review is most often sought are immigration and the provision of public housing.

257 See J. Bell and J. Neville Brown, French Administrative Law (Clarendon, Oxford, 4th ed., 1993). 
Perhaps an even more significant problem is simply the lack of awareness amongst those subject to administrative action of the possibilities of judicial remedies. And where there is such awareness, the difficulties as perceived by the party of even commencing an action may be an effective deterrent. Research has shown that whatever the efforts to make procedures simple, clear and informal, the great majority of parties will still find them forbidding, especially in the absence of legal or specialist advice ${ }^{258}$.

However, to point out the limitations of judicial review as a form of supervision of administration is not to deny its fundamental importance. It is important for two main reasons. The first is that referred to above: judicial review is the ultimate mechanism for determining whether administrative authorities use their powers according to law. It is, therefore, of clear importance in safeguarding the rule of law and in protecting the rights of parties. Secondly, judicial review has a significance beyond the particular case, for it is concerned not just with deciding the legality of an act or decision in that case, but also with formulating and declaring general principles of administrative law and procedure.

In all western jurisdictions, including that of the European Union, the courts have played a major role in developing a set of general legal standards governing the conduct of administration. Those standards, referred to in more detail above, sometimes have their origins in constitutions and international treaties, but even then it is the courts in exercising judicial review which breathe life into them. This applies not only to the English superior courts and the French Conseil d'Etat, the two most notable examples, but to all national courts across Europe. In short, judicial review, while triggered into action by a particular case, is a forum for the creation and refinement of legal principles of general application to the administration.

The stipulation of principles by the courts in exercising judicial review does not of course guarantee that they are followed by administrative officials and agencies. Indeed, some empirical support exists for the suggestion that the influence in general is low. One reason for this is the ignorance of such principles on the part of officials. Even if officials know of the legal principles, they may work under such pressures of time and scarce resources that the principles are lost in the day-to-day bustle. A second reason for the marginal influence of judicial review may be that the legal principles are simply displaced by other informal rules and standards which prevail within an organisation ${ }^{259}$.

\subsubsection{Courts Responsible for Supervision}

A brief word should be said about the system of courts in each of the countries studied and the responsibility of different courts for supervising the administration. The general pattern in these countries, as well as in the region more generally, is for judicial supervision to be the responsibility either of the ordinary civil courts or of special administrative courts. Three of the countries (Estonia, Hungary and Albania) have decided against the creation of special administrative courts, preferring judicial supervision of the administration to be left to the ordinary civil courts. Within that system, it is usual to create a special administrative division, not as a separate court system, but as a specialised section of the civil courts. Poland and Bulgaria have both revived earlier traditions of administrative courts and, accordingly, have made provision in their respective constitutions for such institutions. The Polish Supreme Administrative Court is now functioning, but so far the Bulgarian constitutional provision has not been put into practice. Within the court system of each country, whether the ordinary civil courts or special

258 H. and Y. Genn, The Effectiveness of Representation before Tribunals (Lord Chancellor's Department, London, 1989).

259 See further I. Loveland, Housing Homeless Persons (Oxford, 1995) and J. Baldwin, H. Wikeley and R. Young, Judging Social Security (Oxford, 1992). 
administrative courts, there is usually first instance review followed by the possibility of appeal to a superior division.

The constitutional courts in each of these countries vary greatly in their powers and duties from one country to another, but they do not normally become directly involved in supervision of the administration. There may be indirect involvement in that the constitutional court may have to give a final interpretation of sections of the constitution dealing with the principle of legality and review of administrative action.

\subsection{The Role of the Prosecutor}

Although we naturally identify the office of the prosecutor with the bringing of criminal prosecutions, in Central and Eastern Europe, the same office often has a limited but important function in relation to the administration. The gist of that function is to initiate proceedings before the courts to test the legality of an administrative action where the prosecutor has grounds for thinking that it may be illegal. The prosecutor retains this function in several of the countries examined in this report. While it may seem unusual to the outside observer that this administrative law function should be vested in an office primarily concerned with the criminal law, it is not at all unusual for the office itself to exist. All western jurisdictions with which I am familiar have an officer whose functions include taking action in the public interest against administrative bodies which are acting or have acted in breach of the law.

The idea behind the office, however it might be designated, is admirable. It is clearly desirable to have a public official who may bring judicial proceedings to force administrative authorities to stay within their powers and to act according to law. There is clearly a public interest in ensuring that government and administration act legally and there may be occasions, sometimes celebrated occasions, where no private party with sufficient interest is able or willing to bring proceedings in the courts. The main reservation to be entered is not about the principle of the office, but the practice. I have not been able to find any systematic and comparative study of the office, but the general impression gained from my own knowledge of several jurisdictions in the region, and from enquiries about others, is that, in the post-communist period, the powers of the prosecutor are exercised neither frequently nor regularly.

In Central and Eastern Europe, the office of the prosecutor assumed considerable importance during the communist period. The Prosecutor's public law functions were often extensive and tended to be closely associated with the executive and the Party. Practice varied across the region, but in some countries, including the Soviet Union, the Prosecutor was feared and distrusted; the office was seen as concerned less with upholding the legality of administrative action and more with ensuring that the wishes of the executive and the senior officials of the Communist Party were properly executed. The result has been that in those countries which had particularly bad experiences of the repressive role of the Prosecutor, Albania and Estonia for instance, the office has been abolished or stripped of its public law functions.

In other countries, the office has been retained and sometimes given constitutional legitimacy; but invariably its powers have been reduced and its general importance has diminished. The Hungarian Constitution, for instance, states that the prosecutor's function is to ensure that the law is observed by all social organisations, state bodies, and citizens ${ }^{260}$. Similar provisions are made in other countries of the region. The reality, however, is that the office has lost a great deal of its importance. This is partly 
deliberate and partly the consequence of the creation of other forms of supervision of the administration, especially judicial review, ombudsmen, and special inspectorates.

\subsection{Appeal or Review on the Merits}

\subsubsection{The General Idea}

In earlier discussion, the focus was on judicial supervision to ensure compliance with legal principles. That does not, however, exhaust the possible scope of judicial supervision. The courts may also be deployed to provide an appeal or review on the substantive merits of administrative actions. The distinction between the two concepts is important: the object in the first is to determine whether the authority has acted within the scope of its legal authority and has complied with relevant legal rules and principles; the object in the second is to examine the evidence, the facts, and the judgement about those facts in order to determine whether the decision made or action taken is the best or most supportable in the circumstances. The line between the two processes is not always easy to draw either in principle or in practice; legality is a malleable notion in principle and, in some of its aspects, may seem in practice to involve the court unavoidably in matters of merits and substance. Despite these difficulties, which are at the very heart of administrative law and which need not now be examined, the distinction between legality and merits is of vital importance, with the judicial scrutiny of administrative action usually being confined to the former.

However, it is recognised in many jurisdictions that the courts, or special court-like bodies, should play a significant role in scrutinising the merits and substance of administrative actions. The French Tribunaux Administratifs have power to examine the merits of administrative actions in certain contexts ${ }^{261}$, while the British system of special appeal tribunals is very much directed to providing an appeal on the merits from administrative decisions ${ }^{262}$. The most striking example of all is the Australian system of Administrative Appeals Tribunals under which a set of general tribunals has been created to consider appeals from administrative actions ${ }^{263}$. The tribunals usually include members with knowledge and experience of the areas of review; they are, however, distinctly judicial in nature. The tribunal has wide powers not just to examine the decision of the primary authority to decide whether it is wrong in some respect; the tribunal is required positively to consider the matter afresh and to substitute the decision it thinks best, even if no error can be found in the original decision. Where discretion has been conferred on the primary decision-maker, the appeal tribunal is required to consider and re-exercise the discretion as it thinks fit.

From these examples, we can see the different kinds of appeals that may be created and how exacting they may be. Different jurisdictions develop different structures, some creating special tribunals or courts, others relying on the existing court system. Some jurisdictions combine both powers of review for legality and review on the merits in the same court, while others keep the two separate, usually vesting the higher courts with questions of legality and lower courts or special court-like bodies with review on the merits. Where appeal bodies such as tribunals are specially created, they may take the form of a general tribunals, as in the Australian case, or they may specialise in the sense that each area of administrative decision making has its own appeal tribunal, as in the United Kingdom.

261 See Bell and Brown, French Administrative Law (Clarendon, Oxford, 4th Ed., 1995).

262 On the tribunal system, see H.W.R. Wade, Administrative Law (Clarendon, Oxford, 5th ed. 1992).

263 For an account of the Australian system, see D. J. Galligan, "Tribunals" in D.J. Galligan (ed.), Laws of Australia: Administrative Law (Law Book Company, Sydney, 1993). 


\subsubsection{The Approach in Central and Eastern Europe}

The dominant approach in the countries of Central and Eastern Europe during the communist period was to keep appeals strictly within the administration and executive, with no or at most minimal outside scrutiny. This approach, which still greatly influencing, if not dominating, the administrative law system of the region, usually consists in appeals being made against the actions of one administrative authority to a superior ${ }^{264}$. In some countries, of which Hungary and Poland are good examples, the administration was opened up during the communist period to very limited outside scrutiny by the courts. That process increased substantially in the democratic period, so that now judicial review by the courts for legality runs parallel to systems of appeal internal to the administration. This is not entirely satisfactory, but judicial review can be sought, normally, only after internal appeals have been exhausted; in any event, judicial review is usually confined to the legality of the action rather than its merits.

\subsubsection{Relationship between Internal and External Appeals}

One question to consider is the relationship between external and internal appeal procedures. The countries of Central and Eastern Europe have relied heavily on internal appeal procedures, generally to the neglect of external mechanisms ${ }^{265}$. The usual pattern in these countries is for an appeal on the merits to lie from the primary decision-maker to a higher administrative body. That tends to be the only form of appeal on the merits, with any external recourse being confined to issues of legality before the courts.

Western jurisdictions, on the other hand, vary in their practices, but if there is a typical model it combines elements of internal and external appeal. A familiar approach is for the department or agency to create an internal system of appeal, sometimes as a matter of statutory duty, at other times at its own initiative. The internal mechanisms tend to be very informal, with the barest complaint from a party being enough to set them into motion. Once set in motion, officials within the administrative organisation will investigate the complaint to see whether it has merit. This may be done by a senior official or special body of officials; sometimes it may begin with a review by the very official who made the original decision. The internal procedures are often then supplemented by the right to appeal to an external body, normally a court or tribunal.

It would appear, at least in the United Kingdom, where external appeals to tribunals or special courts have long been established, that greater efforts are now being made to develop and improve internal procedures as the first port of call. The trend in this country is to allow recourse to external procedures only after the internal have been exhausted.

The combination of internal and external appeal procedures appears to be an attractive model for any country reforming its system. Internal procedures have the advantage of being informal, easily accessible, and economical (for both the parties and the administrative authority). Many of the most elementary errors can be corrected simply and speedily at this stage without need for further recourse. At the same time, internal procedures have their short-comings: the quality of decision-making may be low; there may be very little real distance between the original decision-maker and the official deciding the appeal; and the process is likely to be conducted in the relative secrecy of the department with little regard for openness or disclosure. There may also be long delays.

264 This issue is discussed more fully in Part I of this report.

265 See Part I of this report. 
Now of course efforts can be made to overcome these problems and useful lessons can be learnt from jurisdictions which are trying to improve the quality of internal appeal procedures ${ }^{266}$. Internal mechanisms can be put on a sufficiently formal footing to overcome the natural community of interest amongst administrative officials within the same organisation. Through a number of simple devices, the process can be made more transparent, and the quality of the appeals can be improved not only by better and more focused training of the officials, but also by carefully devised methods of outside supervision.

\subsubsection{The Case for External Appeal on the Merits}

However good the internal mechanisms of appeal may be, it is arguable that they should always be supplemented by external appeals. One reason is the importance of an aggrieved party having one chance at least of putting its case before an external appeal authority which is independent of the administration. If there is a right to have one's case decided properly according to law, as I would argue there is, then that right would include the particular procedural right to an external appeal. A second reason is that the external appeal body may have a part to play, in addition to deciding the particular case, in developing more general standards and guidelines to be followed by officials in the specific area of administration. The educational, standard-setting role is potentially significant in raising the quality of decisions at the first instance and on internal appeal. Care does have to be taken, however, in not overstating the effectiveness of external bodies in this regard; empirical research shows clearly enough that the conditions necessary for the educational role to work well are not easily created in complex bureaucracies ${ }^{267}$.

While a compelling case can be made for some form of external appeal from administrative action, such mechanisms have their own shortcomings which should not be overlooked. One is cost. The creation of appeal bodies, no matter what form they take, is an expensive undertaking which may be beyond a country's means. Another matter to keep in mind is that external appeal procedures might not be invoked as frequently as would be expected. A study of the British social security system has shown that, although the quality of primary decisions is low, only a tiny percentage of disappointed claimants (less than 1\%) lodges appeals either internally or externally ${ }^{268}$. This is the case even though much emphasis has been put on creating a system of tribunals which is easy of access and informal in its procedures.

The point is that, in any context, resort to external appeals is likely to be severely limited, no matter how easy and attractive it is made to appear. Indeed, appeal apathy has been found to be deeply rooted. This phenomenon may in turn be linked to the role that legal or other specialist advice plays in appeal processes. Again it has been shown that one of the main variables in whether disappointed parties pursue their cases on appeal is the availability of specialist advice ${ }^{269}$. Advice is important not only in presenting the appeal but also at the prior stages; without suitable advice, the great majority of aggrieved parties will proceed no further.

In an ideal world, it would be good for each person who has been the subject of an administrative action to have ready access to legal advice. This could be provided by lawyers in private practice or by non-governmental agencies which develop expertise in a particular area. In either case the costs of

266 The British endeavours are analysed in J. Baldwin, N. Wikeley and R. Young, Judging Social Security (Clarendon, Oxford, 1993).

267 The issue is discussed in Baldwin, Whikeley, and Young, Judging Social Security (Clarendon, Oxford, 1993).

268 Baldwin, Whikeley, and Young, Judging Social Security.

269 See Genn and Genn, The Effectiveness of Representation before Tribunals (Lord Chancellor's Department, London, 1992). 
providing the service will be substantial and, since most persons affected will not be able to afford to pay, the only realistic approach would be for some form of publicly funded legal aid. That of course raises the question of resources, resources which most countries in the region will not be able to dedicate to this task. Another point to note here is the acute shortage of lawyers, especially lawyers willing to work in the area of public and administrative law. In interviews conducted for this study, the point was often made that there are few properly trained lawyers generally and that those who are tend to be attracted into practice in the commercial sector.

\subsection{Ombudsmen Devices}

\subsubsection{The General Idea}

One form of supervision of administrative action which has caught the imagination of many western countries is the ombudsman. The name itself is not especially helpful, but it has now become accepted as a general term to describe offices of considerable variety, but all having in common a general power to investigate complaints against governments and administrations. Although the ombudsman appears under various guises, the essential idea is an independent statutory body whose task is to investigate complaints made by individuals or groups about the actions of administrative authorities. Ombudsmen are sometimes given a very general and wide-ranging jurisdiction, at other times they are created with very specific areas of administration in mind.

For example, the role of the British Parliamentary Commissioner for Administration, who has a brief to investigate complaints against the departments of central government, is complemented by several special ombudsmen for matters such as prisons, the national health service, and customs and excise. Ombudsmen are generally created under statute, even sometimes by the constitution itself, and normally are answerable to parliament. Since their fundamental task is to investigate, scrutinise, and possibly criticise government and administration, it is essential that ombudsmen be statutory authorities independent of both. Ombudsmen are often linked directly to the parliament or national assembly, to which recommendations may be made and annual reports are usually submitted.

\subsubsection{Powers of Ombudsmen}

The powers of ombudsmen vary but a number of common features can be identified. For example, they are usually restricted to investigating individual complaints against the actions of an administrative body made by a person who is directly affected. The general idea is that the complaint should be investigated to determine whether there has been poor quality administration whether through negligence, ignorance, wilfulness, or sheer incompetence. It is sometimes suggested that the ombudsman should have a roving commission to investigate the administration in a more general way without being restricted to investigating individual complaints. Here again practice varies, but it is uncommon to find ombudsmen invested with general roving powers in addition to or separate from their primary function of investigating individual complaints. Other authorities, such as inspectors and commissions may have general powers, but they are usually quite separate from ombudsmen.

Another feature is that ombudsmen typically have the power to require the production of documents and other evidence. Officials may be questioned in the course of an investigation of a department or agency and may be required by law to answer and generally co-operate with the investigation. Further, where, in the course of their enquiries, ombudsmen find maladministration or other impropriety, they do not normally have the power to order a remedy backed by sanctions, but must be content to recommend to the 
administrative authority such a remedy or course of action as seems appropriate, leaving it to the conscience of the authority or the pressures of government and parliament to secure the required outcome. The most usual recommendations, where administrative impropriety has been discovered, is reconsideration or reversal of a decision or, if that is not possible, the payment of compensation.

\subsubsection{Rationale}

The idea that there should be mechanisms through which persons can lodge complaints about the way they have been treated by an administrative agency, other than by way of a more formal and structured appeal procedure, is inherently attractive. It is attractive from the complainant's point of view for two main reasons. One is that the process of investigation is initiated by simple complaint to the ombudsman who then takes over responsibility for the investigation. The other reason is that the scope of the investigation and the range of potential defects which may be inquired into are likely to be wider than in appeal procedures. Whereas on an appeal or review, even an appeal on the merits, it is usually necessary to show that a decision has been made or an act done which has some serious defect as to merits or as a matter of law, the ombudsman's investigation may range more widely.

The guiding criterion of maladministration or impropriety allows for scrutiny of a wide range of matters. These concepts may include but go well beyond mistakes of law or fact; they embrace a whole range of matters which constitute poor administration, and precisely what constitutes poor administration is often left pretty much for the ombudsman to decide.

From the point of view of the society generally, the virtue of the ombudsman's investigation is not only that it helps to resolve specific complaints, but also that it may contribute to better quality administration. In the first place, the investigation and correction of impropriety in specific cases is one way of improving the standard of administration. In the second place, in the course of an individualised investigation, the ombudsman may uncover more general and systemic maladministration. How far an ombudsman may inquire into general matters varies from one ombudsman to another and, indeed, how far such matters should be investigated is a matter of debate. The general point is that any ombudsman has some opportunity of looking beyond the strict confines of the particular case to take stock of more general administrative practices ${ }^{270}$.

The individual case and the general practice often are interconnected and cannot easily be separated; it makes good sense then that the ombudsman should have the power to make recommendations about the wider as well as the narrower issues. Any such recommendations may in turn be the catalyst for improving the administrative practices in question. With experience and practice over a number of years, an ombudsman's office will acquire considerable expertise which may be invaluable in providing advice and guidance to officials who, in their day to day affairs, do not have the time to stand back and review their own practices.

\subsubsection{Invoking the Ombudsman}

An important point to keep in mind in considering the creation of ombudsmen is whether people who feel aggrieved by administrative action will use them. It is one thing to create ombudsmen, another thing to get people to make complaints to them. Experience in the United Kingdom shows that, in general, only

270 A good discussion of these issues in the British context contained in M.Senevaratne, Ombudsmen in the

Public Sector (Open University Press, 1994). 
very moderate use is made of the considerable variety of ombudsmen's offices ${ }^{271}$. Of course the sheer numbers of complaints and investigations is not itself the most important test of the institution's success; but unless the level of use is reasonably high, it might be asked whether the burden on resources is worthwhile. Certainly some practical steps can be taken to encourage resort to ombudsmen: ease of access, informality of procedures, expeditious investigations and reports, and wide publicity - each step can help in that regard. One should be realistic, however, in recognising that it may take generations before complaints procedures, like the ombudsmen, really enter into the range of possibilities open to the average citizen.

\subsubsection{Ombudsmen in Central and Eastern Europe}

The creation of ombudsmen is a fairly novel matter in Central and Eastern Europe. In the countries studied here, only Hungary and Poland have so far entrenched the offices in their Constitutions and created them in practice. Albania, Bulgaria and Estonia are all considering the idea, but so far have not found it compelling enough to act on. It is interesting to note that Poland created its first ombudsmen in the early 1980 's. The first occupant of the office, Professor Letowska, a law professor of considerable strength of mind, gave the office, known as the Commission for Citizens' Rights, an independence and stature in the last years of communism which has continued into the democratic period. In Hungary, several offices of ombudsmen have been created in very recent years, the three most notable being the Commission for Civil Rights, the Commission for National and Ethnic Minority Rights, and the Commission for Data Protection.

One of the interesting points to emerge from Hungary and Poland is a very high level of complaints made by citizens to the various ombudsmen. In Poland, the Commission reported that in 1995 around 200000 letters had been received, from which about 45000 distinct complaints emerged. Of those complaints, around 10000 were thoroughly investigated. The Commission for Civil Rights in Hungary has also proved popular with approximately 30000 complaints having been made in its first year of operation. Whether these levels of complaints will be sustained, and to what extent they are the result of the offices becoming available, or, in the case of Poland more readily available, is hard to judge. It may be that the countries of the region have a citizenry which is more ready to complain than in some western countries; it could also be that they have more to complain about. The study of the ombudsman over the next few years will help to answer these questions.

\subsubsection{Ombudsmen and Other Forms of Supervision}

A final point to note here is the relationship between ombudsmen devices and other authorities and institutions which receive complaints. One interesting fact which my research in the area revealed is that people do complain fairly readily and that they do so to a host of authorities, including the department or agency which took the action, the minister responsible for the department or agency, the local office of the prosecutor, and the courts, especially the local branches. In Albania, it appears that even the Constitutional Court is the subject of numerous complaints about the administration. It could tentatively be concluded that, at least in the current period of democratic government, citizens are willing to complain and that a network of complaints mechanisms, often informal and without specific legal provision, are

being created. In the course of this study, I was not able to gather sufficient information on the extent of

271 Further discussion of this issue can be seen in D. J. Galligan, Due Process and Fair Procedures (Clarendon, Oxford, 1996). 
this phenomenon, but a general examination of complaints mechanisms and procedures in the region would be well-worthwhile conducting.

\subsection{Internal Complaints Procedures}

While the ombudsman provides a mechanism for investigating complaints which is external to the administration, brief mention should be made of the increasing trend in some jurisdictions to devise complaints procedures which are internal to the department or agency. This trend, which has gathered momentum in the United Kingdom, for example, is based on the idea that persons affected by a public authority ought to be able to make complaints to the authority itself about the way they have been treated. The authority for its part is expected to have in place procedures and mechanisms for dealing with the complaints.

Such complaints procedures are not to be confused with internal appeal procedures; the former supplement the latter by allowing for complaints to be made on a wide range of issues which would not be suitable grounds for an appeal. Complaints procedures within the National Health Service provide a good example: patients may lodge complaints about a great range of issues from such relatively trivial matters as rudeness by hospital staff, to more serious matters such as lack of information about treatment or defects in the treatment itself.

Complaints procedures vary greatly in matters of form and detail, but it may be worth noting several recurring characteristics. First, such procedures are geared to receiving complaints from aggrieved individuals, with emphasis placed on informality. Secondly, the authority is under a duty to investigate each complaint and to report its findings to the complainant. Thirdly, where good grounds for the complaint are made out, the authority may offer some form of redress. This may range across a spectrum from compensation at one end to a letter of apology at the other end. Fourthly, each authority is normally expected to create a complaints division which should be reasonably independent of the other parts of the bureaucracy. The authority is also responsible for devising suitable procedures and giving them wide publicity.

Without delving too deeply into such internal complaints procedures, a brief assessment of their merits and demerits may be offered. We may begin by noting the similarity between internal procedures and the ombudsmen. Both are based on individuals having complaints about their treatment by the bureaucracy inquired into by a special body; both emphasise informality and easy access; and both invite complaints on a wide range of issues going well beyond anything of a justiciable kind. Indeed, the similarity between the two systems leads one to wonder whether there is need for them both ${ }^{272}$.

The main merits of both systems are that, from the individual's standpoint, complaints even of a relatively unimportant kind are taken seriously, while the society's interest is served by possible improvements to the quality of administration, not least at the lowest and least visible levels. If there is any distinctive merit in internal systems it may be the relative ease and expedition with which complaints can be investigated and resolved. It may also be difficult for an external system to match the level of informality and ease of access open to internal systems. Amongst the demerits of a dual system is the risk that the proliferation of complaints procedures will lead to overlap and confusion. A possible demerit of internal systems internal complaints procedures, it made virtually no reference to the existing systems of ombudsmen. As a result, in the United Kingdom, the relationship between the two remains unclear. See further The Citizen's Charter: Raising the Standard (H.N.S.O Cm.1599, 1992). 
themselves is the difficulty in ensuring their independence from the very officials whose actions they are scrutinising.

The relationship between the two systems and the role that each might play in developing good quality administration needs fuller analysis than can be given here. The only conclusion I would suggest is that complaints mechanisms should be seen as a whole, within which internal procedures as well as external may have an important function. In creating such mechanisms, the task should be to identify and combine the relative strengths of each. The reader may find it useful here to make reference back to Section 2.4.4 where the range and variety of informal complaints procedures in the countries of Central and Western Europe are commented on.

\subsection{Inspectorates and Similar Bodies Exercising General Supervision}

Another form of supervisory authority of a non-judicial kind is the inspectorate, board, or special commission which has a general duty to oversee or scrutinise an area of administrative activity. The idea here is that an independent and specially constituted authority may be created to monitor, scrutinise, and criticise the actions, or some particular part of the actions, of a primary administrative authority. The main object of this form of oversight is to improve the quality of decision-making through extensive monitoring. With a general commission to examine administrative activity, inspectorates and the like complement the functions of ombudsmen; for while the former may initiate general investigations itself, the powers of the latter are normally triggered only by an individual complaint. The division between the two should not be drawn too strictly, since each may to a degree stray into the territory of the other; the division of functions is nevertheless useful and practical.

In France and the United Kingdom, inspectorates and similar bodies have a long history as a form of administrative supervision. Such institutions can be used as a way of supervising private activity, such as compliance with health and safety standards in the work place, as well as public functions. Here we are concerned only with the public aspect, although the usefulness of such bodies in monitoring the private sphere should not be overlooked. Inspectorates are commonly created to scrutinise the running of schools, prisons, hospitals, and universities, to take just a few examples. An Audit Commission or Cour des Comptes, as it is called in France, which is coming to be regarded as an especially important and effective form of scrutiny and supervision of administration, has similar powers with respect to the financial management of departments and agencies.

In France, the Conseil d'Etat itself began as a general supervisory authority over the administration, a role which continues today and which complements its judicial functions ${ }^{273}$. In addition to the jurisdiction of the Conseil d'Etat, the French system includes various other special supervisory bodies. In the countries of Central and Eastern Europe, the audit commission or something similar is now a usual part of the legal structure and, indeed, is often entrenched in the constitution of the country.

The powers of inspectorates and similar bodies naturally vary, but typically they include a general authority to inquire into some aspect of administrative behaviour. They may require the production of documents and the disclosure of information by the department or agency. In many cases, they may also question officials and require answers from them. Where defects or shortcomings are detected, an inspectorate may have the power to order their correction for the future. An annual report is usually

273 A description of the Conseil's powers of administrative supervision is contained in Bell and Brown, French Administrative Law. 
presented to parliament or the national assembly and published, while reports on specific matters may be prepared and published from time to time.

\subsection{Parliamentary Supervision}

The creation of parliaments, or national assemblies as they are often called, which are elected according to democratic procedures and which perform the usual functions familiar to such bodies in the west, is one of the most important features common to the countries of the region. Parliamentary institutions existed during the communist period, but they tended to have few powers and to be composed of one political party. In the democratic period, the powers of parliaments vary, but in general they are the central legislative authorities.

In addition to their legislative activities, however, parliaments can perform important supervisory functions over the administration. Those functions can be performed through two different sets of mechanisms. One set of mechanisms is conducted within the parliamentary chamber itself, while the other is relegated to the committees of parliament. The former consists in debates on issues of administration, questions raised by deputies, and statements and explanations from ministers. The latter, the committee system, consists in the creation of a range of committees of parliament each of which is responsible for oversight of a particular area of government and administration.

The committees may be of different kinds, but a standard distinction is between permanent committees with continuing powers and duties, and $a d$ hoc or temporary committees created to perform a particular task. The committees are composed of members of parliament, usually with assistance from expert advisors. The tasks of the committees normally divide into legislative and supervisory. In their legislative capacity, the committees play a major role in examining draft legislation and commenting on it. In their supervisory role, the committees may inquire into issues of government and administration. In the following pages, I shall comment briefly on the role of committees in each of the five countries being studied.

\subsection{The Objects and Importance of Supervision}

Much has been said in the preceding discussion about the objectives sought to be achieved by the different forms of supervision and why they are important. It may be helpful, however, briefly to summarise those objectives and to link them to underlying principles and values. The main, if not overriding, object of the forms of supervision of the administration is to achieve good quality administration. That does not, however, tell us very much unless the notion of good quality administration is analysed more fully. In its most general sense, administration is of good quality if actions are being taken which fulfil the purposes for which power to take those actions has been conferred by statute or legal authority, in a manner which is as economical as possible.

Administration, in other words, is purposive; its purposes are defined by law and its acts and decisions ought to be directed to the fulfilment of those purposes. In a world of limited resources, administration will not be perfect, but it should be conducted as efficiently as possible within the resources available. The amount of resources available in any area will depend on the society's wider aims and goals. So it may be said that good quality administration serves the good of society by being an instrument for the effective realisation of society's aims and goals as expressed through its laws.

This general approach now needs to be made more complete by adding two vital elements: one is a set of intermediate standards which help to define and give content to the notion of good quality administration; 
the other is the special concerns raised by the fact that administration affects the rights and interests of individual citizens. With regard to the first of these, the idea is that, in addition to a general concern that administrative powers be used effectively and efficiently, more specific standards can be devised which are indicators of good quality administration.

The standards include: following the procedures laid down, including hearing and other participatory procedures; acting impartially and without bias; protecting against corruption; disclosing documents and information relevant to the issues in each context; interpreting and applying the law accurately; exercising discretion in good faith and taking account of relevant factors; giving full reasons for actions; and generally having in place adequate mechanisms for checking the quality of actions. The point about such standards is that each contributes to good quality administration, so that the higher the levels of compliance with them, the more confidence one can have that that objective is being achieved in both the particular case and in general.

Not all administrative action affects individual persons, but much of it does and where it does an extra dimension is added. The extra dimension is that administration should be conducted in a way which respects the rights of persons and treats them fairly. Fair treatment and respect for rights may be regarded as goods in themselves and amongst the major objectives of supervisory mechanisms. The same objective should also be seen as an element in good administration. There is more to good administration than achieving the purposes of authority in a manner which is efficient; it is equally important that it should be conducted in a manner which respects rights and ensures fair treatment. The two ideas of course overlap, since administration, which effectively pursues purposes, at the same time respects the rights of citizens contained within those purposes.

A system of social security, for example, conducted for the right purposes, according to the accurate application of legal standards, will at the same time mean giving effect to the rights conferred by the standards. Accordingly, several of the intermediate standards referred to above will advance the quality of administration, while at the same time demonstrating respect for the rights and fair treatment of the parties affected. Openness and transparency in administration, for example, are indicators of good quality decision-making, but should also be regarded as recognition that individuals have a right to be treated according to a certain kind of process.

Respect for rights and the fair treatment of persons may also add certain standards, or at least lead to existing standards being given a certain meaning and emphasis. The very idea, that the administration should try to decide cases by the accurate application of the law, is itself given a special focus when the task is to decide what people's rights are under the law, rather than what colour the buses should be painted. Where rights or important interests are at stake, accuracy is important not just in order to be efficient, but because an inaccurate decision may mean that rights are wrongly denied. Other standards, such as the hearing principle, the need for impartiality, and the giving of reasons serve good administration in a general way, but are also given a special emphasis because they are linked to respect for rights,

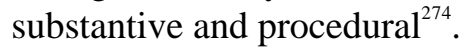

274 For further discussion, see D. J. Galligan, Due Process and Fair Procedures. 


\section{B. FORMS OF SUPERVISION IN HUNGARY, POLAND, BULGARIA, ESTONIA, AND ALBANIA}

\section{Introduction}

The first section of Part II of the report was devoted to an analysis of the principal forms of supervision of the administration, both judicial and non-judicial. The task in this second section is to study the law and the practice of each of the five countries. This analysis leads to, in a third section, some comparisons and evaluations across the countries.

The pattern followed is, first, to give an overview of the general approach of each country and the progress that has been made. Next, a more detailed account is given of the various forms of supervision. Finally, a concluding paragraph proposes questions for debate within the context of improving current mechanisms.

This part of the report addresses only supervisory mechanisms which are external to the administration. Appeal procedures, which are internal to the administration, are covered in Part I. As can be seen from Part I, internal administrative appeals are an essential component of the administrative law systems of the region's countries.

This part of the report addresses only supervisory mechanisms which are external to the administration. Appeal procedures, which are internal to the administration, are covered in Part I. As can be seen from Part I, internal administrative appeals are an essential component of the administrative law systems of the region's countries.

This approach to administrative law can be linked to the idea that the administration should supervise itself, rather than be subject to external scrutiny. This idea, which has perhaps long been latent in the countries of Central and Eastern Europe, was propelled onto centre stage during the communist period and fits well with the total control over the administration which the logic of one party rule dictates. In the years of change and reform, most countries in the region have retained this basic approach to administrative law, with the administration having primary responsibility for supervising itself. Around this central characteristic, however, several forms of external supervision, ranging from judicial review, across ombudsmen, to the work of parliamentary committees, have been added.

The result is a diversity of forms of supervision as each of the countries strives to put in place, in one form or another, the main forms of supervision discussed in Part I of this report. But while the emphasis in recent years has been on opening the administration to scrutiny by external institutions, it should be remembered that the commitment to primary internal supervision remains. The consequence is a certain tension between the two. 


\section{Objectives and Methods}

The main objective in this section of the report is to describe and analyse the forms and methods of supervision, both judicial and non-judicial, as they exist or are being developed in Hungary, Poland, Bulgaria, Estonia, and Albania. In making the analysis, I shall be guided by the following more specific objectives to:

- $\quad$ identify and describe the main forms of supervision of the administration;

- $\quad$ give a brief account of the background of those forms in each country;

- $\quad$ indicate current proposals for change and innovation in each country; and

- $\quad$ offer a general comparison and evaluation across the five countries.

As in Part I of this report, the analysis here goes beyond merely describing the current state of the law. The current state of the law is of course of great importance, and it has not been easy to gain a comprehensive, accurate understanding of the law in each country. However, to stop with a description of the legal position would be of limited value. I have tried wherever possible to gain some understanding of the context in which the forms of supervision operate and to form an idea of how they are working in practice. This last task I shall attempt to do in this report. The gap is always wide between legal codes as they appear in the books and what happens in daily practice in the agencies and departments of government.

Since law is meant to be a practical guide to action, it is vitally important that it should be applied in the way it is intended. That can never be achieved perfectly, but it can be achieved at all only if an effort is made to understand what happens in the social reality of different administrative bodies. This is not to say that law and social reality are two different and incompatible concepts; on the contrary, law is part of social reality and exerts great influence on the way officials and parties understand their social environment. The great challenge in reforming the law or in developing new legal approaches is to understand the social context so that the law can be both responsive to it and capable of exerting greater influence over it.

Now of course to understand fully how administrative law and procedure works would require major empirical studies which do not exist either in western or eastern European countries. In recent years, however, the interest of researchers in these matters has grown and empirical studies of particular issues are being conducted. I shall draw on those studies wherever possible in compiling this report. I shall also draw on a study referred to in Part I entitled Administrative Justice in Central and Eastern Europe (referred to as the Administrative Justice Project).

The object of the study is to learn how administrative laws, procedures, and institutions work in selected countries of Central and Eastern Europe. This is done by conducting six case studies in each country of different administrative processes, the idea being that each will demonstrate interesting and significant features of administrative law and practice. The countries being studied are Bulgaria, Estonia, Hungary, Poland and Ukraine. Since the first four countries are, together with Albania, the subject of this report, some aspects of the Administrative Justice Project will be drawn on in gaining an inkling of how administrative law works in practice.

In preparing this report, the primary materials on which I have relied are the laws and regulations of each of the countries. The laws and regulations of the five countries relevant to the issue of administrative procedures, with few exceptions, have been collected and translated into English through the good offices of the SIGMA Secretariat. Apart from the interest of the report itself, the collection and translation of these laws is a valuable by-product of this project. 
While an analysis of the relevant laws and regulations is the basis of this part of the report, use has also been made of secondary materials, in the form of articles or reports, which have dealt with issues of procedure. The analysis of the laws and regulations was followed by a series of extensive interviews which I conducted in each of the five countries. Those interviewed usually included senior officials from the ministry of justice and other ministries with an interest. Interviews were conducted also with judges from various courts, although I concentrated on those involved in administrative cases. The issues here were also discussed with lawyers, university teachers and scholars, and assorted other relevant parties. Interviews were sometimes conducted in English, sometimes in the interviewee's native language through an interpreter. Although time was limited and only a small selection of interested persons could be interviewed, those with whom I did discuss these matters were very generous with their time and enormously valuable in helping me to understand better the issues of administrative procedures for each country.

\section{Hungary}

\subsection{Overview}

Reasonable progress has been made in Hungary in creating mechanisms of administrative supervision. Judicial review of administrative action on grounds of legality is provided for in the Constitution ${ }^{275}$ and then given more specific treatment in the General Rules of State Administration Procedures ${ }^{276}$. No provision is made for appeal on the merits to an external court or tribunal; issues of merits are confined to the internal, administrative appeals system ${ }^{277}$. An ombudsmen system is provided for in the Constitution; two offices are envisaged, a Commissioner for Civil Rights whose task is to investigate complaints of abuse of constitutional rights, and a Commissioner for National and Ethnic Minority Rights ${ }^{278}$. Appointments have been made to both offices and both have recently been put into operation. A third office, the Commission for Data Protection, has also been created and has begun to receive complaints.

Amongst supervisory authorities of a general kind, the Prosecutor has a constitutional duty to protect the rights of citizens and to safeguard the legality of administrative actions: Constitution A.51. These duties are spelt out more fully in The Prosecution Act of 1972 (with amendments). The Constitution ${ }^{279}$ has created an Audit Office, which has extensive supervisory powers in relation to financial and economic matters. Provision is made in the Police $A c t^{280}$ for the Minister of the Interior to create mechanisms for supervising the police, but no action has so far been taken. The Government has a constitutional duty to supervise the lawfulness of local government ${ }^{281}$, but it is not clear what practical steps have been taken to discharge that duty.

Under the Standing Orders of Parliament, a framework is created for Standing Committees which could have a significant role in overseeing the administration. Many of the committees are now in operation and their members have been appointed. The Standing Orders also allow Parliament to appoint Committees of

275

276

277

278

279

280

281

Article 50(2).

Section $72 \mathrm{ff}$ as amended in 1991.

Internal appeals are described in Part I of this report.

Article 32.

Article 32c.

Act XXIV of 1994.

Article 35 (1) d. 
Inquiry to examine specific matters of government and administration. This power has been exercised by the Parliament but, so far, on a very limited basis.

These various mechanisms are described more fully below, but two general comments should be made at this stage. The first is that, despite some progress, Hungary does not yet have a sufficiently comprehensive system of judicial and non-judicial supervision. Significant gaps remain to be filled. Secondly, practical action has been slow in following legal provision, with the result that several laws providing for the creation of institutions and procedures have yet to be implemented.

\subsection{Judicial Review}

The basis of judicial review of administrative action is Article 50.2 of the Constitution which provides that the courts shall review the legality of the decisions of public administration. This is supported by Article 57.5 which confers a right on each person to seek a remedy against administrative actions which infringe the rights or interests of that person. This provision would clearly include judicial review for legality, although presumably it envisages also remedies in addition to judicial review. Although in the English translation of the Constitution, the word "decision" is used, this is not meant to be a narrow term of art and may be taken to include administrative action in a wide and general sense.

The general constitutional duty of the courts to review administrative action is given more precise legislative application in the General Rules of State Administration Procedure ${ }^{282}$. Under the General Rules, a person whose interests are affected by an act or decision, whether or not the person is directly subject to the act or decision, may bring an application in the courts within thirty days of the act or decision for review on the grounds of legality ${ }^{283}$. Where internal administrative appeals exist, they must first be exhausted.

Once an application for review is lodged, enforcement of the act or decision is suspended, although the administrative authority may declare that an action should take immediate effect, if the public interest or the interest of a person directly affected by the action so requires. The general and open nature of the two conditions suggest that the authority has a significant discretion in deciding whether to order immediate implementation. The exercise of that discretion can be challenged in the courts if it is in breach of the law or in some way wrongly used. The courts, however, have no authority to overturn the exercise of discretion on the grounds simply that they disagree with it. Certain categories of administrative action are excluded from review: examples are where review is expressly excluded by law, or where the administrative action concerns the distribution of foreign trade goods or matters relating to defence and security ${ }^{284}$. The list of exclusions is extensive and consideration ought to be given to whether all the exclusions are justified. The presumption in favour of judicial review should be very strong, subject to exclusions only in clear and pressing cases.

If the court finds a breach of legality, it shall declare the action to be invalid and may order the administrative authority to remake the decision ${ }^{285}$. The court may itself change the act or decision if expressly authorised by law to do so $^{286}$. Once the court has passed judgement, on the essential point of an

282 Act IV of 1957: referred to as the General Rules.

283 Section 72.

284 Section 72.4.

285 Section 73.

286 Section 74. 
action, an administrative authority may not make another decision on the same issue. Administrative authorities are of course bound in any future action by the terms of a court decision.

The Constitution allows for the creation of special courts ${ }^{287}$, but so far administrative courts have not been established. The prevailing view amongst senior officials appears to be that separate administrative courts are not necessary. A separate system would require substantial resources and it is felt that the existing court structure is adequate. Review of administrative action is conducted by a special division of the ordinary civil courts whose procedures are governed by the Civil Procedure Code. Under the Civil Procedure Code, an appeal from the decision of the court of first instance to the higher courts may be sought in some cases.

Although different opinions may be detected about the need or not for special administrative courts, there is a concern amongst officials and lawyers that judges deciding appeals from administrative action do need special training. It is not clear that such special training is currently available. The view was also expressed that there is a case for a special code of procedure in administrative appeals to the courts. The point is that administrative cases are distinctive and raise issues different from those of an ordinary civil action between two parties. However, there is little evidence of any real move towards a special code of administrative procedures.

In the course of my interviews with Hungarian lawyers, officials, and academics, it became clear that great store is placed on judicial review of administrative action. It is regarded as a vital element in developing a sound culture of administration under law; considerable hope is held out that judicial review will have a significant and beneficial impact on the administration. Indeed, greater emphasis appears to be placed on judicial review than on internal administrative appeals, even though the former is confined to matters of legality. It may be, however, that the Hungarian courts will construe legality in such a broad and open way that it may become an effective method of supervision going beyond the strict letter of the law.

\section{3. $\quad$ Appeal on the Merits}

There is no general provision in Hungary for an appeal to a court or court-like body on the merits of an administrative action, that is, on its content and substance. Special provision for such appeals are sometimes made in specific laws, but this does not appear to be a common practice. It should be said, however, that it was not possible in the course of this study to investigate in any detail special appeal jurisdictions.

\subsection{The Prosecutor}

The Prosecutor or Procuracy is created by Article 51 of the Constitution and the public law function of the office is stated to be to ensure that the law is observed by all social organisations, state bodies, and citizens. Where violations of the law come to the attention of the Prosecutor's office, it is required to take such measures to remedy the violation as are provided for by law. The Act on the Prosecution ${ }^{288}$ spells out in more detail the duties of the Prosecutor.

The general powers and duties of the Prosecutor General of the Republic of Hungary, as defined in the Act on the Prosecution, are extensive. I shall not examine them in any detail here, but they include the right to

Article 45.2.

288 Act V of 1972 as amended in 1989. 
attend Parliament in an advisory capacity, to amend rules issued by the Council of Ministers or individual Ministers, and to propose amendments to legislation. The office may initiate rulings by the Supreme Court and submit motions to the Constitutional Court for Rulings on constitutional issues.

For present purposes, the main point of interest is the role of the Prosecutor in supervising the administration. The Act on the Prosecution follows the Constitution in declaring that the Prosecutor shall take part in enforcing the law, in initiating action related to constitutional supervision, and in protecting legality ${ }^{289}$. The point of particular interest here is the Prosecutor's role in supervising the activities of the administration. In discharging its duties of supervision of legality, the Prosecutor's office shall act as public attorney in the course of judicial proceedings; it shall participate in administrative law procedures and contribute to the observance of the law by administrative bodies ${ }^{290}$. The Prosecutor is required to supervise the legality and constitutionality of both normative acts and individualised decisions of the administration $^{291}$. While the Prosecutor may learn of possible illegality through the initiative of his office, matters will often be brought to his attention by the complaints of citizens and organisations. The Prosecutor is under a duty to examine complaints made to his office and to take suitable action where the law has been violated by an administrative body.

The measures to be taken by the Prosecutor and the procedures to be followed are stated in detail in the Act on the Prosecution. Without examining these measures and procedures in detail, the general idea is that the Prosecutor's office should first lodge a protest with the administrative body responsible for the act or decision, or with the superior administrative body ${ }^{292}$. The protest should be considered by the primary decision-making body or the superior authority, as appropriate. If it agrees with the Prosecutor's case, then it should take action to remedy the violation; if it does not agree, then the Prosecutor may take the matter to the ordinary courts ${ }^{293}$ or, where constitutional issues arise, to the Constitutional Court ${ }^{294}$. The Prosecutor has powers of supervision not only with respect to acts or decisions, but also with respect to omissions and threatened future acts ${ }^{295}$.

The precise nature and role of the office of Prosecutor in Hungary has undergone several changes since its inception in 1871. From originally following the Prussian model and being concerned mainly with penal matters, during the communist period the office assumed extensive public law powers. At a time when judicial scrutiny of the administration was virtually non-existent, the Prosecutor became the main custodian of legality, whether on the part of the state and administration, social organisations, or citizens. In this respect, the Hungarian approach was influenced by the Soviet model within which the Prosecutor acquired very extensive powers and was greatly feared. In the post-communism period, the Prosecutor's office has been retained, although the 1972 law has been substantially amended and the powers of the office reduced.

Amongst those interviewed in the course of this study, opinions differed about the merits of retaining the office at all, especially since the courts now have extensive powers of review and since they are directly accessible to citizens. One significant advantage of the Prosecutor's role is the power to intervene at an early stage, to investigate a potentially unlawful action or practice, and to urge the administration to

289

290

291

292

293

294

295
Articles 1 and 3 .

Article 3.

Article 13.

Article 13ff.

Article 15.5.

Article 13.3.

Article 16. 
remedy the matter itself. The Prosecutor's office has an early opportunity of intervening; it also has a direct line to the different levels of government and administration from the highest to the lowest. A second advantage of the office is that it may take action with respect to a general administrative practice, as well as a specific act or decision. The office remains very active in these matters and in any year conducts several thousand investigations into administrative activity, many of which are followed by recommendations for change.

Another interesting feature of the office in Hungary is that it has local branches, as well as a central headquarters, which serve various functions in addition to those strictly conferred by law. At the local level, indeed, the Prosecutor's office often looks like a kind of ombudsman, receiving and investigating complaints, and sometimes making recommendations even where perhaps strict issues of legality are not in issue. This ombudsman-like function is encouraged by the absence of local and regional offices of the two ombudsmen, both of which are centralised in Budapest. It should also be remembered that the Commission for Civil Rights and the Commission for National and Ethnic Minority Rights are both confined to constitutional rights, while the Prosecutor may examine issues of legality generally. There is undoubtedly some overlap between the two Commissions on the one hand and the Prosecutor on the other, but the general view amongst officials and lawyers is that the two nicely complement each other.

\subsection{Internal Complaints Procedures}

While the General Rules create a network of appeals from primary administrative authorities to superior ones $^{296}$, special complaints to deal with specific issues are also occasionally found in Hungary. Considerable diversity can be seen across the types of complaints procedures, with a range of institutions and procedures for dealing with different issues. The idea common to many such procedures is that a person who is dissatisfied with the treatment received by an administrative body may lodge a complaint with an institution created for that purpose. This should not be confused with internal appeals, although the two different procedures might often deal with the same or similar issues.

It has not been possible in the course of this study to examine internal complaints procedure, except to note that various networks exist. It is also important to draw attention to Article 64 of the Constitution which emphasises a long-recognised right in Hungarians to submit petitions or complaints to state organisations and administrative bodies. A study of the formal and informal complaints procedures remains to be undertaken and would be well worthwhile.

\subsection{Ombudsmen}

The Constitution of Hungary provides for the creation of three kinds of ombudsmen: a Commissioner of Civil Rights, a Commissioner for National and Ethnic Minority Rights, and special commissioners who are to have responsibility for certain specific constitutional rights ${ }^{297}$. The first two have now been appointed and, under the third category, a special Commissioner for Data Protection and Freedom of Information has also been created ${ }^{298}$. All three Commissioners were elected by the Hungarian Parliament on 30th June 1995. Although each Commissioner is separate and independent, for financial and practical

\footnotetext{
296 See Part I of this report.

297 Constitution, Article 32B.

298 Law on the Protection of Personal Data and the Disclosure of Data of Public Interest (Act No. LXIII of 1992 as amended; referred to as the Law on Data Protection).
} 
reasons, the three offices have been integrated into a common organisation based in Budapest. There are no local or regional offices.

The primary duties of the Parliamentary Commissioners (and I shall refer to the offices collectively) are to investigate alleged violations of constitutional rights by the government and administration, and to take measures, whether of a general or individual nature, to remedy the violations. The rights referred to are expressed at length in chapter 12 of the Constitution. The constitutional provisions are given fuller expression in the Law on the Parliamentary Commissioner for Civil Rights ${ }^{299}$ and the Law on Data Protection. The Parliament elects the Commissioners. In this analysis, I shall concentrate on the powers and duties of the Commission for Civil Rights and the Commission for Ethnic and Minority Rights.

The powers and duties of the Parliamentary Commissioners as expressed in the Constitution and the procedures to be followed are stated in detail in the Law on the Parliamentary Commissioner for Civil Rights. A Commissioner's investigation of the administration is normally triggered by a complaint from an interested party ${ }^{300}$, but the Commissioners also have the power to act on their own knowledge ${ }^{301}$. An interested party for this purpose is a person who has suffered injury to his rights as a result of the action of an administrative body. A party must first exhaust other forms of recourse open, although this presumably refers to internal administrative appeals or other forms of complaints rather than judicial review. The main concern of the Commissioners is to investigate and resolve individual complaints, but the Commissioners may take measures of a more general kind.

The full scope of the Commissioners' general powers is not entirely clear, but includes at least the following two aspects. One is to use the investigation of a complaint about a specific issue as a means for uncovering and making recommendations about more general practices within the administrative organisation. The other is a general power in the Commissioners to make recommendations about laws, regulations, and other normative acts, or the absence of such normative acts, which in some respect constitute a breach of constitutional rights ${ }^{302}$. The Commissioners may propose the amendment, repeal, or issue of a legal rule.

The jurisdiction of the Commissioners is extensive and covers the full spectrum of administrative authorities, including the police, local governments, and the armed forces, in addition to the agencies and departments of central government ${ }^{303}$. The commissioners' jurisdiction covers organisations which perform a public service even though not part of the administration. However, the Commissioners' powers are limited functionally in that they are confined to acts or omissions in respect of constitutional rights ${ }^{304}$. This means that they have no jurisdiction in matters of administrative action which do not involve constitutional rights.

In conducting an investigation, the Commissioners have extensive powers to request the supply of information by the administrative authority ${ }^{305}$. The Commissioners may inspect documents, request a written explanation, and conduct a hearing of the officials involved. Some restrictions are imposed on the Commissioners' inspection of documents relating to the armed forces and national security, but the

Act No. LIX of 1993.

301 Article 16.2.

302 Article 25.

$303 \quad$ Articles 16.1 and 29.

304 Article 16.

$305 \quad$ Article 17.2. 
Commissioners are not prohibited from gathering information which is covered by the provisions relating to state and service secrets.

The measures to be taken by the Commissioners, if they discover a breach of constitutional rights, are set out in detail in the Law on the Parliamentary Commissioner for Civil Rights. Briefly stated, the steps are as follows. First, the Commissioners should bring the matter to the attention of both the primary authority and the supervisory authority responsible for the primary authority ${ }^{306}$. Secondly, the primary body should consider whether it can remedy the abuse. Thirdly, if the primary body does not agree with the Commissioner's conclusion, it shall submit the matter to its superior authority. The latter shall then take or direct the necessary measures. Fourthly, if the abuse is not remedied, the Commissioner may submit the case to Parliament and request that the legislative body investigate the matter ${ }^{307}$.

While it is too early to gauge the practical workings and effectiveness of the Commissioners, a few brief observations should be made. The first is that, in the first year of operation, they received a large number of complaints, although the precise figures are not available. The largest area of complaints was alleged breaches of civil rights, where around 5000 were received. Fewer complaints were received in the areas of minorities and data protection, but the complaints that were made in these matters often involved many people and raised complex issues. A second observation is that, at least at this early stage, government and administration are submissive and co-operative in their attitudes to the Commissioners. It was noted in this regard that the lack of coercive powers on the part of the Commissioners is offset by the effectiveness that can be achieved by adverse publicity of recalcitrant administrative authorities.

The third point to note is that the offices of the Commissioners are very small and are likely soon to be swamped by a volume of complaints beyond their capacity to handle. It is also significant that the Commissioners do not have local or regional offices. The consequences of this very centralised organisation are not yet apparent, but to many Hungarians the ombudsmen must seem remote. Fourthly, it should be observed that so far the Commissioners' offices have spent their time reacting to complaints rather than invoking their more proactive powers of investigation. Considering the scarcity of resources, it is likely to be very difficult for the Commissioners to develop that aspect of their powers. The final point is that the Commissioners put noticeable emphasis on the educative role their work can have, educative, that is, of both the administration and the citizens, the former as to its responsibilities, the latter as to its rights.

\subsection{Inspectorates, Commissions, and other Forms of Special Supervision}

One form of supervision of special significance in Hungary is the State Audit Office. It is provided for in the Constitution $^{308}$ and is the body of financial and economic control over Parliament, government, and administration. The main task of the State Audit Office is to supervise the proper use of state finances; in doing so, it should be guided by considerations of legality, expediency, and efficiency ${ }^{309}$. The State Audit Office is bound to report to Parliament on its supervisory activities.

Although not provided for in the Constitution, various other inspectorates and commissions have been created by Parliament to exercise supervisory roles over particular parts of government and administration. I shall not attempt to describe or even to list the different bodies, although one of particular importance for

306 Section 20.

307 Section 22.

308 Article 32C.

309 Article 32C.2. 
good government is the Public Procurement Council, which has responsibility for overseeing the proper application of the rules of public procurement ${ }^{310}$.

\subsection{Parliamentary Supervision}

The Hungarian Parliament may potentially play an active and significant role in supervising the executive and administration. Detailed rules are laid down in the Standing Orders of Parliament (1994). The rules should facilitate the functioning of Parliament generally and the performance of a supervisory role through debates, questions, and motions.

Proceedings in the chamber itself may be complemented by the activities of the committee system, for which provision is made in the Constitution ${ }^{311}$. The Constitution also states that everyone, including presumably administrative authorities, shall produce information to a committee as required ${ }^{312}$. The Standing Orders make provision for three kinds of committees: standing committees, ad hoc committees, and committees of inquiry ${ }^{313}$. The main standing committees, which are mandatory and of which there are around seventeen, include committees dealing with constitutional matters, the budget, foreign affairs, and national defence ${ }^{314}$. The membership of committees is made up of deputies of Parliament in proportion to their factional strength. In addition to their powers to offer opinions and make proposals, the standing committees are under a duty to be involved in the supervision of government and administration ${ }^{315}$.

The committees may initiate inquiries into aspects of administration and may exercise a supervisory role over central departments. The committees' working methodology is to ascertain the facts and to make recommendations to the Parliament. Provision is made for the appointment of sub-committees, one of the tasks of which is to monitor the implementation of laws coming within the competence of the committee $^{316}$. The standing committees report to Parliament and may make recommendations ${ }^{317}$. The committees usually have a small core of staff who are experts in the particular field and who can offer advice to them.

Ad hoc committees may be created by Parliament from time to time to deal with specific issues ${ }^{318}$, while committees of inquiry will be charged by Parliament with the investigation of particular matters. Committees of inquiry can be set up at the initiative of the opposition parties and cannot be prevented by an unwilling government. The Committees are required to report to Parliament on their proceedings and findings, and where appropriate to propose that suitable measure be taken ${ }^{319}$.

Hungary has done well in establishing a full and functioning committee system in a few short years. The system is still at its early stage of development and it is difficult to say how effective it is as a set of mechanisms of supervision of the government and administration. The main need at present appears to be

310 The rules are stated in Act XL of 1995 entitled On Public Procurements.

311 Article 21.

$312 \quad$ Article 21.3.

$313 \quad$ Sections 0.28 and 34 .

314 Section 0.28 .

315 Section 0.29.

316 Section 0.29.3.

317 Section 0.95 .

318 Section 0.34 .

319 Section 0.36 . 
to nurture a parliamentary culture, which includes a vigorous committee system: this in turn means gaining the experience and confidence which comes with time and determination.

\subsection{Conclusions and Matters for Consideration}

Hungary has made good progress in creating the main forms and institutions of supervision of the administration. A system of judicial review was initiated before 1989 and has been extended since. It is placed on a sound legal footing and is attracting significant numbers of applications. Its jurisdiction is limited by the need for a party first to exhaust internal administrative appeals, but it is too early to say how the relationship between the two will work out. The need for judges to be well-trained in administrative law will require more attention than presently given; similarly, the shortage of lawyers with expertise and interest in this area may raise important issues for legal education and careers. It is also important that the superior courts gradually build up a jurisprudence of administrative law principles. The extent to which this is already being done is not clear and warrants a study of its own.

The major potential gap in the Hungarian system is the absence of provision for review of the merits and substance of administrative actions by a court or special tribunal which is independent of the administration. This is one area in which Hungary would benefit from the experience of other countries like Australia and the United Kingdom.

In the non-judicial sphere, careful consideration should be given to the role of the Prosecutor in a modern, democratic country. The present position is complex and reveals a certain tension between the function of the office under the old, communist dispensation and its position in the new order. A resolution of this tension should be achieved by reaching a clear view of the role of the office and then reflecting that in a new law. The other matter to address is the relationship between the Prosecutor and the Parliamentary Commissioners. This is currently rather murky and confusing. It would be wise, in the course of considering the Prosecutor's general role, to examine carefully the relationship between those two institutions and to produce laws in which the relationship is clearly reflected.

It has not been possible in the course of this study to examine the various forms of inspectorates and commissions, such as the Audit Office. Such bodies are coming to have an appreciable supervisory role in modern democracies, and a study of the Hungarian arrangements would be worthwhile. And finally, at the Parliamentary level, Hungary has put in place a comprehensive network of committees which have the potential to become effective mechanisms of scrutiny and supervision. A great deal will turn on how well that potential is realised in practice.

It is suggested that consideration be given to the:

i. $\quad$ training of judges in administrative law;

ii. shortage of lawyers practising in administrative law;

iii. creation of appeals on the merits of administrative action to a court or court-like body which is independent of the administration;

iv. role of the Prosecutor in supervising administrative bodies;

v. possible extension of the scope of authority of the Parliamentary Commissioners;

vi. adequacy of inspectorates and special boards and commissioners across the spectrum of public administration; 
vii. improvement of the effectiveness of parliamentary committees as mechanisms of supervision of the administration.

\section{Poland}

\subsection{Overview}

Amongst the provisions of the Constitution of 1952 which continue in force, Article 86.2 states that citizens have the right to approach all state authorities with complaints and grievances. It further states that such complaints and grievances shall be examined and settled justly and without delay ${ }^{320}$. The practical application of those rights depends of course on detailed laws creating suitable forms and procedures. This provision, however, which is common in many countries in the region does create a constitutional basis for various forms and institutions of supervision.

Of greater importance are the legal arrangements for judicial review of administrative action. Neither the Constitution of 1952 nor the Small Constitution of 1992 make express provision for judicial review of administrative action on the grounds of legality. The only relevant statement of principle is to be found in Article 3 of the original Constitution which declares that "all the organisations of state authority and administration shall work on the basis of compliance with the law". Provision is made in the Constitution of 1952 for the administration of justice to be vested in the "Supreme Court, the common courts, and special courts" ${ }^{321}$.

The Administrative Procedure Act $t^{32}$ made limited provision for judicial review of administrative action, provided that internal administrative appeals had first been exhausted ${ }^{323}$. Judicial review was exercised by the ordinary courts ${ }^{324}$. A Supreme Administrative Court was created to perform the task of judicial review of administrative action. A major new law was enacted in 1995, the Supreme Administrative Court Act and came into effect in 1996. The new law makes some important changes to the Supreme Administrative Court and, most significantly, increased its jurisdiction over administrative actions.

Other forms of supervision of the administration in Poland include the Prosecutor, the Commissioner for Citizens' Rights, and the National Audit office and similar kinds of inspectorates. The Polish parliament, consisting of the Sejm and the Senate, has an extensive system of committees which have an important supervisory role over the government and administration. The Prosecutor's powers have been greatly reduced in the democratic period, although the office retains its constitutional duty to safeguard observance of the laws by administrative authorities ${ }^{325}$. In creating the office of Commissioner for Citizens' Rights in 1987, Poland was the first country in the region to adopt an ombudsman. The first Commissioner ensured that the office was independent of the government and won respect for it. It continues in that vein and has become an important form of supervision. The two constitutions and practical workings are discussed in more detail below.

Article 86.3.

Article 56.1

1960 (as amended).

Internal appeals are discussed in Part I of this report.

Created under the Supreme Administrative Court Act (Act No. 74 of 1995).

Small Constitution of 1992, Article 64. 


\subsection{Judicial Review}

The highest level of judicial review in Poland is exercised by the Constitutional Court ${ }^{326}$. The Court has a duty to adjudicate on the conformity of laws and other normative acts with the Small Constitution. The jurisdiction, organisation, and procedure is to be stated in a separate $\operatorname{law}^{327}$, but that has not yet been done. A second body called the Tribunal of State has jurisdiction to determine responsibility for breaches of the Constitution and laws by persons holding high State offices ${ }^{328}$.

The most important form of judicial review of administrative action in Poland is that exercised by the Supreme Administrative Court. A person dissatisfied with a decision of an administrative authority may lodge a complaint with the administrative court ${ }^{329}$. The right to seek judicial review in this way is not spelt out in detail. During the communist period in Poland, the right to seek judicial review was not often exercised, since the emphasis in the Administrative Procedure Act is on settling grievances within the appeal structure of the administration itself ${ }^{330}$. However, in 1980, limited judicial review of the administration was introduced and administrative courts were established. In the following years, judicial review gradually became more readily available; since the end of communism, it has become a straightforward procedure and is used extensively.

The culmination of the reform process in this context was the recent enactment of the Supreme Administrative Court Act $t^{331}$. An administrative court has been created with the specific task of "dispensing justice by judicial control of public administration" ${ }^{332}$. The court will be based in Warsaw and regional offices will be created. The act sets out the organisation of the court, the powers of the President, the role of the Council of the Court, and related matters. The result is a complex and sophisticated judicial body with extensive powers to review administrative action. It should be noted that the Supreme Administrative Court is a single instance court, which means that there is no appeal from the judge at first instance to a higher court.

The only recourse from a decision of the Supreme Administrative Court is a procedure known as extraordinary review which is brought before the Supreme Court of Cassation. This procedure cannot be invoked by a private citizen or party, but depends on the intervention of the Minister of Justice, the Commissioner for Citizens' Rights, or the Prosecutor. The citizen who feels aggrieved by a decision of the Supreme Administrative Court may write to or petition any one of these bodies, which may then decide to pursue the matter in the Supreme Court of Cassation. This is, however, truly an extraordinary procedure which is reserved for gross infringement of legality by the Supreme Administrative Court and is not invoked more than a few times in a year. Where it is invoked, the procedure is governed by the Civil Procedure Code. The present position is clearly unsatisfactory and moves are afoot to create an appeal within the Supreme Administrative Court itself. This would mean dividing the court into two levels, first and second instance; it would also largely remove the need for extraordinary review.

326 Small Constitution, Article 33a.

327 Article 33a.5.

328 Article 33b.

329 Administrative Procedure Act, Article 111.

330 Resolutions arising in the course of an administrative process should include information as to any forms of appeal that are open, including review by the administrative court, Article 124.

331 Act No. 74 of 1995.

332 Article 1. 
The powers and duties of the Supreme Administrative Court are broadly of two kinds: one is to review specific administrative actions for legality, the other is to notify the President of the Council of Ministers of problems connected with the functioning of the public administration ${ }^{333}$. The second of these functions is not expressed in any detail, but the idea is that this court should report general problems of administration which come to its notice through the exercise of review in specific cases. The Court is also under a duty to report to superior administrative authorities serious violations of the law, the circumstances incidental to those violations, and any failure to implement the court's judgement on the part of the primary authority ${ }^{334}$. This second power is rarely used.

By far the most important part of the Supreme Administrative Court's powers is to review specific cases of administrative action. Any person who has a legal interest in an action may seek review in this court, although the concept of a legal interest is not elucidated ${ }^{335}$. Action for review may also be started by the Prosecutor, the Commissioner for Citizens' Rights, or a social organisation, that is, an interest group. Generally, internal appeal procedures provided for under the Administrative Procedure Act or other laws must be exhausted before review may be sought, except in the case of the Commissioner for Citizens' Rights $^{336}$. Time limits for mounting an action in the court are set out in the act. Once an action has been started, the authority whose actions are in issue is asked to reply to the allegations within a certain time ${ }^{337}$. Failure by the authority to respond means that the court may proceed on the basis of the law and facts set out in the complaint ${ }^{338}$.

The scope of the court's jurisdiction in reviewing administrative action is wide; it includes decisions, intermediate actions or steps taken in the course of a decision, act or activities other than decisions, and various actions of local authorities. ${ }^{339}$ Its jurisdiction also extends to the failure of an authority to act ${ }^{340}$. It should be noted that the range of administrative action within the court's jurisdiction is substantially wider than that covered by the Administrative Procedure Act; for while the latter is confined to decisions, the court's jurisdiction under the Supreme Administrative Court Act extend to a wide range of other forms of action. The power of review also includes examination of some categories of normative actions, that is, the making of administrative rules and regulations of different kinds. Its powers in this respect, however, are confined to certain kinds of normative acts ${ }^{341}$. The jurisdiction of the court is excluded where special courts are created to exercise review in specific areas of administration ${ }^{342}$.

The criterion of review of administrative action by the Supreme Administrative Court is conformity with the law ${ }^{343}$. Reference is made to a number of grounds of invalidity in Article 156 of the Administrative Procedure Code; that section specifies some of the grounds on which a superior administrative authority may declare primary decisions to be invalid on an internal appeal. The grounds stated there are, however, of a technical nature and offer little guidance on the wider concept of legality. The Polish courts

\section{$333 \quad$ Article 14.}

334 Article 32.

335 Article 33.2.

336 Article 34.

337 Article 36.

338 Article 39.

339 Article 16.

$340 \quad$ Article 17.

341 Article 16.5.

$342 \quad$ Article 19.

343 Article 21. 
themselves, in the course of exercising review of administrative action, are developing a rich array of principles under the general principle of legality. The Constitutional Court, the Supreme Court of Cassation and the Supreme Administrative Court have all, in recent years, contributed to this jurisprudence; it has also been enhanced by opinions issued by the Commissioner for Citizens' Rights.

On finding illegality, the Supreme Administrative Court has power to reverse the decision or resolution, or to declare its invalidity or non-conformity with the law. Various other rather specific powers to deal with special situations are expressed in the Supreme Administrative Court Act; but special note should be made of the Supreme Administrative Court's power to require an authority to perform an act or make a decision where it has refused to do $\mathrm{so}^{344}$. The court must give reasons for its decision and convey the reasons to the parties involved $^{345}$.

The Poles take considerable pride in their administrative court system and in the way that judicial review has grown and prospered since its tentative introduction in 1980. The new Supreme Administrative Court has an extensive jurisdiction which embraces most significant aspects of administrative activity. It is claimed that the judges in the administrative courts are well-trained and proud of their independence of mind and judicial powers. This general impression was certainly borne-out in my discussions, albeit rather limited, with administrative court judges. One jurisdictional point to note, however, is that not all normative acts are subject to review. The main negative feature of the administrative court system is the absence of appeals from first instance decisions, but proposals for remedying the situation are underway.

It appears that the numbers of cases brought to the Supreme Administrative Court is growing steadily each year, the figure in 1995 being around 40000 . The popularity of the court does bring its own problems, the most concerning of which is the increasing delay in dealing with cases. It was reported to me that at the beginning of 1995, about 20000 cases were left over from the previous year. Legal representation, or the widespread lack thereof, is another cause for concern. Most cases brought before the court are without legal representation. The general lack of legal representation puts additional burden on the courts and undoubtedly is not in the best interest of appellants. The shortage of lawyers working in the field of public law is as acute in Poland as elsewhere in the region.

\section{3. $\quad$ Appeal on the Merits}

The only form of recourse on the merits is an administrative appeal brought under the Administrative Procedure Act which may deal with substantive issues of evidence and facts, and judgements based on those facts, as well as with questions of $\mathrm{law}^{346}$. No general provision exists in Poland for an appeal on the merits of an administrative action to a court or court-like body outside and independent of the administration. Between internal administrative appeals and judicial review for legality, there is no intermediate stage.

$344 \quad$ Article 26.

345 Article 54.

346 Article 138. 


\subsection{The Prosecutor}

The office of the Prosecutor is preserved under Article 64 of the Constitution ${ }^{347}$. In addition to his role in the criminal sphere, the Prosecutor's function is to safeguard observance of the law by all parties including administrative authorities. The nature of the role is explained further in the Administrative Procedure Act under which the Prosecutor is given power to request an authority to take action to eliminate a breach of the law ${ }^{348}$. The Prosecutor also has power to lodge an objection against the decision of an administrative authority itself which is in violation of the law ${ }^{349}$. The authority is then required to reconsider its decision and to notify the parties to that effect ${ }^{350}$.

It was noted above that, in addition to the powers of his office under the Administrative Procedure Act, the Prosecutor has standing to seek judicial review of an administrative action before the Supreme Administrative Court ${ }^{351}$. The Prosecutor may also initiate extraordinary review before the Supreme Court of Cassation of a decision of the Supreme Administrative Court. In Poland, during the communist period, the Prosecutor's strictly legal role to ensure legality of administrative action was enmeshed with a more political role which was exercised more in the interests of the state than the citizen. It is understandable that for that reason alone the Prosecutor's role should be reduced in the new legal order.

The tainted character of the office is not, however, the only reason for reducing its powers; the Prosecutor's extensive functions in protecting legality were especially important when no other mechanisms existed to perform that role. With the growth of judicial review and the creation of independent administrative courts, the need for the Prosecutor diminished. The assumption now is that the party aggrieved by an administrative action will protect its own rights and, where it considers such action appropriate, will appeal to the Supreme Administrative Court. The creation of the Commissioner for Citizens' Rights was another blow to the Prosecutor, since part of both its formal and informal activities are now performed by the Commissioner. Indeed, it appears that in practice the Prosecutor does not regularly exercise the powers conferred on it by the Administrative Procedure Act to supervise issues of legality. It remains true, however, that in the small local communities of a vast country, the office of the Prosecutor is still relied on to serve a kind of general ombudsman's role.

\subsection{Ombudsman: The Commissioner for Citizens' Rights}

The office of Commissioner for Citizens' Rights was created in Poland in 1987, two years before the major upheaval marking the end of the communist system and the beginning of the democratic period. The first Commissioner, Professor Ewa Letowska, was a woman of remarkable ability who gave the office an independence and stature beyond that expected. She was able to use to effect the extensive powers conferred by the Law on the Protection of Citizens' Rights $^{352}$. The reasons for the creation of office at that time are not entirely clear, but it seems that the government was attempting to soften rising social tensions by creating an institution which appeared liberal and democratic, while "counting more on its decorative qualities than on its authentically functioning in a way that would be in accordance with the principles of a

347 The Prosecutor is subordinate to the Minister of Justice who holds the office of Prosecutor General: Constitution, Article 64.

$348 \quad$ Article 182.

349 Article 184.

350 Article 186.

351 Article 33.

$352 \quad$ Act No. 109 of 1987. 
real democracy"353. The expectations of the government were apparently confounded, and the office of Commissioner assumed considerable importance in the Polish legal system, an importance which has steadily grown in subsequent years.

According to the Small Constitution of 1992, Poland is a state which "implements principles of social justice" ${ }^{\prime 354}$. The Law on the Protection of Citizens' Rights ${ }^{355}$ states that the Commissioner for Citizens' Rights is obligated to investigate not only whether there has been a violation of the law by an administrative authority, but also whether there has been a violation of principles of community life or social justice. This principle was later given constitutional expression in the Small Constitution of 1992. The Commissioner is appointed by the Sejm and serves for four years. The office is independent of other state bodies and of the government; the Commissioner is responsible to the Sejm. An investigation by the Commissioner may be triggered by the application of a citizen, a social organisation, or a local government; it may also be at the Commissioner's own initiative ${ }^{356}$. The procedures for initiating an action are informal and it is enough that the general subject matter of the complaint be stated.

Once an investigation has been launched, the Commissioner has wide powers to demand an explanation, and the production of documents and information, including the agency's files ${ }^{357}$. An expert may be called in to assist and an audit of the authority may be ordered. The agency or other institution subject to the investigation is obligated to co-operate with and assist the Commissioner; it must provide information, explain its actions, and comment on the Commissioner's appraisal of the situation ${ }^{358}$. At the end of the investigation, the Commissioner is required to specify the course of action which should be taken by the authority to remedy the situation; this may include advice as to how the case may be settled, the demand that a prosecution be brought, or the request that an appeal or review of the action be initiated in the courts $^{359}$. If the primary authority disagrees with or does not comply with the Commissioner's proposals, the matter should be referred to the superior administrative authority for action.

In addition to these extensive powers in specific cases, the Commissioner's office may act of its own initiative and may conduct a more general inquiry. It has general authority to recommend to administrative bodies measures for the better protection of rights and liberties ${ }^{360}$. This may extend to proposals for legislation and it might seek to influence rulings by the Constitutional Court and the Supreme Court. An annual report is made to the Sejm on the activities of the Commissioner, including comments on the level of compliance with constitutional rights and freedom by administrative and other bodies.

It can be seen from this brief analysis that the Commissioner has extensive powers to investigate the actions of administrative authorities in relation to rights and freedoms. What happens if an authority does not accept his proposals is not entirely clear in the act, but the onus appears to be on the superior authority ultimately to insist on compliance. This is not unusual, since in most jurisdictions the authority of the ombudsman depends more on his capacity to reason with and persuade the administration than any threat of legal sanctions.

353 T. Zielinski, The Ombudsman: Possibilities and Delimitations for Action (1994, Warsaw), p. 35.

354 Article 1.

355 Final text Dz.U. 1991, No. 109, Position 471, Article 3.

356 Article 9.

357 Article 13.

358 Article 17.

$359 \quad$ Articles 14 and 15.

360 Article 16. 
It is important to note that the Commissioner's investigation is not confined to breaches of the law in a strict sense but extends to a much wider sense of good administration; this wider jurisdiction is made clear in the reference to principles of community life and social justice. This wider jurisdiction of the Commissioner has been taken very seriously and the concern for those general principles is reflected in its opinions and recommendations. The volume of complaints received by the Commissioner's office suggest that it is well-known to the Polish people and held in high regard. According to the Commissioner's office, more than 30000 complaints were received in 1994 and an additional 50000 letters which did not amount to complaints. About one-quarter of the complaints received raise substantive issues and are fully investigated.

The Commissioner's powers are educative and persuasive, rather than coercive. It appears that administrative agencies are generally co-operative and some members of the office felt that the educative effort of its work on the administration was good, although no systematic evidence is available on this point. Unlike the Hungarian equivalent, the Polish Commissioner has local offices and, as a result, seems to be more visible and approachable to the average citizen. The Commissioner's office makes considerable efforts to publicise its work through the media. At the same time, these are some shortcomings. The Commissioner has expressed a certain frustration at the lack of adequate state finances to meet the recommendations of his office. The very limited resources of the office itself has resulted in delays in managing letters and complaints. It may be noted, finally that the main areas of complaint are employment and social insurance, the administration of justice, and economic issues, such as tax, customs, banking, and consumer rights.

\subsection{Inspectorates, Commissions, and Forms of Special Supervision}

The two special bodies created by the Constitution which potentially have a supervisory role over the administration are the Tribunal of State and the Supreme Chamber of Control ${ }^{361}$. The Tribunal of State has the duty to adjudicate on the responsibility for breaches of the law and the Constitution by persons holding high office. The details of this jurisdiction are to be spelt out in a separate law. Some of the procedures for bringing a person before the tribunal are stated in the Standing Orders of the Sedum ${ }^{362}$.

The Supreme Chamber of Control has power to regulate the economic, financial, and organisational-administrative activities of administrative authorities and other public bodies. The grounds on which the control is to be exercised are legality, economic efficiency, efficacy and integrity ${ }^{363}$. The chamber is subordinate to the Sedum and again it is expected that a detailed statement of its powers and procedures will be set out in a separate law. It is also expected that the chamber, which serves the function of a national audit office, will become an important form of administrative supervision within its defined area.

\subsection{Parliamentary Supervision}

The Polish parliament consists of two chambers, the Sejm and the Senate. Both chambers may debate issues in the usual way, although the final say on proposed laws lies with the $\operatorname{Sejm}^{364}$. The detailed rules

361

362

363

364

Articles $33 \mathrm{~b}$ and 34.

Constitution of 1992 with amendments, Standing orders 68ff.

Constitution, Articles 34.1.

Constitution, Article 17. 
and procedures of the Sejm are laid down in the Standing Orders of the Sejm. The basic principle is that the parliament should function both as legislator and as a supervisor of government and administration.

Provision is made in the Constitution for the creation of a committee system of the $\operatorname{Sejm}^{365}$. The functions of the parliamentary committees are: (i) the consideration and preparation of matters under deliberation by the Sejm, (ii) the expression of opinions on matters referred to them by the Sejm, and (iii) the supervision of the institutions of state and local government ${ }^{366}$. Provision is made for the appointment of 24 such committees. The committees are expected to play a major role in the examination of draft bills which must be submitted to them ${ }^{367}$. The Constitutional Accountability Committee may become engaged in proceedings to bring senior officials to account before the Tribunal of State ${ }^{368}$.

The supervisory role of committees is stated in detail in the Standing Orders. They should consider reports about the activities of the administration, analyse their activities, and consider the implementation of acts and resolutions of the Sejm. Ministers and other senior officials may be called to appear before a committee, and they may be required to prepare reports and disclose information ${ }^{369}$. Committees may themselves conduct investigations into certain administrative matters and may prepare reports and recommendations addressed to the Sejm and to other authorities such as the Council of Ministers ${ }^{370}$.

How well the committees system is working in practice was difficult to gauge in the sort time available for this study. Many of the committees have only recently began work and it seems that their main energies are devoted to the legislative aspects of their tasks rather than supervision of the administration. Since the committees are constituted by members of parliament, the informal networks and loyalties endemic in the Sejm generally are reflected in the committee system. According to one body of opinion, this hampers the committees in being independently minded and more effective. However, a more detailed study of the Committee system needs to be made for any firm conclusions to be drawn.

\subsection{Conclusions and Matters for Consideration}

The practice of judicial review of administration and the investigative role of the Commissioner for Citizens' Rights are now well established in Poland and appear to be working well, although any firm conclusions on the last point would require fuller inquiry than has been possible for this report. Certainly at the legal and institutional level, the Poles have reason to be satisfied with the progress that has been made in these two forms of supervision. The new law on judicial review of administrative action significantly increased the range of acts and decisions over which judicial supervision may be exercised. The Supreme Administrative Court has established a sound reputation and standing, and its judges are said to be of good professional repute. The absence of an appeal procedure within the administrative court system is a drawback, but that may soon be remedied. The inadequate supply of legal representation is another problem, but that is not so easily solved.

The Commissioner for Citizens' Rights has clearly established itself after nearly 10 years of operation as an independent, trustworthy, and effective post. It seems to be regarded as a good symbol of the new

$\begin{array}{ll}365 & \text { Article } 10 . \\ 366 & \text { Standing Order } 18 . \\ 367 & \text { Standing Order } 37 f f . \\ 368 & \text { Standing Order 68ff. } \\ 369 & \text { Standing Order 79. } \\ 370 & \text { Standing Order } 85 .\end{array}$


order and, in the hands of able and visionary Commissioners, it has won respect from officials and citizens alike. It has a wide jurisdiction, some might say too wide, going well beyond strict legality. It can venture into fairly fundamental social issues and, again, appears to be effective in its endeavours. The main drawback is lack of adequate resources for the enormous tasks in hand.

Other forms of supervision of the administration are more limited and patchy. There are no appeal procedures to bodies outside the administration on matters of substance. That is an issue which ought to be addressed. The role of the Prosecutor in the public law sphere seems to be diminishing, but largely because its previous functions are now served by the administrative court and the Commissioner for Citizens' Rights. A further study is required of other forms of inspectorates and special commissions, such as the Audit Office. And finally, the institutional structure of the Sejm and its system of committees has laid the groundwork for developing effective mechanisms of supervision of the administration, but these need to grow through experience and regular self-scrutiny.

In the light of these remarks, the specific matters which ought to be considered are as follows:

i. while important developments have taken place in judicial supervision of administrative action, the lack of an appeal structure within the Supreme Administrative Court is a shortcoming;

ii. the training of administrative judges, especially at the lower instances, may need to be strengthened;

iii. the scope of jurisdiction of the Commissioner for Citizens' Rights should be reviewed to see whether it may need to be broadened or narrowed;

iv. the relationship between internal administrative appeals and appeals to external bodies should be reviewed;

v. attention should be given to the issue of appeals to external and independent bodies on the merits and substance;

vi. the role of the Prosecutor is now less clear, especially with the expansion of judicial review and the wide recourse to the Ombudsman; and

vii. closer study is required of the role of inspectorates and other special supervisory bodies to determine whether their powers are adequate and whether their coverage of administrative activities is satisfactory.

\section{Bulgaria}

\subsection{Overview}

The Bulgarian Constitution of 1991 contains provision for the judicial review of administrative actions, including normative acts as well as individualised actions. Some of these areas are dealt with in more detail in the Administrative Procedure Act, but there is a need for further general laws specifying the procedures of judicial review as a whole. (Some provision is currently contained in the Civil Procedure Act.) The Constitution also requires the creation of a Supreme Administrative Court, although this has not 
yet been implemented. The Prosecutor continues to have a role in supervising the legality of administrative action, although that role has been reduced in recent years ${ }^{371}$.

Other forms of administrative supervision are rather underdeveloped. There are no procedures for appeals to be brought on the merits of administrative action to a court or other judicial body, the only appeals on the merits being those within the administrative system itself ${ }^{372}$. There are no plans to create an Ombudsman of either a general or particular kind, and no general provision exists for other forms of investigation of individual complaints against the administration. The parliamentary scrutiny of administration has considerable potential, especially through the committee system, which is now established, but it is too early to tell whether that potential is being realised ${ }^{373}$.

\subsection{Judicial Review of Administrative Action}

The Constitution makes provision for the judicial supervision of the administration. First a Constitutional Court is created whose duties, amongst others, are to provide binding interpretations of the Constitution and to rule on the constitutionality of laws of the National Assembly and acts of the President ${ }^{374}$. Since the provisions of the Constitution apply directly ${ }^{375}$, the jurisdiction of the Constitutional Court may, presumably, be invoked directly by a person, organisation, or official authority wishing to challenge, say, the constitutionality of an act of the President. The court's jurisdiction could also be invoked if, in the course of judicial review of an administrative action, an important point of interpretation of the Constitution should arise.

Of greater significance for judicial review of administrative action is the constitutional principle that the courts shall supervise the legality of acts and actions of administrative authorities ${ }^{376}$. The difference between an act and an action may be lost in translation, but the jurisdiction of the court is cast in the widest terms and would appear to cover all actions of an administrative nature, including normative acts as well as individualised acts. This interpretation is reinforced by the following section which declares that citizens and other legal entities are free to contest any administrative actions affecting them, except those expressly excluded by law.

According to the Constitution, review is to be conducted by a Supreme Administrative Court ${ }^{377}$, which is charged with exercising supreme judicial oversight as to the precise and equal application of the law in administrative $\operatorname{areas}^{378}$. The court is also expressly required to rule on the legality of acts of the Council of Ministers, individual ministers, and other acts performed under a law ${ }^{379}$. The Supreme Administrative Court has not yet been created and in the meantime the power to review administrative action is exercised by the Supreme Court. News has been received of the appointment of the first President of the proposed

371 A more recent law, which includes important provisions on the Prosecutor, The Judicial System Act (Act No. 59 of 1994), has been enacted.

372 These are discussed in Part I of this report.

373 New rules regulating the procedures of the National Assembly were adopted in 1995.

$374 \quad$ Article 149.

375 Article 5.2.

376 Article 120.1.

377 Article 119.

378 Article 125.

379 Article 125. 
Supreme Administrative Court, but no definite arrangements have yet been made for bringing the court into operation.

Taken as a whole, these provisions of the Constitution appear to indicate clearly that the scope of review of administrative actions is to be construed as broadly as possible to apply to all authorities, from the Council of Ministers down, and to cover administrative actions of all kinds, whether individualised or general, whether internal to the administration or external. The only two exceptions are, first, matters excluded by law and, second, the actions of the President. This broad interpretation of the scope of review has been endorsed recently by a decision of the Constitutional Court in an action brought by the Prosecutor $^{380}$. In that case, the Constitutional Court ruled that all administrative actions are open to review, subject to the two exceptions noted, the only condition being that the rights or interests of the party seeking review must be affected. This last requirement would presumably not apply when the action was brought by the Prosecutor ${ }^{381}$.

While the constitutional principles are sound, the application of those principles in practice is not so straightforward. The only general law in operation at present, specifying the procedures for bringing an action for review, is the Administrative Procedure Act of 1975 as amended. The Administrative Procedure Act provides for appeals from administrative acts to the courts on the grounds of legality ${ }^{382}$. This form of review lies in general to the district courts, although challenges to the acts of ministers and various other senior officials should be made in the Supreme Court ${ }^{383}$. The procedures for bringing an action for review are set out in the Administrative Procedure Act; they include matters such as the time limits for bringing an action, the relationship to internal administrative appeals, the need to lodge the application with the authority whose actions are being challenged, and the grounds on which the action may be reviewed. It should be noted in passing that internal administrative appeals need not be exhausted before seeking judicial review. This is the current position following recent amendments to the $\mathrm{act}^{384}$.

The grounds of review of administrative action under the Administrative Procedure Act are as follows. The overriding criterion is the principle of legality which is defined in terms of:

i. competence: did the authority have the legal power to act;

ii. compliance with procedural and substantive laws; and

iii. compatibility with the aims and purposes of the law385. What is added by the third of these is not clear, but perhaps it opens the way to a more exacting consideration of the underlying objectives and whether the authority acted in accordance with them. Review for improper purposes is a well-established ground in many jurisdictions and the present provision may open the way for the Bulgarian courts to develop a similar jurisprudence.

The court cannot review the merits of the decision, but is strictly confined to deciding issues of legality; although here as elsewhere, drawing the line between legality and merits is a matter for the courts. The Administrative Procedure Act goes on to say that, where illegality is made out and the matter is not one

380 Decision 21, 26.12.1995, Official Gazette 99, 1995.

381 Article 127.

382 Article 33.

383 Article 36.

384 Article 35.2.

385 Article 41. 
dependent on the discretion of the authority, the court may decide the merits ${ }^{386}$. This is an exceptional situation and arises only where the remedying of the illegality points clearly to a particular substantive outcome; the court may then determine that outcome without reference back to the primary authority, as it would be required to do in the normal course.

It can be seen that the scope of review under the Administrative Procedure Act is narrower than that envisaged in the Constitution. The scope of review under the act is confined to administrative acts which are defined as individual administrative acts and do not include normative acts of general application ${ }^{387}$. Indeed, not all individualised acts are covered by the Act since acts of the President and the Council of Ministers are excluded ${ }^{388}$. Other categories of acts also excluded are those relating to the planning of socio-economic development and those concerning the internal affairs of an administrative body ${ }^{389}$. After some years of confusion and uncertainty, it is now clear, as noted above, that acts excluded or not covered by the Administrative Procedure Act are, nevertheless, subject to judicial review under the Constitution, although no procedures for bringing judicial review under the Constitution have yet been laid down.

The position has been alleviated to some degree by the passing of the Judicial System Act in $1994^{390}$. This law provides for the creation of the Supreme Administrative Court and states that the court shall exercise control over the legality of the acts and decisions of administrative authorities. In later sections, the Supreme Administrative Court is given the final authority on the accurate and proper application of the law, and on the legality of regulations ${ }^{391}$. The law goes on to declare that citizens and legal persons may contest before the court any administrative act which affects their rights and legal interests. The only qualification to this principle is that specific exceptions may be made by law $^{392}$. This is a curious provision. The courts may review all acts and measures of administrative bodies, and to that principle no exceptions are allowed. Citizens and legal persons may challenge acts affecting them, but exceptions can be made.

The two principles are not congruent, since the rights of citizens and legal persons are limited to challenging acts not decisions, and even some acts may be put beyond challenge by such parties by specific legal provision. Why the rights of citizens and legal persons should be limited in this way is not clear. Indeed, the question should be raised whether the restriction to acts and the exclusion of measures is compatible with Article 120 of the Constitution which provides that citizens and legal persons may contest any administrative act affecting them, unless excluded by law. The law on this point needs to be clarified.

It should be noted that, within the Supreme Administrative Court, there will be two levels of review first instance and cassation — although some officials suggest the need for a third instance.

The Judicial System Act goes on to specify in detail the nature and composition of the Supreme Administrative Court. I shall not examine these provisions in detail, except to note that they create a sound and satisfactory administrative court system. The procedures governing the workings of the Supreme Administrative Court will be contained in a new procedural law which is presently under

386

387

388

389

390

391

392

Article 42.2.

Supplementary Provisions 1.

Article 3.

Article 3.

Act No. 59 of 1994.

Article 34.5: but compare Article 91.1.

Article 9. 
discussion. This new law will make important amendments to the Administrative Procedure Act; the new law is not yet available in draft.

The tradition of judicial supervision of administration in Bulgaria stretches back to the beginning of the century when Administrative Courts, broadly based on the French model, were established. They were abolished with the adoption of the 1947 Constitution, which terminated judicial supervision of the administration. Since the revival of judicial review, which began in the later years of communism and expanded in the democratic period, it has been exercised by a special division of the Supreme Court. This has not been entirely satisfactory and the use of judicial review by citizens is still fairly limited. The new Supreme Administrative Court will be a welcome development, but it will take some time to become established as an accessible and effective form of administrative scrutiny. Two particular problems will be the shortage of judges with experience in administrative law, and the scarcity of lawyers willing to practice in this field.

\subsection{The Prosecutor}

The office of the Prosecutor is retained in the new Bulgarian Constitution and the Prosecutor's role continues to be of importance in the administrative law context ${ }^{393}$. The public law duties of the office are: first to take action to have rescinded illegitimate acts, including those of administrative authorities; and second, to take part in administrative cases when required by law. One law so requiring the Prosecutor to participate is the Administrative Procedure Act which states that the Prosecutor shall file protests in the courts against administrative acts which he considers to be in breach of the law ${ }^{394}$. It seems that the Prosecutor is also expected to participate in all cases of administrative review under the Administrative Procedure Act, even where the action is brought by another party ${ }^{395}$. In practice, however, the Prosecutor does not often intervene. The Prosecutor also has a role in interpreting normative acts upon a request being made by a person ${ }^{396}$.

The Prosecutor proceeds by first bringing the alleged illegality to the attention of the authority responsible for it. The authority must consider the Prosecutor's protest within a fixed time and decide what to do about it. If nothing is done to remedy the illegality, the Prosecutor shall bring it to the attention of the superior administrative authority; the Prosecutor may also lodge a protest before the court under the Administrative Procedure Act, as noted above. The one major limitation is that the Prosecutor's interest is confined to the legality of administrative actions, not their merits.

The main law governing the functions of the Prosecutor in Bulgaria is now the Judicial System Act ${ }^{397}$. This recently enacted law provides for the continuation of the office and specifies its organisation and powers, a central feature being that it is independent of both government and the courts. The primary responsibility of the Prosecutor's office in the public law sphere is to supervise the legality of administrative action $^{398}$. In conducting that supervision, the Prosecutor shall take action to rescind illegal

\section{$393 \quad$ Article 127.}

394 Article 35.2.

$395 \quad$ Article 41.1.

396 Law on Normative Acts (1973) Article 47.

397 Law No. 59 of 1994. The previous Law on The Prosecutor's Office (Law No. 57 of 1980) has been repealed, although the regulations made under it are still in force.

$398 \quad$ Article 114.1. 
acts and to restore rights arbitrarily violated ${ }^{399}$; the office shall also participate in administrative cases where authorised by law ${ }^{400}$. In discharging those functions, the Prosecutor's office has extensive powers to call for the production of materials, to conduct inspections, to summon witnesses, and to lodge protests to administrative bodies about specific actions taken by them ${ }^{401}$.

Where the Prosecutor's office considers that an administrative action is illegal, it may request the repeal of the action according to procedures laid down by law ${ }^{402}$. The Prosecutor may stop the implementation of an action until the protest made by his office to the administrative authority has been considered. In the conduct of its powers and duties, the Prosecutor's office may expect the co-operation of administrative authorities $^{403}$.

It can be seen from this brief account that the office of the Prosecutor continues in modern Bulgaria as a form of supervision of administrative legality. The model of the Prosecutor which prevailed during the years of communist rule, a model itself borrowed form the former Soviet Union, has been replaced by an office which is independent of the other institutions of law and government and which has a greatly reduced role. In Bulgaria, as in other countries of the region, the increase in the availability and scope of judicial review has meant a reduction in the importance of the Prosecutor's office. Although its role in the supervision of administration is still significant, in practice the Prosecutor's office tends to intervene only in cases of great public interest and importance, and in cases where no judicial remedies are available.

Although I did not have access to official figures, I was told in interviews with officials that the Prosecutor's office becomes involved in barely a handful of cases each year. It was suggested that these are most likely to be with respect to normative acts - regulations, decrees, etc. - rather than individualised actions. Indeed, the opinion was expressed to me on several occasions that intervention by the Prosecutor in individualised actions would not be considered appropriate, except in rare circumstances.

\section{4. $\quad$ Appeal on the Merits}

Internal appeals from the primary administrative authority to a superior body under the Administrative Procedure Act may deal with the merits of the case. Where there is no internal administrative appeal, there may be provision for an appeal on the merits to a court. Whether there is, and the precise nature of the appeal, depends on specific laws. Judicial review by the courts is generally restricted to legality. No general laws exist for an appeal on the merits to a court or court-like body and there are no plans to introduce such a scheme.

\subsection{Ombudsmen and other Complaints Procedures}

The Bulgarian Constitution does not provide for the office of Ombudsman whether of a general or special kind. This is a departure from the usual pattern since, in each of the other countries studied here, some form of Ombudsman has been created or is being planned. In some of those countries where the idea of an Ombudsman with general jurisdiction has not been adopted, it is thought important that there should at

Article 118.3.

$400 \quad$ Article 118.4.

$401 \quad$ Article 119.

402 Article 119.5.

403 Article 119.3. 
least be an Ombudsman for the protection of constitutional rights. Both Hungary and Poland have taken that approach.

The constitutional right of citizens to lodge complaints, proposals, and petitions with state and administrative bodies opens the way for the creation of more extensive complaints procedures, including Ombudsmen $^{404}$. This right, which is commonly found in the constitutions of the region, may be given effect through informal complaints procedures; but in Bulgaria, to date no action has been taken on the basis of the provision to create formal procedures and mechanisms.

\subsection{Parliamentary Supervision}

The Parliament of Bulgaria is created by the Constitution ${ }^{405}$. It is called the National Assembly and has the usual legislative powers of a parliament. The National Assembly is democratically elected and is conducted according to rules and procedures stated in the Rules of Organisation and Procedure of the National Assembly (referred to as the Rules of Procedure) ) $^{406}$. As a supervisory body with respect to the administration, the National Assembly may debate issues in the usual way, and provision is made in the Constitution for members to address questions to the Council of Ministers and to individual ministers who are obliged to answer them ${ }^{407}$. The supervisory role of the National Assembly is spelt out in detail in the Rules of Procedure $e^{408}$.

The Constitution also provides for the creation of parliamentary committees which may be permanent or ad $\operatorname{hoc}^{409}$. The permanent committees are meant to assist the National Assembly, while the ad hoc committees may be elected to conduct inquiries and investigations. Both officials and citizens may be summoned to appear before a committee and be required to give evidence and answer questions ${ }^{410}$. The rules governing the working of the committees are stated in the Rules of Procedure.

The creation of up to twenty permanent committees is envisaged. Membership is restricted to members of the National Assembly and reflects proportionately the parties and factions within the National Assembly. Standing committees may form sub-committees and working groups.

The functions of the standing committees include examining draft bills, resolutions, etc. and providing opinions on such matters as the National Assembly may request ${ }^{411}$. Precise duties of supervision of the administration are not laid down, but it may be expected that a scrutinising and supervisory role is implicit in their general duties. The appointment and powers of ad hoc or select committees (the terms being interchangeable) are left very much to the National Assembly to determine. The Rules of Procedure follow the Constitution in providing that such committees may be appointed to investigate particular

404

405

406

407

408

409

410

411

Constitution, Article 45.

Constitution, Chapter 3.

State Gazette No. 13/1995.

Constitution, Article 90.

Rules of Procedure, Chapter 3.

Rules of Procedure, Article 79.

A similar provision is contained in article 24.2 of the Rules of Procedure.

Constitution, Article 24. 
matters and to conduct inquiries ${ }^{412}$. It is easy to see that they might be put to good use in enquiring into important issues of administration.

Although the committees of the National Assembly have the powers and the potential to become a significant means of supervision of the administration, they have not yet reached that point. Their primary function in practice is in the legislative process, rather than in scrutinising and monitoring the implementation of legislation by the administration. It may be, indeed, that the supervisory function of the committee system will always be regarded as of secondary importance. This is not to suggest that the committees are inactive in this secondary function. Some committees, such as the Committee on National Security, are active in exercising a supervisory role. A variety of ad hoc committees have been created for particular purposes. Around twenty five were said to have been created during the life of the last parliament to inquire into a range of matters, including the supply of water to Sofia and the operation of a large oil refinery. It seems, therefore that the committee system has a sound legal and organisational basis which may develop in future years to become an effective form of administrative supervision.

\subsection{Conclusions and Matters for Consideration}

Following the adoption of its new Constitution in 1991, Bulgaria has created the framework for a modern and effective system of judicial review of administrative action. Under the Constitution, the principle of judicial review of administrative action, for both normative acts and individualised actions, is expressly stated. However, the full application and development of that principle has been hampered by the delay in enacting a detailed law and in establishing the Supreme Administrative Court. The Judicial System Act of 1994 partly remedies the first defect, while the Supreme Administrative Court is expected to be in operation fairly soon. The creation of the court will be a major step forward, but the need for a comprehensive law governing the substance and procedure of judicial scrutiny remains a pressing need. There are also more practical problems to face, the shortage of experienced judges and interested lawyers being just two of them. One important point to note is that, since 1989, recourse to the courts is available without first exhausting any internal administrative appeals.

Apart from judicial review by the courts, the range of mechanisms in Bulgaria for supervising the administration are severely limited to the point of non-existence. The Prosecutor's office retains certain functions in this regard, but they are not frequently invoked and are marginal in their impact. The Constitution does not provide for the creation of ombudsmen and, within official opinion, there seems to be little support for such offices. It also seems that there are few alternative methods and institutions for receiving and investigating complaints and grievances, despite the constitutional principle entrenching the rights of citizens to express their dissatisfaction. The lack of an adequate range of non-judicial mechanisms of supervision ought to be a matter of concern. The parliamentary system of committees is well-constructed and has potential, but it has not yet become an effective form of administrative supervision.

Following these general comments, the specific points for consideration are the:

i. delay in establishing the Supreme Administrative Court is now a serious hindrance to the development of a sound system of judicial supervision;

ii. grounds on which the court will intervene need clarification and elaboration;

$412 \quad$ Constitution, Article 31.1. 
iii. shortage of properly trained administrative judges and lawyers is a serious impediment to the operation of the administrative court system;

iv. case for creating one or more ombudsmen is quite pressing;

v. role of the Prosecutor in supervising the administration should be reviewed in the light of the increased scope for judicial supervision;

vi. adequacy or otherwise of other institutions and mechanisms of supervision, such as inspectorates and special boards and commissions, should be examined; and

vii. ways of making the committee system of parliament more effective as a means of supervision of the administration ought to be considered.

\section{Estonia}

\subsection{Overview}

In the years since independence from the Soviet Union, Estonia has made progress in devising institutions and mechanisms of administrative supervision. The Supreme Court exercises a general review of the constitutionality of legislative and administrative acts, while a system of administrative courts has been created to review the legality of both subordinate legislation and individual administrative acts. Applications are heard by the administrative court at first instance, with the possibility of an appeal to the circuit courts and, in special cases, to the Supreme Court. The courts are limited, however, to issues of legality and no provision has been made or is intended for appeals on the merits to the courts or similar bodies. However, there do exist in some areas of administration court-like bodies which are authorised to re-examine not just the legal issues but also the merits of the action; a good example is the Appeal Commission of the Patents Office. Actions for review in the courts are normally brought by parties whose interests are affected by administrative action.

The Legal Chancellor, which is a post provided for in the Constitution, has a general duty to ensure that administrative bodies exercise their powers according to law and he or she may take steps to have remedied violations of the law or the Constitution. This power extends only to normative acts and does not include individualised actions. If such steps fail, the Legal Chancellor may take review proceedings in the Supreme Court. The Legal Chancellor may take action on his or her own initiative or respond to complaints from the parties affected. In responding to the complaints of citizens, the Legal Chancellor might be thought to bear some similarity to an Ombudsman, although the former in reality performs a much more limited role.

The office of Ombudsman, whether general or specific, does not yet exist in Estonia, nor is provision made for it in the Constitution. Plans are being discussed for its creation, although at the time of writing, those plans are at an early stage. There does seem, however, a real commitment amongst government and departmental officials to its creation. In the meantime, some of the functions of Ombudsmen in receiving and (to a limited extent) investigating complaints are performed on an informal basis by each of the ministries and by the State Chancellor's Office.

Parliament may exercise the usual forms of supervision of the administration. An extensive system of permanent and ad hoc committees of Parliament is in operation, but their role in scrutinising the administration appears, so far, to be very limited. Internal administrative control of one body over another has recently been introduced by law, but it is too early to say how it will work and what the effects will be. 


\subsection{Judicial Review}

According to the Constitution adopted in 1992, Estonia is a state governed by the Constitution and the ${ } \mathrm{aw}^{413}$. It is also a state based on the separation of powers ${ }^{414}$. Other references are made to the rule of law: everyone has the right to the protection of the state and the $1 \mathrm{aw}^{415}$; and the law shall protect everyone from the arbitrary exercise of power by administrative authorities ${ }^{416}$. Anyone whose rights and freedoms are violated has the right of recourse to the courts ${ }^{417}$. Justice is to be administered solely by the courts, which are to be independent in their activities and which are to administer justice in accordance with the Constitution and the law ${ }^{418}$. It should be noted that, despite these general principles, the Constitution does not include directly the principle of judicial review of administrative action.

Provision is made in the Constitution for the creation of special administrative courts ${ }^{419}$. The courts have been created and are in operation. They are governed by Administrative Courts' Procedure Act ${ }^{420}$. This act sets out the procedures to be followed by the court and specifies the grounds of review of administrative action. Any person with an interest may challenge the individualised actions of an administrative body before the administrative court. It should be noted that this right of challenge does not include normative acts. The matter is heard at first instance by a single judge, followed in some cases by appeal to the Circuit Court which sits as a bench of three judges. Final appeal lies to the Supreme Court, but the leave of the Supreme Court must be obtained and the court has discretion in deciding which cases to accept. It is likely to grant leave only in cases raising issues of public importance. Normally four justices sit in the Supreme Court to hear such matters and it is interesting to note that, in 1995, around 50 cases were brought before the Supreme Court.

Applicants seeking remedies in the Administrative Courts are of course entitled to be legally represented, but in fact have representation in only about half the cases. This seems to be attributable partly to the shortage of lawyers in the country and partly to the low fees paid for legal work under the legal aid scheme. The court has a general duty to get to the truth of the matter and may adopt an inquisitorial approach to cases before it. There is evidence, obtained in interviews, to suggest that the judges of the administrative court encourage informal negotiation between the parties with a view to settlement and in order to avoid the necessity for a full hearing. The one area in which a substantial number of administration cases have been brought relates to the restitution of land. Another part of the courts' time is taken up with jurisdictional disputes as to whether an action is properly brought before the administrative courts or the civil courts.

The Administrative Courts' Procedure Act does not specify in any detail the grounds of review of administrative action, but the principle of legality is the overriding consideration. This is interpreted to mean not only the violation of substantive or procedural laws, but also to include more general principles. For example, failure of the administrative body to provide a hearing to the parties would be a ground of review on the basis of legality. Similarly, the non-disclosure of information or the gross unreasonableness

413 Constitution, Article 3

414 Constitution, Article 4

415 Constitution, Article 12.

416 Constitution, Article 13.

417 Constitution, Article 15.

418 Constitution, Article 146

419 Constitution, Article 148.

$420 \quad$ Law No. 50 of 1994. 
of the decision might well be defects which go to the legality of the decision. A full sense of legality, however, is still being developed by the courts. According to some judges and officials, the principle of proportionality is beginning to develop in Estonian law as a ground of review. Some officials also thought that the Administrative Courts' Procedure Act ought to spell out in more detail the grounds of review, although undoubtedly the Supreme Court will have an active role in developing such grounds in the cases which it agrees to hear.

In addition to the administrative court system, judicial review of legality may in some cases be sought directly in the Supreme Court which has an Administrative Law Chamber. The Supreme Court is responsible for ensuring that the laws and administrative actions are constitutional; an application raising such issues may be made directly to the Supreme Court, although it seems that the jurisdiction of the Supreme Court may be invoked only by the Legal Chancellor or the President of the Republic. The Legal Chancellor, as noted earlier, has a duty under the Constitution to scrutinise the legality of legislative acts to make sure that they comply with the law and the Constitution ${ }^{421}$. The Legal Chancellor, however, has limited resources and, therefore, limited capacity to monitor subordinate law-making. Potential areas of illegality might be brought to the attention of the office by an interested party, or the Legal Chancellor may discover such matters for himself $f^{422}$. Where the Legal Chancellor decides to seek a ruling on the legality of subordinate law, the action is brought directly before the Supreme Court.

While the Administrative Courts' Procedure Act is an important piece of legislation, it does have significant defects. The precise limits of the jurisdiction of the courts pursuant to the act are not clear; as a result, many cases in the courts are about jurisdiction. It has been said that the procedures to be followed by the court are not stated in sufficient detail in the act. The court's powers are limited in relation to remedies. It cannot invalidate the administrative action under review, but can only order that the primary decision-maker change it. Failure to comply with its order may result in a fine but no further action to compel compliance is available. And finally, while the administrative courts are expected to adopt an investigative and inquisitorial approach to cases brought to them, they have very limited resources with which to do so. This may in turn encourage the courts to try to bring the parties to agreement. A shortage of lawyers working in the Administrative Courts adds to these problems.

\subsection{The Legal Chancellor}

The office of the Legal Chancellor is provided for in Article 139 of the Constitution. The Legal Chancellor is an independent official whose function is to monitor the legislative acts of the executive, of local governments, and of other governmental bodies to ensure that they conform to the Constitution and the laws of Estonia. The Legal Chancellor is appointed by Parliament on the recommendation of the President for a term of seven years. The powers of the office created by the Constitution are spelt out in more detail in the Legal Chancellor's Activities Organisation Act ${ }^{423}$.

The office of Legal Chancellor does not exist in other central and eastern European countries. It is an office which existed in Estonia prior to the Soviet period and appears to derive from a similar office in Finland. The office of Legal Chancellor should not be confused with that of Prosecutor although in a number of the countries of the region the office of Prosecutor does perform some of the same functions as the Legal Chancellor. The main difference it seems is that, during the Communist period, the Prosecutor was regarded as a vital organ of central government, and in turn of the Party machine, whereas the Legal

421 Legal Chancellor Activities Organization Act, Articles 2 and 17 (Law No. 26 of 1995).

$422 \quad$ Ibid, Article 12.

423 Law No. 26 of 1995. 
Chancellor is regarded as an independent office which did not exist during the Soviet period and has been revived since. The office of Prosecutor was abolished in Estonia in 1992, but consideration is being given to its revival in a new form.

The Legal Chancellor receives copies of all legislation of general application from all areas of government. If the Legal Chancellor finds legislation to be in conflict with the Constitution or the law, an approach will be made to the authority responsible for the legislation, decree, etc., to request that it be amended accordingly. In carrying out this task of scrutiny, the Legal Chancellor's Office and its advisers have rights of access to documents and other information held by public authorities. If the necessary amendments are not made by the agency from which the law originated within a specified time, the Legal Chancellor may commence an action before the Supreme Court.

The Legal Chancellor reports annually to the Riigikogu (the Estonian Parliament) and may report on specific matters as well. Although the Constitution and the formal law suggest that the Legal Chancellor's powers are confined to legislative acts, in practice it appears that his jurisdiction extends to individualised acts as well. A citizen may apply to the Legal Chancellor to complain about an alleged illegality; the Legal Chancellor should then investigate the complaint and take whatever action is appropriate ${ }^{424}$.

It is difficult to gauge the effectiveness of the office of Legal Chancellor as a form of supervision of the administration. It may receive petitions from citizens about administrative propriety, but its formal powers are limited to supervision of normative acts and it has no jurisdiction with respect to individualised actions. This means that its formal powers are very limited, although, as noted above, there may be some scope for taking action with respect to individualised acts.

\section{4. $\quad$ Appeal to a Court on the Merits of Administrative Actions}

It has been noted above that no general provision exists in Estonian law for appeal from an administrative action to a court or other judicial tribunal on the merits of the case. The proposed Administrative Procedure Act, which should be presented to the Riigikogu during 1997, will make provision for internal administrative appeals, that is, from the primary decision maker to a superior administrative body. No provision is intended for further appeal to an external court or tribunal to consider the merits of the matter. The only external review is on the ground of legality as discussed above. Some experts in the field have expressed the view that the Administrative Court Procedure Act should specify the grounds of review and that the grounds for review should extend beyond legality to substantive issues; that, however, is unlikely to happen. Although there is no general provision for external review of the merits, it was noted earlier that some special jurisdictions do exist in which there is such review. A full study of those was not possible for the purposes of this Report.

\subsection{Ombudsman}

In contrast with a number of other countries of the region, the Estonian Constitution does not provide for the office of Ombudsman. It is now recognised, nevertheless, that an Ombudsman is desirable and plans are afoot for the drafting of an Ombudsman law. Those plans are at a very early stage in the Ministry of Justice and it was not possible to obtain detailed information as to the nature of the office, whether it would be general or special, or what powers it would have. Some officials expressed the view that the combination of the Legal Chancellor's Office and the various supervisory mechanisms created by

$424 \quad$ Legal Chancellor Activities Organization Act, Article 12. 
departments and the State Chancellery were probably sufficient and obviated the need for an Ombudsman. This does not, however, appear to be the prevailing view and other officials are confident that a draft law will be available for submission to Parliament in the near future.

The office of Ombudsman would be clearly much wider than that of Legal Chancellor; whereas the latter is confined to issues of the legality of normative acts, the former would embrace questions of maladministration and improper administrative action in a broad sense, and would be available for individualised administrative acts.

\subsection{Supervision by Administrative Bodies}

In a recent law passed by the Riigikogu, a system of supervision of one administrative body by another was created. Under this law, known as the Government of the Republic Act ${ }^{425}$, duties are placed on the Council of Ministers, individual ministers, Directors of other agencies and authorities, etc. to supervise subordinate administrative authorities in order to ensure that they act according to law, and according to the purposes for which their powers have been granted. The various supervisory bodies are expected to issue detailed legislation as to how their respective supervisory roles will be performed ${ }^{426}$. The powers of supervisory bodies extend to both normative acts and individualised actions. Their powers with respect to both are substantial; they may order that the defects in subordinate legislation or specific actions be remedied; they may suspend the performance of an action or the validity of subordinate legislation; or they may invalidate the legislation or action ${ }^{427}$.

The grounds for supervision are twofold: legality and purposiveness. Legality means conformity with the Constitution, other laws, or regulations and orders of the government, and regulations and orders of a minister ${ }^{428}$. Supervision on the grounds of purposiveness means that the legal instrument or action must be in conformity with state policies as specified by law and implemented by the government or a ministry ${ }^{429}$. Supervision on these grounds also extends to actions which cause unreasonable use of state assets or funds, or which harm national interests in any other way ${ }^{430}$. Any supervisory action taken for lack of purpose must be supported by reasons.

This is an interesting law which creates a framework of administrative supervision not encountered elsewhere in the region. It bears some similarity to internal appeal procedures where an interested party may appeal from a primary decision to a higher supervisory body. It is different, however, in that the new system of administrative supervision is of a more general kind with the supervisory body taking the initiative. It may be thought that administrative supervision of this kind would in practice apply on an informal basis in any country, but what is of particular interest here is to see those informal practices specified in clear legal terms.

Amongst other forms of supervision in Estonia, the State Audit Office warrants mention. It is provided for in the Constitution $^{431}$ and is made responsible for economic control ${ }^{432}$, its main duties being the auditing

$425 \quad$ Law No. 2 of 1996.

426 Article 93.3.

427 Article 93.2.

428 Article 95.2.

429 Article 100.

430 Ibid.

431 Chapter XI. 
of the economic activities of state authorities ${ }^{433}$. The Auditor General, who directs the Audit Office, must report annually to the Riigikogu on the use and preservation of state assets ${ }^{434}$.

It should also be noted that the Constitution guarantees to each person the right to address state agencies, local governments, and their officials with memoranda and petitions ${ }^{435}$. The procedure by which such authorities shall respond are to be provided for by law. No detailed information was available on the extent to which such legal provision has been made or on how the procedures are working in practice.

\subsection{State Chancellery}

The State Chancellery merits special mention for its potential in supervising administration. The State Chancellery is a special section or department within the central government and administration. It is created under the Constitution ${ }^{436}$ and is the revival of a similar pre-war institution in Estonia. The State Secretary, who is the head of the State Chancellery, is appointed by the Prime Minister and has the rights and status of a minister. Amongst the many tasks of the State Chancellery, of special note are its duty to manage the operations of government and to provide support services to the government ${ }^{437}$. It is required to review draft legislation of the government to ensure conformity with the Constitution and the law; it is also required to manage the preparation of draft legislation covering the operation of government and state agencies.

At the administrative level, the State Chancellery has to keep account of the performance of functions assigned to ministers. Although the State Chancellery is still in the early stages of its development, information received from senior officials suggests that it has an important supervisory role over government and administration. At present, this tends to be by reacting to problems that emerge, but the expectation is that the State Chancellery will in time take a more positive and dynamic role in investigating and supervising administrative issues.

\subsection{Parliamentary Supervision}

The Estonian Riigikogu may exercise the usual supervisory powers through its parliamentary procedures. In addition, an extensive system of permanent and special committees of parliament have been created and many of these are in operation ${ }^{438}$. No clear picture has emerged as to how well the committees are working in practice, but according to one senior official the committees tend to react to particular problems rather than exercise a more general supervisory function over the administration.

432

433

434

435

436

437

438
Article 132.

Article 133.

Article 135.

Article 46.

Article 95.

These duties are stated in The Government of the Republic Act, Chapter 5.

See Constitution, Article 71, and the Riigikogu Procedure Act made pursuant to it. 


\subsection{Conclusions and Matters for Consideration}

The main achievements of Estonia in recent years in creating mechanisms of supervision of the administration are the development of judicial review, the creation of a system of parliamentary committees, and, of more limited effects, the revival of the office of Legal Chancellor. Judicial review of administration was created during the later years of the Soviet period, but has become much more readily available in the years since. It still has its shortcomings, however, as noted in the discussion above. These could be remedied by the enactment of an Administrative Procedure Code and by revision of the Administrative Courts' Procedure Act. The practical workings of the administrative courts also need to be examined, especially knowledge about and accessibility to them, the availability of legal advice, and the procedures governing them.

The Parliamentary Committee system is well constructed and has potential as an effective form of supervision of administration, but it is too early yet to tell how it will develop. The Legal Chancellor performs a useful function in ensuring the legality of administrative action, but neither that office nor the State Chancellery are substitutes for a system of ombudsmen. The Audit Office has a vital role in the scrutiny of financial matters, but inspectorates and similar forms of scrutiny need to be developed in a systematic way for the whole administration.

It is recommended that the following specific points be considered:

i. judicial review of administrative action is based on the concept of legality, but it is not clear what the specific grounds of illegality are;

ii. the scope of jurisdiction of the administrative courts needs to be specified with greater clarity;

iii. the capacity of the Supreme Court to hear cases for the review of administrative action, and its relationship to the administrative courts needs to be clarified;

iv. the remedies available to the administrative courts may need to be widened and strengthened;

v. the role of the office of Legal Chancellor in supervising administration should be re-examined and stated more clearly, in particular it should be made clear whether the powers of the office extend to individualised administrative acts as well as normative acts;

vi. the opportunity for introducing a system of appeal on the merits to an independent authority as an extension of or substitute for internal appeals ought to be examined;

vii. the case for creating an ombudsman ought to be considered as a matter of priority;

viii. the supervisory arrangements introduced by the Government of the Republic Act are an interesting development which could be extended further;

ix. the role of supervisory bodies, such as the Audit Office, needs to be reviewed and their adequacy assessed;

x. the potential of the State Chancellery as a form of supervision needs to be further explored; and

xi. finally, the committee system within the Riigikogu, while well provided for, should be examined to see how it could be made more effective in practice. 


\section{Albania}

\subsection{Overview}

Although Albania has not yet adopted a new Constitution, according to a draft rejected in a public referendum in 1994, the public administration would be committed to acting in accordance with the law. Article 39 states that citizens have a right to seek a remedy against an administrative act which infringes rights. The judicial power in Albania is to be exercised by the Supreme Court and other courts established by law $^{439}$. Express provision is made for the creation of specialised courts ${ }^{440}$. Although there is no guarantee that the draft Constitution will be adopted, whatever version finally is adopted it is likely to have provisions along these lines.

Albania is moving slowly in developing institutions of judicial and non-judicial supervision of administration. The Constitutional Court, created in 1992, exercises a general jurisdiction over the legality and constitutionality of administrative norms and actions. The court is mainly concerned with constitutional issues, but it will entertain actions against administrative institutions where the claim is that the institution has made subordinate legislation or performed administrative actions which are in breach of the law. There is some suggestion that actions for review against Ministers or the Council of Ministers should be brought in the Constitutional Court rather than in the Civil Courts.

Apart from the powers of the Constitutional Court, the Court of Cassation also has jurisdiction to review administrative actions for legality. This developing jurisdiction is now supplemented by the creation of administrative divisions within the local District Courts. This reform came into effect on 1 June 1996 and it will mean that any appeal against, or review of, the actions of administrative bodies will be heard at first instance in the Administrative Courts. Appeal will then lie to the Court of Appeal and, in some cases, to the Court of Cassation.

Developments in judicial supervision of the administration are not matched by similar developments in relation to non-judicial bodies. An Ombudsman has not been created and it is not clear how far officials are committed to the idea or are seriously considering it. A number of offices perform some kind of ombudsman role; these include, a special office in the Prime Minister's office, the Parliamentary Commission on Civil Rights (which is a committee of Parliament), and the Constitutional Court itself, which receives complaints from citizens who are not themselves the subject of judicial action. There are also various forms of complaints procedures within particular ministries. However, this fragmented approach is inadequate and it is clear that none of the offices mentioned have adequate powers to investigate and secure suitable outcomes where grievances are substantial. Various inspectorates and other general supervisory bodies exist but, again, not on a systematic basis and with results which are piecemeal and fragmented.

Provision is made for parliamentary supervision through the usual parliamentary forms and a comprehensive system of standing and ad hoc committees is envisaged. Some of these are in operation, but they do not yet provide systematic supervision of administrative institutions. Finally, the Prosecutor's Office, which was powerful under the communist period in protecting the interest of the State and ensuring legality of administrative actions, has been stripped of its public law functions and is confined to its role in the criminal justice process.

440 Draft Constitution, Article 96. 


\subsection{Judicial Review}

Administrative actions may be reviewed by the courts in Albania according to two procedures. The normal procedure is for an action to be brought in the administrative division of the District Courts; the second and less usual course is for review to be sought directly in the Constitutional Court.

The first and main procedure for judicial review has been created by the new Civil Procedure Code which came into effect on 1 June 1996. Article 1 of the code provides for the creation of three special divisions within the District Courts: Administrative, Commercial, and Family. An action can be brought in the administrative division against an administrative act or the refusal to perform an act where the act or refusal is unlawful or the rights or interests of the party are violated ${ }^{441}$.

The jurisdiction of the Administrative Courts extends to administrative acts generally, subject to three exclusions:

i. general normative or legislative acts are outside the scope of review;

ii. administrative acts which, under the Constitution, are subject to the direct jurisdiction of the Constitutional Court; and

iii. administrative acts which are out of time, the time being thirty days from the date of the act or the refusal to $\mathrm{act}^{442}$.

The effect of these provisions is to confer on the courts a wide jurisdiction to review administration, a jurisdiction which is much wider than existed previously. Time limits are also set for the hearing of the appeal and the court must give its reasons $\mathrm{s}^{43}$.

The grounds on which appeals are to be decided are not entirely clear and it may be some time before the courts develop a settled approach. The principle of legality is the governing standard, but just what meaning is given to the principle will emerge over time. It clearly covers direct violation of the law, both as to substance and procedure. Indeed, the procedural aspect is strengthened by the provision in the draft Constitution of 1993 requiring that the principle of due process be respected ${ }^{444}$. Due process or procedural fairness is itself a concept which needs to be given meaning and content, but it clearly extends beyond procedures set down by law and includes more general principles, such as the right to be heard, to have an impartial decision maker, and to be given reasons. The concept of due process is likely to be spelt out in detail in the proposed Administrative Procedure Act (which is likely to be presented to the Albanian People's Assembly in 1997).

Appeals lie from the administrative division of the District Court to the Court of Appeal, with final recourse in special cases to the Court of Cassation. The Court of Cassation was revived in 1992 and is the Supreme Civil Court. Since its creation, it has developed a limited practice of reviewing administrative acts for legality. The legal basis of that jurisdiction is not entirely clear, but apparently derives from the right each person has to test the legality of an action in the courts. That jurisdiction is now conferred under the Civil Procedure Code which confirms the Court of Cassation as the final Court of Appeal in all civil matters, including administrative matters. The existing practice of the Court of Cassation in exercising administrative review is directed to the legality of administrative actions, but a full sense of the

$\begin{array}{ll}441 & \text { Article } 325 . \\ 442 & \text { Article } 326 . \\ 443 & \text { Article } 332 . \\ 444 & \text { Draft Constitution, Article } 30 .\end{array}$


concept is still being developed. The Court of Cassation does not review the facts and merits of a case, but it will consider the rational basis of the action, it will require that relevant matters be taken into account, and it will insist on compliance with the principle of proportionality.

The relationship between the Court of Cassation's role in developing a sense of legality and the first instance administrative courts remains to be worked out once the new appeal procedures come into effect. It may be that the Administrative Court will direct their attention more closely at the facts and merits, while the Court of Cassation, in considering appeals, will confine itself to legality, in the sense of a set of distinct legal principles against which the validity of administrative actions may be judged. The Chief Justice of the Court of Cassation indicated the following as the main principles governing the review of administrative action:

i. breach of the law;

ii. violation of procedures;

iii. failure to take important facts into account; and

iv. a decision of the lower court is illogical or irrational.

The Court of Cassation does not itself evaluate the facts and merits of the administrative action or of the administrative court's decision. In addition to the principles mentioned, the principle of proportionality appears to be gaining ground as a basis for judicial review.

The administrative courts will undoubtedly become the main avenue of judicial recourse for administrative action, but a brief note should be made of the role of the Constitutional Court. This court is responsible for the overall legality of administrative action and, as noted earlier, will entertain actions challenging either the legality or the constitutionality of administrative subordinate legislation or specific acts. This jurisdiction, which is conferred under the Constitutional Dispositions of 1992, will continue with the coming into effect of the new Civil Procedure Code. The result is likely to be the continuation of two parallel jurisdictions for the judicial review of administrative action, although that exercised by the Constitutional Court will be limited in its scope.

It is difficult to gauge how well the system of judicial review is working in Albania. The inclusion in the new Civil Procedure Code of provisions governing judicial review by the Administrative Courts is a significant advance on the earlier position. The result is a clear and sound legal basis on which judicial review of administration can develop. How the system is working in practice, how often it is invoked by private citizens, and the quality of adjudication in the lower administrative courts are matters on which little information could be obtained.

\subsection{The Prosecutor}

The Prosecutor's Office occupied a key role in the legal structure of the Communist State. In Albania, it was created under the 1981 Act on the Prosecution and exercised a wide ranging jurisdiction to ensure that the various institutions of government acted legally and in the interests of the State. It could take direct action to ensure that administrative authorities, as well as social organisations, discharged their legal obligations. Where direct action failed, the Prosecutor's Office could take matters before the courts, although in practice that was usually unnecessary and rarely done. The Prosecutor's role was closely associated with the interests of the Communist Party and was reformed in 1992, with the result that the Prosecutor now has no public law power to monitor the legality of administrative action. The role of the office is now governed by the Criminal Procedure Code and is confined to investigating and prosecuting 
criminal offences. There are no plans to create a new office to exercise the public law functions previously vested in the Prosecutor.

\subsection{Ombudsman}

The draft Constitution of 1993 does not make provision for an Ombudsman. There is no tradition in Albanian legal history of an Ombudsman, or similar body, although the Prosecutor's Office appears to have performed some of the functions of an Ombudsman. The attitudes amongst officials to the creation of an Ombudsman are mixed, with some in favour and some against, but it is understood that the Ministry of Justice is currently considering the Ombudsman issue, although just how far it has progressed is uncertain.

The draft Constitution does restate the general right of citizens to address complaints and petitions to any administrative or government agency ${ }^{445}$. The tradition of citizens being able to approach government and administration directly with their grievances has roots in Albania, as in other countries of the region. That tradition appears to have lapsed during the communist period, but is now thriving, with the Prime Minister's Department and other government departments being inundated with complaints and requests. These are usually dealt with by the department or passed on to the appropriate authority or agency. The system works on a mainly informal basis and, according to officials involved in it, is only moderately effective, with the lack of adequate resources to investigate complaints and poor organisation being two major obstacles.

Some officials consider these informal ombudsman-like systems sufficient to deal with complaints from citizens. Such devices have little capacity, however, to investigate the complaints and can often do no more than pass them onto the Ministry involved. It is difficult to get a clear picture of how well the special section in the Prime Minister's department, which deals with complaints, is working, or to know how many complaints are being made, but the general view of officials to whom I spoke is that it does not work well. The Parliamentary Commission on Civil Rights, which was created to monitor civil rights issues, also entertains complaints from individual citizens. This is a valuable office, but again it has no capacity to investigate in any systematic manner complaints received; and again it was difficult to get a clear picture of the level of complaints being made and how successfully they were dealt with.

Finally, mention should be made of the Constitutional Court which, in addition to its judicial role as a court of review of constitutional issues, also serves as a kind of informal Ombudsman. It receives complaints from citizens, apparently substantial numbers of complaints, and offers advice where possible. Some of these complaints relate to questions of legality, but the majority appear to be concerned with the sort of issues which would properly be addressed to an Ombudsman, if one existed. Considering the limited resources available to the Constitutional Court, its Ombudsman role is bound to be very limited. It might also be asked whether, in the longer term, the Constitutional Court is a suitable institution for the hearing of these kinds of complaints.

\subsection{Inspectorates and other Forms of General Supervision}

No information was available on the existence and operation of inspectorates and other such forms of supervision.

445 Draft Constitution, Article 23. 


\subsection{Parliamentary Supervision}

The parliamentary tradition in Albania is in its early stages, but since 1991 efforts have been made to create a legislative chamber. This body, known as the People's Assembly, has the usual powers of law-making and supervision of government familiar in other countries. Following the first free elections in 1991, the People's Assembly has taken measures to introduce Rules of Procedure which, amongst other activities, enable it to carry out its supervisory functions in relation to administration. The rules of particular relevance for present purposes are those dealing with the creation in 1992 of standing and ad hoc committees (or commissions as they are more commonly known in Albania).

The commissions are constituted by members of the People's Assembly. Their tasks are wide ranging, including the preparation of draft laws and subordinate legislation, the scrutiny of draft laws or decrees made by other institutions, the study of the effectiveness of laws, and, of particular interest for present purposes, the monitoring and control of the activities of the ministries and other state organisations ${ }^{446}$.

The main function of the standing committee system is in the legislative sphere rather than the administrative. The committees are expected to examine and comment upon draft laws proposed by ministers. The committees do have a supervisory role in relation to the administration, but so far the development of that role has not been a priority for the People's Assembly. However, the structure of the committee system is sound and it is to be expected that the supervisory part will receive more attention in future years.

\subsection{Conclusions and Matters for Consideration}

The main development in Albania towards an effective system of administrative supervision is in the area of judicial review. The creation of an administrative division within the court system is a major step forward and it appears that significant numbers of cases are being brought. The courts are easily accessible, but the dearth of legal advice is a major shortcoming. The Administrative Courts are likely to have an especially important function in administrative supervision, since there is no Administrative Procedure Code and no comprehensive system of internal administrative appeals.

Progress has been made in preparing an Administrative Procedure Code, but it is uncertain when it will be presented to the People's Assembly. It would also be desirable for the administrative courts to have their own procedural law, rather than, as at present, be governed by the Civil Procedure Code. The most pressing issue, however, is to improve the quality of the administrative courts; this urgently requires better training of judges, better organisation and working of the courts, and adequate legal advice for citizens. These of course require resources which at present may not be available.

Apart from judicial review, little progress has been made in Albania towards creating a diverse and comprehensive system of administrative supervision. The emphasis seems to be on a variety of informal mechanisms, some inherited from the past, others springing up in more recent years. Such informality may be compatible with other aspects of the Albanian social structure, and there may be strength in retaining some of them. They should not, however, be seen as a substitute for a well-formed system of more formal and complementary mechanisms and institutions. This should include a comprehensive system of internal administrative appeals, or, even better, a system of first level appeals on the merits to an independent authority.

446 Draft Constitution, Article 14. 
Consideration should be given to establishing an Ombudsman with wide powers to investigate complaints about central and local government. The evidence suggests that such an institution is needed, which would complement existing informal mechanisms. Thought should also be given to forms of inspectorates and commissions to monitor and scrutinise the actions of particular areas of administrative activity. The parliamentary system of committees is adequate, but greater efforts could be made to develop the supervisory aspects.

Following this general discussion, the more specific points to consider include the:

i. scope of jurisdiction of the administrative courts and a specification of the grounds of review of administrative action;

ii. formulation of a code of procedure for the administrative courts;

iii. problem of training for administrative court judges and lawyers;

iv. introduction of an Ombudsman system;

v. review of the various forms of inspectorates and other non-judicial forms of supervision; and

vi. review of the committee system of Parliament to improve its role as a supervisory mechanism.

\section{Comparison and Evaluation}

\subsection{Introduction}

The various kinds of mechanisms, judicial and non-judicial, for supervising the administration were described briefly in the first part of this report. They may be grouped according to the nature of the institution responsible: courts, statutory bodies such as prosecutors and ombudsmen, and parliament. Each is a separate institution which brings to its tasks a certain approach and a particular set of concerns.

A functional analysis also reveals some important differences: the courts adjudicate to determine whether a particular case satisfies the criteria set by law; ombudsmen and related bodies investigate individual complaints but, not being restricted to questions of legality, they can look more deeply into the administrative process; parliament and its committees may also penetrate the details of administration but are normally, although not exclusively, concerned with the more general issues of administration. Now of course these distinctions should not be drawn too strictly and a certain degree of overlap between them is inevitable. Indeed, it might be thought that some overlap is not only inevitable but desirable, so that no one supervisory authority gains exclusive control of any one aspect of administration.

While each form of supervision has its own area of special concern, its own methods, and its own objectives, the feature common to all is that they are independent of and separate from the administrative authorities over which supervision is exercised. The underlying concept is that, no matter how good the administration may be at regulating its own activities, at developing systems of quality control, and providing for an internal appeal structure, the case for external mechanisms is incontestable. It is incontestable on several grounds, some of which were noted earlier but bear repeating. One is the contribution that such mechanisms can make to better quality administration. This is a difficult matter to assess and calls for careful empirical research, but the assumption that external forms of supervision do improve the standard of administration is deeply ingrained in the traditions of administrative law. 
Another related but separate ground for external supervision is the principle of accountability. A basic principle of democratic government is that one authority should be accountable for its actions to another. Even if we were reasonably confident that an authority was making good decisions and conducting itself well in all respects, it would still be important to have mechanisms of accountability, for the very process of showing publicly how an agency is performing its tasks is important. And if we move from the ideal world to the real, where the level of performance is bound to be far from perfect, then mechanisms of accountability may also affect and possibly improve performance.

The third important reason for external supervision derives from the standpoint of the person caught up in an administrative process. The point was made earlier that administration affects rights and, while good quality actions usually mean a high level of respect for rights, the rights perspective should be seen as distinct and important in its own right. It gives a certain point and focus to administration which may easily be lost if good or effective administration becomes the sole test. The idea then is that external mechanisms, particularly those of a more individualised character, help to ensure that primary decisions are properly made and, if they are not, to allow recourse from the primary decision-maker to another authority.

\subsection{Judicial Review}

Turning now to the development of the different forms of supervision in the five countries considered, judicial review of administrative action is the one that has been adopted by all. Several of the countries have enshrined the right to judicial review into their constitution (Bulgaria, Estonia, and Hungary), while others have passed laws adopting the practice (Albania and Poland). In some cases special courts have been created to deal with administrative matters, while in others recourse is sought in the ordinary civil courts. Whether special administrative courts are needed depends on a number of factors, such as the traditions of the country, the expertise of the existing courts, and the availability of resources. Where special administrative courts do not already exist, there is something to be said for beginning with the ordinary civil courts, which will gradually acquire expertise in administrative matters. It may then be sensible at a later point to move towards the creation of special courts.

Whatever court structure is adopted, the principle of judicial review is fairly constant: administrative action should be open to question in the courts on the grounds that the law has been violated or not properly applied. The concept of legality, which lies at the root of this idea, is to be contrasted with the substance or merits of the case, the former being for the court, the latter being left to the judgement or discretion of the decision-making authority. The concept of legality may itself embrace a set of more specific legal principles about the way administrative bodies should act and decide. No attempt, is made, however, in any of the countries to state these principles in legislative form, but it may be assumed that over time the courts will generate a set of doctrines of the kind familiar in many other jurisdictions. In some countries, such as Hungary and Poland, the courts have already generated a significant jurisprudence in these matters.

To have judicial review is one thing, for it to be used with any regularity is another. It may be expected, however, that as lawyers become more familiar with the idea that government can be brought to account in the courts, the practice will slowly spread. The speed with which it does will depend on several factors, but ease of access, cost, and confidence in the independence and standing of the courts will be amongst the more important. The cost and availability of legal advice will also be a major factor in the regularity and success of judicial review. 


\subsection{The Prosecutor}

An office which goes well together with the courts in the exercise of review is the prosecutor's office which generally has public law duties to perform. Each country has this office in one form or another, although Estonia has its own unique office of Legal Chancellor. Albania has removed the public law functions from the Prosecutor whose duties are now confined to the criminal sphere. There is clearly a role for an office whose function is to monitor the legality of administrative action and to take steps to remedy illegality. Whether this is best served by the prosecutor, particularly bearing in mind the much wider and not always benevolent role of that office in earlier periods, is worth considering.

\subsection{Review of the Merits of Administrative Action}

While supervision of the administration through judicial review is developing well, a different attitude prevails in relation to review by a court or court-like body of the merits of acts and decisions. The pattern repeated throughout the five countries is that substantive appeals should be kept within the administrative system itself, the assumption being that if there are mistakes of fact, judgement, or discretion, they are best dealt with by superior administrative bodies. This assumption may be questioned and, in the opening section, several reasons were advanced for a system of merits review by a body independent of the administration. Those reasons may be especially compelling in countries where the administration has been relatively closed and secretive, where a strong identity of interest across government and administration has prevailed, and where the idea of outside scrutiny has been unwelcome.

It should be made clear that to put the case for appeals on the merits is to make a claim in principle rather than for any particular institution or procedure. The principle could be satisfied in a number of ways, ranging from the use of local courts, special administrative courts, or special tribunals. Indeed, in order to overcome fears that an ordinary court would not be sufficiently knowledgeable about or responsive to the specialised administrative aspects of the cases coming before it, the combination of administrative skills and judicial detachment can be an attractive model. Such an approach is well-developed and apparently successful in many countries, including Australia, France, and the United Kingdom. It might be formed by harnessing the extensive forms of internal appeal with some sense of detachment from the administration itself. In short, the provision of judicial appeals on the merits is one matter which all five countries need to consider further.

\subsection{The Place of the Ombudsman}

The ombudsman is another form of supervision which has commended itself to two of the five countries (Hungary and Poland) and is under positive consideration in a third (Estonia). Its use, however, in Hungary and Poland is limited to specific matters concerning constitutional or citizens' rights; that is clearly the most important area needing protection but is by no means the only ends to which ombudsmen may usefully be put. The tendency in some other jurisdictions has been to create a general ombudsman and then a number of special ones. The difficulty with the ombudsman idea is that its appeal in principle is not matched by solid knowledge about its effectiveness in practice.

The truth is that little is known about how well the different forms of ombudsmen perform their supervisory role, whether in securing a better result in the individual case or in stimulating improvements in the general practice of the institution. There may be little doubt about the value of a citizen being able to trigger an investigation by an independent body into the workings of an area of administration, but just how far this device should be extended is uncertain. 
Similar comments may be applied to other forms of inspectorate, boards, and commissions with a supervisory role. The one that stands out in the countries studied here is the Supreme Audit Institution which emphasises the financial and managerial side of administration, although even that office has not been established in all countries. An institution serving that function is now considered in many jurisdictions to be an essential element of good government. All five countries have a range of other supervisory bodies with defined roles and, although some examples have been given, it has not been possible to discuss them in any detail. They do, however, play an important part in ensuring good administration.

\subsection{Parliament and Committees of Parliament}

The final area of supervision is that provided by parliament and the committees of parliament. From the brief descriptions given it can be seen that each of the five countries has the framework for a well-functioning parliament and for a vigorous committee system. It is too early, however, to say whether practice will match promise; the committees offer great potential as mechanisms for scrutinising the administration, but many of them are not yet in operation. The setting-up of the committees is, moreover, only the first step; to get beyond the first step will take time and patience. 